\title{
Gender and Agroforestry in Africa: Are Women Participating?
}

Evelyne Kiptot and Steven Franzel 


\section{龺原 \\ World Agroforestry Centre \\ TRANSFor Agro hives AND LaNDSCAPES}

The World Agroforestry Centre, an autonomous, non-profit research organization, aims to bring about a rural transformation in the developing world by encouraging and enabling smallholders to increase their use of trees in agricultural landscapes. This will help to improve food security, nutrition, income and health; provide shelter and energy; and lead to greater environmental sustainability. We are one of the 15 centres of the Consultative Group on International Agricultural Research (CGIAR). Headquartered in Nairobi, Kenya, we operate six regional offices located in Brazil, Cameroon, India, Indonesia, Kenya, and Malawi, and conduct research in 18 other countries around the developing world.

We receive our funding from over 50 different investors. Our current top 10 investors are Canada, the European Union, Finland, Ireland, the Netherlands, Norway, Denmark, the United Kingdom, the United States of America and the World Bank. 


\section{Gender and Agroforestry in Africa: Are Women Participating?}

Evelyne Kiptot and Steven Franzel 
Titles in the Occasional Papers series aim to disseminate information on agroforestry research and practices and stimulate feedback from the scientific community. Other publication series from the World Agroforestry Centre include Technical Manuals and Working Papers.

Correct citation: Kiptot E. and Franzel S. 2011. Gender and agroforestry in Africa: are women participating? ICRAF Occasional Paper No. 13. Nairobi: World Agroforestry Centre

Published by the World Agroforestry Centre

United Nations Avenue

PO Box 30677, GPO 00100

Nairobi, Kenya

Tel: $+254(0) 207224000$, via USA +1 6508336645

Fax: +254(0)20 7224001, via USA +1 6508336646

Email: icraf@cgiar.org

Website: www.worldagroforestry.org

(C) World Agroforestry Centre 2011

ICRAF Occasional Paper No. 13

ISBN 978-92-9059-293-1

Cover photo: A farmer in Embu, Kenya cutting calliandra fodder (S.Franzel)

Editing/proofreading: Betty Rabar

Design and Layout: Reagan Sirengo and Sherry Adisa

Articles appearing in this publication may be quoted or reproduced without charge, provided the source is acknowledged. No use of this publication may be made for resale or other commercial purposes.

All images remain the sole property of their source and may not be used for any purpose without written permission from the source.

The geographic designation employed and the presentation of material in this publication do not imply the expression of any opinion whatsoever on the part of the World Agroforestry Centre concerning the legal status of any country, territory, city or area or its authorities, or concerning the delimitation of its frontiers or boundaries. 


\section{About the authors}

Evelyne Kiptot is a Senior Research Scientist at the Kenya Forestry Research Institute based at Muguga Regional Research Centre. She holds a PhD in Social Science from Wageningen University, The Netherlands. Her research focuses on innovative extension approaches, gender issues in agroforestry, adoption of improved technologies and incentive measures for conservation.

Steven Franzel is a Principal Agricultural Economist at the World Agroforestry Centre and leads the Centre's Global Research Project on Tree Crop Marketing and Extension. He holds a PhD in Agricultural Economics from Michigan State University USA. A native of the United States, his main research interests include farming systems, participatory research, marketing, extension approaches and natural resource management.

\section{Acknowledgements}

The authors would like to thank Agnes Quisumbing and Diane Russell, our external peer reviewers who provided us with valuable comments. We are also grateful to Meine van Noordwijk for his inputs and for contributing Figure 1. Ramni Jamnadass helped us with the outline early in the process and guided us towards some important references. 


\section{Contents}





Agroforestry practices ................................................................................................................................ viii

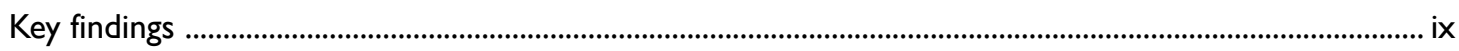

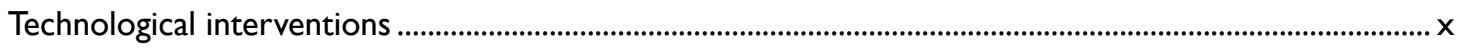

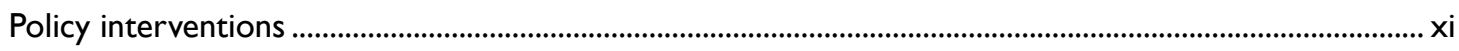

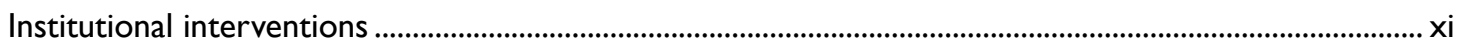

Research needs ...........................................................................................................................................





1.2 Why focus on women and agroforestry in Africa? ........................................................................ 2

2.0 Areas in which women are disadvantaged......................................................................4

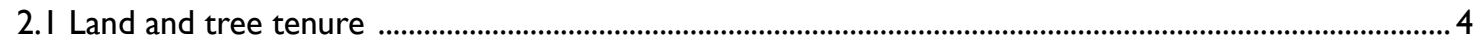

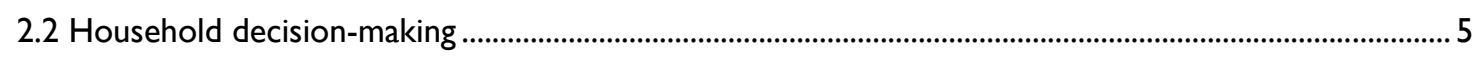

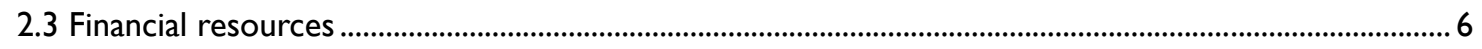



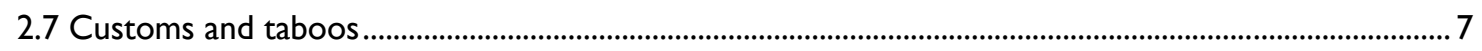

2.5 Education, extension visits, field days and training ......................................................................................

2.6 Lack of appropriate technology ……………………………………………………………………...

3.0 Conceptual framework and research questions ............................................................................. 10

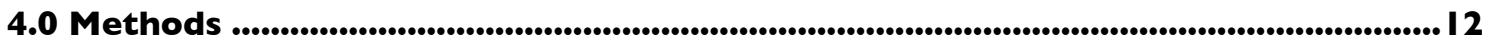



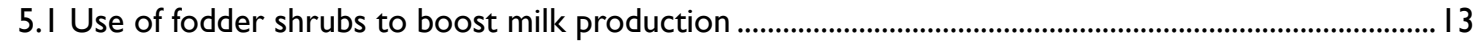

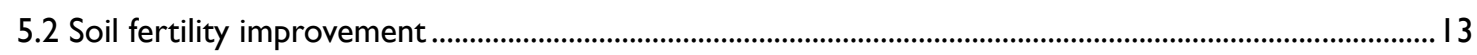


5.3 Indigenous fruit and vegetable production and processing.

5.4 Woodlots

6.0 Women's participation In agroforestry 17

6. I What is the proportion of women participating in agroforestry?

6.2 Are women able to manage agroforestry practices?

6.3 What are women's preferences/rating of various tree species and motivation for planting trees?

6.4 How do women benefit from agroforestry? .26

6.5 Do women have access to agroforestry information?.

6.6 Agroforestry product markets: are women involved?

7.0 How can we promote efficient participation of women in agroforestry with greater benefits accruing to them? ...............................................36

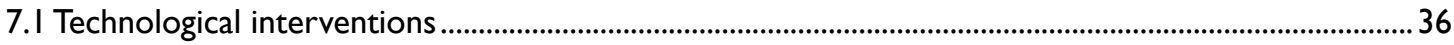



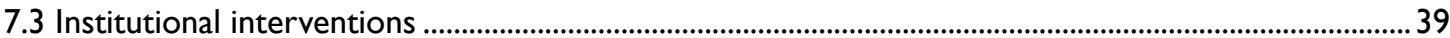

8.0 Conclusion.................................................................................................................................4 I

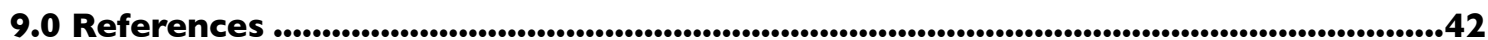




\section{List of tables}

Table I: The resource requirements of options that rural women use to obtain agroforestry products such as fruits, firewood and fodder. 3

Table 2: Men and women decision-making influence on harvesting tree parts in male-headed households in Malawi......5

Table 3: Percentage of respondents in Malawi who collect tree parts without asking for permission from spouse .......... 6

Table 4: Reported number of contacts with extension agents by zone and gender of farmer .......................................... 8

Table 5: Proportion (\%) of male heads of households ( $\mathrm{HHs}$ ) and their wives acquainted with extension agents in Senegal. 8

Table 6: Average level of male heads of households' and their wives' knowledge of natural resources management technologies in Senegal.

Table 7: Types of farmers and groups establishing fodder shrub nurseries in the central highlands of Kenya

Table 8: Numbers of fodder shrubs planted by male and female heads of households in Central Kenya in 2004.

Table 9: Analysis of studies on factors affecting adoption of soil fertility options with gender as a variable.

Table 10: Association between gender of household head and the planting of improved fallows in eastern Zambia (\% in brackets).

Table I I: The range of products being processed by rural women in Southern Africa.

Table I 2: Land size, number of trees and woodlot size by household type in Malawi .21

Table I 3: Responsibility for managing planted trees in Marangu and Mamba districts, Tanzania......

Table I4: Management of planted indigenous trees species by gender in Chivi district Zimbabwe. .22

Table 15: Calliandra fodder adoption in Embu district, Kenya. .23

Table 16: Important tree attributes in tree planting by gender of household head in Malawi .24

Table 17: Primary reasons for establishing woodlots in Malawi by gender of household head... .25

Table I8: Rating trees for major benefits differentiated by gender a in eastern Zambia .25

Table 19: Women's rights to tree harvesting in Western Kenya .26

Table 20: Use of tree products by gender in Western Kenya. .26

Table 2 I: Benefits of fodder shrubs according to farmers in Embu, Kenya and Kabale Uganda .27

Table 22: Fuelwood production from various species of improved fallows determined from 6, I2, 18 months under farmer managed conditions in western Kenya

Table 23: Predicted length of period that firewood harvested from a 0.25 ha plot would last a typical household in .. western.

Table 24: Mean annual production (kg/collector) and annual value of production (CFA/collector) of Ricinodendron heudelotti, Dacryodes edulis and Irvingia gabonensis nuts and fruits in Lekié, Cameroon. 
Table 25: Use and annual revenue of G. africanum in the humid lowlands of Cameroon ................................................3

Table 26: Perceived benefits from woodlots in Malawi by gender of household head .......................................................31

Table 27: Sum total of income from sale of woodlot products in Malawi ..........................................................................32

Table 28: Extension farm visits on calliandra in different gender categories of households in Embu district, Kenya .........32

Table 29: Gender participation in mass awareness activities in Uasin Gishu district, Kenya ..............................................33

\section{List of figures}

Figure I: Interaction between people and trees: key points where gender analysis is needed.......................................... I

Figure 2: Conceptual framework on women's participation in agroforestry...................................................................... 10

Figure 3: Use of soil fertility management options by gender of household head, western Kenya...................................19

Figure 4: Proportion of households collecting different indigenous fruits in Mwekera area, Zambia .................................20

Figure 5:Age (years) categories of G. africanum collectors in central Cameroon ...........................................................20

Figure 6: Involvement of men and women in marketing D.edulis (Safou) in Southern Cameroon .......................................34

Figure 7: Marketing chain of shea butter showing the level at which women are involved...................................................35 


\section{Executive summary}

\section{Background}

This paper presents the findings of a review undertaken on gender and the adoption of agroforestry in Africa. The concept of gender as used in this paper is not about women, but rather as an organizing principle in society, which is used as a process and practice of taking into account the differences between men and women in the course of designing and implementing development projects. The aim is to come up with strategies that challenge gender imbalances, thus ensuring that both men and women are able to make decisions, access resources equitably, hold positions and benefit from development initiatives such as agroforestry. Particular emphasis in this paper is given to women who despite farming remain disadvantaged in the agricultural sector due to cultural, socioeconomic and sociological factors. Such factors include ownership and access to resources, land tenure systems, access to education and extension services, among many others.

The synthesis presented in this paper puts particular emphasis on women's involvement, highlighting their motivation, the benefits they receive and the challenges and successes experienced relative to men. The review examined 104 studies of gender and agroforestry. The coverage of our review is mainly Anglophone Africa and articles in English on Francophone Africa. The review was guided by seven research questions:

- What is the proportion of women participating in agroforestry?

- Are women able to manage agroforestry practices, that is, carry out the needed operations?

- What are women's preferences in relation to tree attributes?

- Do women benefit from agroforestry and how?

- Do women have access to agroforestry information?
- Are women involved in agroforestry product markets?

- How do we promote efficient participation of women in agroforestry with greater benefits accruing to them?

\section{Agroforestry practices}

Agroforestry practices examined include fodder shrubs, "fertilizer trees" for soil improvement, fruit and vegetable production and processing and woodlots. Fodder and soil fertility improvement technologies, based on indigenous practices, were introduced in the last two decades, mainly in East and Southern Africa. Fodder shrubs are protein-rich legumes that are grown along boundaries and pathways or in lines to form terraces, thus reducing erosion and providing firewood. They mature in 9-12 months and can be cut periodically and fed to cows and goats. Three of the most promising "fertilizer tree" options are improved tree fallows (the planting of fast growing leguminous trees or shrubs in rotation with crops), biomass transfer (cutting and incorporating leaf biomass from trees and shrubs as green manure) and mixed intercropping (planting nitrogen-fixing trees that can tolerate heavy pruning in a regular pattern with crops). By providing nutrients to crops, these practices can potentially help farmers improve their soils and incomes, thereby improving food security.

In contrast, woodlots and fruit and vegetable production and processing practices examined are mainly indigenous practices. Fruits and vegetables are consumed fresh or in processed form and are sometimes sold. Woodlots are generally used to produce timber, poles, and fuelwood for both home consumption and sale. The assessment of fruits and vegetables include examples from throughout sub-Saharan Africa while woodlot case studies are from East and Southern Africa. Little or no information concerning gender was available for other agroforestry practices and products such as medicine, gums and resins or exotic fruits. 


\section{Key findings}

\section{What is the proportion of women participating in agroforestry?}

Women's participation is very high in enterprises that are considered to be women's domain, such as indigenous fruit and vegetable products and processing. Indigenous fruits and vegetables are attractive to women because they involve minimal inputs in the form of labour, which women can provide. In the Vitelleria paradoxa (shea) growing region of Benin, $90 \%$ of women are involved in collecting nuts/fruits of the shea tree while in Cameroon, women and children are also the main collectors of the leaves of Gnetum africanum which is used as a vegetable. In Zambia and western Kenya, no significant differences were found between proportions of men and women practising improved fallows. However, there were more women than men using improved fallows and biomass transfer in western Kenya and using fodder shrubs in central Kenya. The findings also show that although women are as actively involved in agroforestry for fodder production, woodlot technology and soil fertility improvement as their male counterparts, their level of participation is low as reflected in the number of shrubs/trees they plant relative to men. Female heads of households planted only half as many shrubs/trees as men, reflecting the fact that their farms were half as large. The lesser involvement reflects women's lack of resources, particularly land and labour, their heavy workload and perhaps also their greater aversion to risk.

\section{Are women able to manage agroforestry technologies?}

Women are frequently responsible for managing trees and as with other agricultural enterprises they do most of the work especially during the initial stages of establishment i.e. planting, weeding and watering. For example, in Uganda, the proportion of households in which women managed fodder shrubs was over $80 \%$. Comparing tree survival rates between men and women is one indicator of the degree to which they are able to manage tree technologies. The results of such analyses are mixed. In Kenya, male-headed households had somewhat higher survival rates for fodder shrubs than women ( $45 \%$ as compared to $31 \%$ ) but the differences were highly variable and not significant. In Eastern Zambia, 47\% of women and only $29 \%$ of men had survival rates for Sesbania sesban of over $75 \%$, six months after planting. For Tephrosia vogelii men had somewhat higher survival rates than women.
What are women's preferences/rating of various tree species and motivation for planting trees?

Men and women often have different objectives for planting trees. Men are usually interested in trees for commercial purposes while women are more inclined to tree products for subsistence use such as firewood, soil fertility improvement, fodder and fruits. This is reflected in the tree attributes that women prefer. In Malawi, women in female-headed households considered trees that grow fast as their first choice, followed by trees with good burning qualities and that produce a lot of charcoal. Men ranked trees that grow straight as their first choice; an indication that timber is their number one priority. Straightness was followed by trees that grow fast. Since both men and women equally use tree products, it is possible to manage tree enterprises for multiple products in a way that both men and women can benefit. A case in point is management and utilization of Grevillea robusta in the central highlands of Kenya, which is grown for both timber and fuelwood. Whereas women often have different planting objectives and evaluation criteria than men, we found remarkably little variation in the way they score different species on different criteria.

\section{How do women benefit from agroforestry?}

Women's rights to tree products are usually limited to products that are considered to have little or no commercial value; men reserve higher value products for themselves. The products that women control are mainly indigenous fruits and vegetables, fodder and mulch. In terms of use, more men than women use timber products. The use of fodder shrubs is beneficial to women in many ways; the income obtained is normally used to pay school fees, general household improvement, fuelwood, fodder and improved nutrition of the family. Access to homegrown fodder and fuelwood from the prunings directly benefits women as it frees up their labour for other productive enterprises. Agroforestry practices for replenishing soil fertility are attractive to women farmers because they involve low inputs but high returns. Apart from the obvious benefit of improving soil fertility, reflected in the high maize yields, they also provide fuelwood and reduce the incidence of weeds such as Striga bermontheca.

Indigenous fruits can provide women with significant income. Women earn US\$ 7-US\$ 36 per annum from shea kernel sales in Benin which may seem small, but it is significant to them because they are able to control it. In Tabora, Tanzania, women are generating income 
through processing and selling of jam, wine and juice from indigenous fruits. They are earning between US\$ 12 to US\$ 30 per week through sale of juice. In Cameroon, income from Gnetum africanum is quite substantial with an average of US $\$ 2,629$ per household per year. Having a woodlot in Malawi saves women 15-180 minutes a day. But the difference in monetary benefits between men and women is significant; male-headed households earn over three times as much income from the sale of woodlot products as do female-headed households. This difference may be attributed in part to the number of trees in a woodlot. Women-headed households on average have half as many trees but only $30 \%$ as much income as men.

\section{Do women have access to agroforestry information?}

Men receive many more extension visits than women and participate in more field days and other extension activities off the farm. The reasons for women's low involvement is the bias of extension workers towards women, socio-cultural barriers limiting communication between male extension workers and women, and women's lack of time to participate in extension activities off the farm. For the few women who are able to access extension services, some lack basic education and therefore their ability to use technical information is limited.

\section{Agroforestry product markets: are women involved?}

Where women are involved in marketing agroforestry products, they are usually confined to the small retail trade while men dominate the wholesale trade. Women traders also receive lower marketing margins than men. This is attributed to the fact that men usually have more stock than women, because they have access to more capital. Just as extension systems are generally biased towards men, market information systems also appear to primarily serve men. Only $20 \%$ of participants in the major market information systems of Kenya and Malawi are women. That women's literacy level is lower than men's presents another important disadvantage in marketing. These disadvantages mean that women fail to benefit equitably from the growing national and international markets.

\section{How do we promote efficient participation of women in agroforestry with greater benefits accruing to them?}

This review provides evidence that agroforestry has the potential to offer great benefits to women across Africa. Women are attracted to agroforestry because of minimal inputs needed, particularly with regard to cash, and the substantial benefits, in terms of food, fuelwood, fodder and other products and services that they get, particularly in times of need. This paper also shows that women face several limitations, which make them unable to get as much benefit from agroforestry enterprises as they should.

Various technical, policy and institutional recommendations on how to promote efficient participation of women in agroforestry with greater benefits accruing to them are proposed in the paper. Recommendations will need to be location-specific and based on the households' needs and circumstances. Household members will need to be involved in the planning, implementation and evaluation of the various interventions.

\section{Technological interventions}

\section{Domestication of important agroforestry species}

Many tree products that benefit women are collected from wild populations in forests, woodlands/ rangelands, parklands or on farms. With the increase in population, some of the products are becoming scarce and women have to walk longer distances. Promoting participatory domestication will therefore enable integration of these valuable species into appropriate farming systems. In addition, various technologies that are socially, culturally and economically acceptable will be developed. The results of such an initiative will be appropriate propagation methods, cultivars that meet a range of market requirements such as fruit with specific size, taste, and maturity periods so that farmers, especially women, can have a year round flow of cash from agroforestry products.

\section{Development of appropriate storage and processing methods}

Many agroforestry products, particularly fruits, have a very short shelf life. It is therefore important to come up with appropriate techniques for improving the postharvest quality of on-tree and off-tree ripened fruits i.e. regulation of harvest time to maximize post-harvest fruit colour and sweetness; improving the artificial ripening under different post harvest incubation regimes and extended shelf life with and without refrigeration. The problem of limited shelf life can also be addressed through processing which ensures supplies for periods of shortage and improves product quality. Where there is market demand for such products, marketing of processed products can also increase women's incomes. Most women still use traditional 
processing techniques that are strenuous and time consuming. Tools and practices to help women reduce the time taken and drudgery of tasks such as dehusking, drying kernels, land preparation and weeding will tremendously free women's time which can otherwise be used in other productive activities. This should be accompanied with capacity building to develop women's business and marketing skills.

\section{Policy interventions}

There are several policy interventions which have been suggested in the paper in order to ensure that women benefit from agroforestry. They are grouped into three key areas; extension services, access to market information and micro-finance.

\section{Access to extension services}

In order to ensure that extension services benefit women, deliberate gender-sensitive interventions need to be put in place. These may include:

- Training more women extension officers, particularly to serve communities that have strong traditions that prohibit male extension officers from interacting with women farmers.

- Targeting women's groups for assistance.

- $\quad$ Finding out from women which periods of the season and day they are most free to meet and holding meetings/field days/seminars at these times.

- Holding separate meetings for men and women.

- Organizing video show sessions for women who are not able to participate in tours.

- Ensuring that at least half of those who participate in any activity are women.

- Ensuring that extension activities address different interest groups i.e. women are more interested in products such as fruits, fuelwood and vegetables while men are more inclined towards trees for timber and poles.

\section{Access to market information}

For women to benefit from market information, deliberate effort must be made by governments and NGOs to specifically target women. Such a programme might involve subsidizing the provision of handsets to women or specialized training on how to use the service. With access to market information, women farmers can greatly reduce losses due to wastage for lack of buyers as they will be able to make informed decisions about when to produce, what to produce, for whom to produce and when and where to sell their produce.

\section{Improving women's access to finance from micro- credit institutions}

For many women to access financial credit, governments need to intervene to encourage the development of rural micro-credit institutions whose regulations are friendly to women. Intervention can be in the form of accepting other forms of collateral other than land such as machinery, furniture and other tangible assets that women may have, strengthening the capacity of existing social organizations such as women groups and linking these groups to financial institutions.

\section{Institutional interventions}

Women producers in sub-Saharan Africa are trapped at the production end of the value chain. So governments, NGOs and the private sector need to intervene by fostering women entrepreneurs, facilitating women to form and strengthen farmers' groups or associations and link them up with markets and industry. By engaging in collective action women would be able to gain a more powerful position in the value chain which is advantageous in several ways: stronger bargaining power, bulk sales, bulk purchases of inputs, ensuring a sustainable supply of products, reduction in transaction costs, attract more and larger buyers, access outside resources, such as extension and development assistance, access to the lucrative fair-trade and other certified markets, and above all be able to contribute to the policy formulation process.

\section{Development of new products}

For women to compete favourably and also have an edge, they must diversify into high value new products such as oil, soap, juices, body lotions, wine, and leaf meal. This can often be done using the same raw materials. 


\section{Research needs}

Several gaps were identified. These gaps if tackled will enable the scientific community, policy makers and development practitioners to understand fully how women across Africa are involved in agroforestry and thereby facilitate the development and implementation of projects that take into account gender issues. Key research areas for further investigation include:

1. Measuring actual income women receive from agroforestry, relative to non-agroforestry enterprises.

2. Assessing the effectiveness and impact of alternative dissemination methods on women's participation and benefits.

3. Determining how different categories of women (e.g. female-headed households and women in male-headed households) benefit from agroforestry
4. Identifying success stories across Africa and assessing the factors that have contributed to their success.

5. Documenting cultural beliefs or taboos regarding tree planting and how they influence adoption of agroforestry by women across the African continent.

6. Determining how to help women to increase their participation in marketing and the amounts they earn from marketing.

7. Determining how gender roles influence women's adoption of agroforestry.

8. Assessing how to help women increase their participation in traditional male tree crops such as coffee, cocoa and oil palm. 


\section{List of abbreviations \& acronyms}

AGRA

ARI

CECI

CFA

CIAT

CIMMYT

CRI

CSIR

CTA

FA

FAO

FC

$\mathrm{FHH}$

FMF

GRID

ha

$\mathrm{HH}$

ICRAF

ICT

IFAD

IFPRI

IIED

ILO

ILRI

JMF

KEFRI

$\mathrm{kg}$

KWAP

$\mathrm{m}$

MA

MC

$\mathrm{MHH}$

MIS

MISTOWA

MK

MMF

NARP

NGO

NRM

ODI

SAPs

SIDO

sms

$\mathrm{t}$

TAWLAE

TSh
Alliance for a Green Revolution in Africa

Agricultural Research Institute

Centre Canadien étude et de Coopération Internationale

Communaute Financiere Africaine franc

International Centre for Tropical Agriculture

International Maize and Wheat Improvement Centre

Crops Research Institute

Council for Scientific and Industrial Research

Technical Centre for Agricultural and Rural Co-operation

Female adult

Food and Agriculture Organization of the United Nations

Female child

Female-headed household

Female managed farms

Global Resource Information Database

hectare

Household

World Agroforestry Centre

Information and Communications Technology

International Fund for Agricultural Development

International Food Policy Research Institute

Internal Institute for Environment and Development

International Labour Organization

International Livestock Research Institute

Jointly managed farms

Kenya Forestry Research Institute

kilogramme

Kenya Wood Fuel and Agroforestry Project

metre

Male adult

Male child

Male-headed household

Management Information Systems

Market Information Systems for Traders' Organizations in West Africa

Malawian kwacha

Male managed farms

National Agricultural Research Project

Non-governmental Organization

Natural Resource Management

Overseas Development Institute

Structural Adjustment Programmes

Small Industries Development Organization

short messaging service

tonne

Tanzanian Women Leaders in Agriculture and Environment

Tanzania shilling 


$\begin{array}{ll}\text { UGK } & \text { Union des Groupments Kiswendsida } \\ \text { UK } & \text { United Kingdom } \\ \text { UNDP } & \text { United Nations Development Programme } \\ \text { UNEP } & \text { United Nations Environment Programme } \\ \text { UNESCO } & \text { United Nations Educational, Scientific and Cultural Organization } \\ \text { UNIDO } & \text { United Nations Industrial Development Organization } \\ \text { UNIFEM } & \text { United Nations Entity for Gender Equality and the Empowerment of Women } \\ \text { US\$ } & \text { United States Dollar } \\ \text { USA } & \text { United States of America }\end{array}$




\subsection{Introduction}

\subsection{Why gender?}

Since the 1995 Fourth World Conference on Women in Beijing, donors, policy makers and development practitioners have pointed out the critical role of gender in development programmes (Doss, 2001; IFAD, 2003; World Bank, 2007; IFPRI, 2007;

Peterman et al, 2010; Quisumbing and Pandolfelli 2010 and Meinzen-Dick et al, 2010). There is a general consensus that gender inequalities in areas such as ownership and access to resources; land tenure systems, education, extension and health have contributed to lower agricultural productivity and higher poverty levels. Given that gender matters in all spheres of production, a lot has been documented on gender issues in agricultural production. However, very little is understood about the role of gender in the adoption of agroforestry. This paper therefore intends to fill the gap by presenting a synthesis of the involvement of women relative to men in various agroforestry practices across sub-Saharan Africa. Gender as used in this paper is an organizing principle in society, which is used as a process and practice of taking into account the differences between men and women in the course of designing and implementing agroforestry. Agroforestry involves the integration of trees and crops or animals and requires access and rights to land, planting material, knowledge, capital and labour
(Figure 1). However, women are disadvantaged due to cultural and socio-economic factors. The purpose of this paper is to examine the participation of women relative to men, highlight gender discrepancies so that strategies that challenge imbalances are addressed, thus ensuring that both men and women are able to make decisions, access resources equitably and benefit from agroforestry. Figure 1 shows the points where gender analysis is required in the sequence of activities from planting to harvesting trees in order to ensure equitable benefits.

The paper begins by justifying why gender is important in development and why a lot of emphasis has been placed on women. This is followed with a highlight on areas in which women are disadvantaged. The third section outlines the problem, conceptual framework and research questions guiding this review. This is followed by a description of methods used, background information of various agroforestry practices examined. The next section examines the research questions highlighting women's involvement, motivation, benefits they receive and challenges faced relative to men. The final section puts forward recommendations on how to promote efficient participation of women in agroforestry with greater benefits accruing to them.

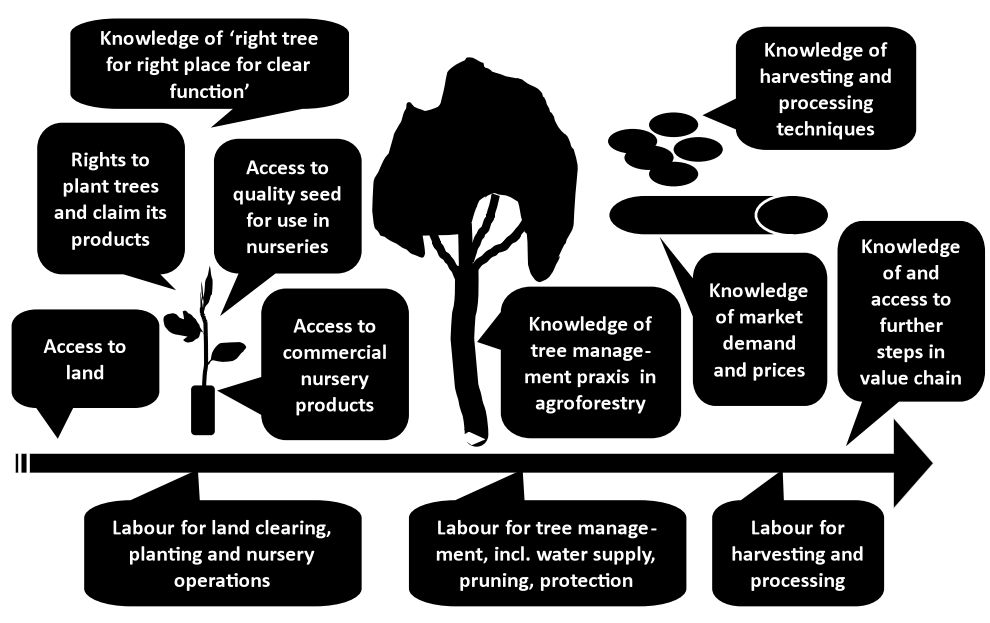

Figure 1: Interaction between people and trees: key points where gender analysis is needed 


\subsection{Why focus on women and agroforestry in Africa?}

Women in Africa play a very important role in agricultural production. This role is widely portrayed in Esther Boserup's now classic book, Women's Role in Economic Development (Boserup, 1970). Boserup, an agricultural economist, used research data from Africa, Asia, the Caribbean and Latin America to highlight women's central positions in the economic life of their societies.

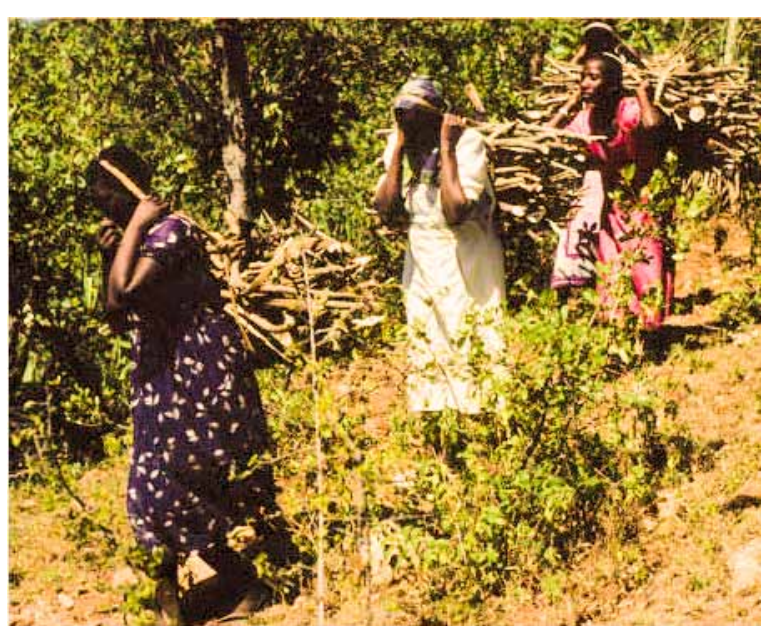

Photo1: Women carrying fuelwood (ICRAF Photo Archive)

Based on her work and that of many others such as Fortmann (1985), Rocheleau (1995); Haddad et al 1997; Quisumbing (1996); Gladwin et al (2001), Quisumbing and Pandolfelli (2010) and Peterman et al (2010) various propositions have since been brought forth:

1. Women play a key role in most production systems.

2. Women's contribution to food security is made in the face of great obstacles.

3. Although women contribute substantially, there is systematic exclusion from the benefits associated with technological change.

4. If women had access to the same resources (e.g., education, farm inputs and labour) as men, food production would be boosted by $10-20 \%$.

5. Despite the key role that woman play, their contribution to agriculture is largely ignored by policy makers.
The focus on women and agroforestry is important for various reasons. Agroforestry as a farming system in which perennial trees and shrubs are deliberately grown on the same land management system as annual crops and/or livestock is a common system of production in Africa. At the centre of this type of farming system are women farmers who are responsible for producing most of the labour. For example, in the smallholder dairy farms of Central Kenya, it has been reported by Maarse (1995) that women provide most of the labour (cutting grass, manure application, feeding animals, milking, fetching water and even selling milk).

Secondly, as a low-cost system that requires minimal inputs and offers a diversity of products and services such as fodder, food, timber, fruits and soil fertility improvement, it offers immense opportunities to women who in most cases cannot afford to adopt high cost technologies due to their severe cash and credit constraints. Such opportunities include increased incomes and sustainable livelihoods. Table 1 shows the resource requirements for four different ways women farmers can supply their families with basic household products: collect them from off the farm, buy them, grow annual crops, or practice agroforestry. Collecting off the farm requires only labour but women's time is scarce and supplies are often located too far from the farm. Moreover, population pressure is reducing off-farm sources of products such as Gnetum africanum, Vitellaria paradoxa and Parkia biglobosa. Purchasing fuelwood, fodder, and fruits is an option but women are acutely cash-constrained. Annual crops are options for providing fodder and a few fruits but require land and labour which are often scarce. Agroforestry has obvious advantages relative to the other three options. It requires relatively little land as trees can be planted around the homestead and on field boundaries. A good example is fodder shrubs in East Africa (Wambugu et al, 2007). Many tree enterprises require relatively little labour, after establishment, e.g., weeding is only necessary during early growth and if trees are mixed with annual crops, then no extra weeding is required. Many trees require no cash inputs or only minimal amounts for the purchase of seed or seedlings, if they can be found.

Third, women are increasingly assuming leadership roles and decision-making in the absence of men in many households. As a matter of fact, Gladwin et al (2001) reports that female-headed households (FHHs) account for $30 \%$ of all rural smallholder households in Malawi while in western Kenya more than half of the households are headed by women (Wangila et al, 1999). In Zimbabwe, it is estimated that over half of rural households in communal areas are headed by 
Table I: The resource requirements of options that rural women use to obtain agroforestry products such as fruits, firewood and fodder

\begin{tabular}{lllll} 
Resource/means & Collect off-farm & Buy & Grow annual crops & Practice agroforestry \\
& \multicolumn{4}{c}{ Resource requirements } \\
Land & 0 & 0 & High & Low \\
Labour & High & 0 & High & Low to Medium* \\
Capital & 0 & High & Low or 0 & Low or 0
\end{tabular}

*Medium if a nursery is required

women (Skapa, 1988). This is due mainly to ruralurban migration of men in search of off-farm income placing the responsibility for obtaining food, fuelwood, fodder and other tree products for the family to women. These women are not only actively engaged in the production of food through agroforestry, but also ensure that agroforestry technologies are spread to other farmers through collective action in tree nursery establishment and sharing the knowledge they have on agroforestry practices within their groups. In central Kenya, for instance, women farmers organized in groups shared Calliandra calothyrsus (a fodder shrub) seed and seedlings with other farmers within their communities (Sinja et al, 2004). Similarly Kiptot et al (2006) found that farmer groups which mainly consisted of women were the most important avenue through which farmers in western Kenya shared seed and knowledge of agroforestry technologies.
Despite their important role in agricultural production, women in Africa remain disadvantaged in the agricultural sector due to cultural, sociological and economic factors. Such factors include limited access to resources and household decision-making. Such resources that are directly linked to agroforestry include land and tree resources, financial credit, extension service, labour and appropriate technology. Furthermore, many African societies have taboos that prohibit women from undertaking certain activities, which may limit their participation in developmental interventions such as agroforestry. These factors are directly linked to agroforestry and have implications on adoption of agroforestry interventions and therefore it is important to highlight them so that they can be addressed by development professionals. 


\subsection{Areas in which women are disadvantaged}

\subsection{Land and tree tenure}

Women in Africa have limited rights to land except in isolated cases. This is because land tenure systems in many parts of Africa grant rights to own and dispose of land to adult males (Place, 1994). While there is tremendous variation across the African continent, the bottom line is that in patrilineal societies, women's rights are often through ties to their husbands and these rights according to Gray and Kevane (2008) may cease to exist upon divorce, widowhood or failure to have a son. Among the Luo of western Kenya, a woman who loses her husband is supposed to be inherited by the deceased's elder brother to ensure that the property of the deceased including land remains in the clan. According to Villarreal (2002), Luo women who refuse to be inherited lose access to land and any other productive resources. Women's rights of transfer of land in patrilineal societies are typically limited: they usually have access of use but not transfer i.e. they cannot sell land or even lend it to others. Among the Luo community of western Kenya, control over land is vested in senior male clan members where sons acquire their rights for their wives at marriage, but do not gain control until their father dies (Scherr, 1995). Even in matrilineal societies such as in western Ghana, women do not possess inheritance rights. Land is transferred from a deceased man to his brother or nephew (sister's son) in accordance with decision of the matrilineal clan (Quisumbing et al, 2001).

Tree tenure is the right to own and use trees. Individuals or households normally retain private rights to all types of trees that they have planted provided that they have rights to the land on which they planted the trees. Different components of agroforestry (such as pollarding, harvesting and felling) may entail different rights of ownership and use among men and women. Both men and women may have separate rights to different parts of the tree (its leaves, branches, fruits, timber or roots) and any benefits from their harvesting, sale or use. Women's access to and control over tree resources is as varied as there are cultures and institutions that govern them. In some societies, whoever plants a tree owns it and has the right to harvest, while in others the man always has an upper hand (Fortmann, 1985). A review of literature reveals that rights over resources such as trees or crops vary significantly over time, type of tree species and among different communities and is usually negotiable. Women's rights in Africa as far as trees are concerned are mostly confined to byproducts of men's trees. These byproducts are considered secondary with no significant economic importance. But the moment the 'byproducts' become valuable they are usually taken over by men.

According to Rocheleau and Edmunds (1997), wives among the Luo community of western Kenya have rights of collection and use of fruits, but are restricted from harvesting fuelwood of high value timber trees such as Markhamia lutea and Albizia spp. A species such as Sesbania sesban, which is good for fuelwood and soil fertility improvement is considered a woman's tree and therefore they have the authority to plant, manage, use and dispose of as they please. This is also common among the Luhya community of western Kenya who are neighbours to the Luo (Bradley, 1991). Among the Akamba community of eastern Kenya, Rocheleau and Edmunds (1997) report that tree planting and felling have been primarily a male's domain, while women have enjoyed use and access rights to fodder, fuelwood, fiber, fruits and mulch. Tree products such as charcoal, logs, timber, large branches and poles are considered a male domain.

Nwonwu (1996) notes that among the Ibo of southeastern Nigeria, women own economic trees such as the palm oil as a reward from their husbands for their ability to bear children. For every child born, a palm tree is set aside in the communal farmland to mark the arrival of the child. Mothers continue to harvest the palm on behalf of their young children. The male child will take possession of the tree when he reaches adulthood and passes it on to his wife when he eventually marries. Domesticated fruit trees of commercial and economic importance such as mangoes, papayas and oranges are known to be planted and harvested by both men and women in many parts of Africa (Okigbo, 1980). There are however certain fruit trees that are considered to be traditionally feminine crops because they are considered subsistence and grown around the homestead. Bush mango (Irvingia macrophylla), bread fruit (Treculia africana), and oil bean tree (Penthacletra macrophylla) are planted and processed by women in West Africa (Nwonwu, 1996). In parklands of West Africa, women are responsible for the collection and processing of Vitellaria Paradoxa (shea nut) and therefore men normally retain these trees for their wives (Schreckenberg, 2004). 


\subsection{Household decision- making}

Gender-related decision-making which is linked to intrahousehold resource allocation is an important determinant of the adoption of technologies by both men and women. There is considerable evidence that women's decision-making power in households is limited to byproducts of men's trees, subsistence crops that have low returns on labour and those that involve less advanced technologies (Chikoko, 2002; Abbas, 1997; Rocheleau and Edmunds, 1997). Furthermore, women normally have obligations to provide labour for male-controlled household fields (Abbas, 1997). According to Chavangi (1994), the general understanding in western Kenya among the Luhya community for instance is that the husband, as the head of household, has overall control of the household resources and in that capacity, everything in the household is viewed as belonging to him. The wife is therefore expected to seek the opinion of her husband and ultimately his consent before going ahead with any plans that may bring about any changes in the allocation of household's resources. In theory, joint decision-making between man and wife is implied, but the wife is seen to be making decisions that affect subsistence crops, fruit collection, and the use of women's trees. In a study in western Kenya where ICRAF was testing hedgerow intercropping in the early 1990s, decision-making among the Luo and Luyha was not rigidly divided along gender line, but men had significant decision-making power especially in cases where there was conflict in the use of resources, that is, how much of the pruning to use as mulch and fodder (David, 1998). Similarly, in southeastern Nigeria, the same trend was observed among the Igbo community (Francis and Attah-Krah, 1989). In some communities such as the Akamba of eastern Kenya, women have more rights although male heads of households are the main decision makers on matters of tree planting as recorded in slightly less than $50 \%$ of the cases studied by Muok et al (1998). Cases where both husband and wife made decisions about tree planting were about $20 \%$ while $14 \%$ of decision-making was made by women who either had husbands working away from home or were widows.

Regarding who makes decisions on harvesting of tree products, Chikoko (2002) noted that women's decision power in Malawi was dependent on the part of the tree harvested. Women's influence on harvesting decisions decreases as decisions move from twigs to the trunk with combined frequencies of influential and very influential showing that $67 \%$ of women were influential in making decisions on harvesting twigs, $64 \%$ for branches, $57 \%$ for trunks. The trend contrasts to men's decision-making power with their influence increasing as decisions move from twigs to the trunk (Table 2).

Regarding whether men and women needed to seek permission from their spouses before harvesting any tree product, Chikoko (2002) noted that the majority of men (over 92\%) had full, non-restricted access to the woodlot and did not ask for permission from their wives to harvest any part of a tree. Women, on the other hand, have autonomy over collecting smaller parts of trees (twigs and branches) which are normally used for fuelwood without having to ask for permission from their husbands (Table 3). More women are required to ask for permission from their husbands

Table 2: Men and women decision-making influence on harvesting tree parts in male-headed households in Malawi

\begin{tabular}{|c|c|c|c|c|c|c|}
\hline \multirow[t]{4}{*}{ Degree of influence } & \multicolumn{6}{|c|}{ Part of tree mentioned } \\
\hline & \multicolumn{2}{|c|}{ Twigs } & \multicolumn{2}{|c|}{ Branches } & \multicolumn{2}{|c|}{ Trunks } \\
\hline & \multicolumn{6}{|c|}{$\%$ of respondents } \\
\hline & Women & Men & Women & Men & Women & Men \\
\hline No influence & 4.8 & 6.9 & 4.8 & 7.1 & 8.2 & 3.8 \\
\hline Not very influential & 17.5 & 24.1 & 19.0 & 21.4 & 21.3 & 3.8 \\
\hline Equal influence & 11.1 & 24.1 & 12.7 & 28.6 & 13.1 & 30.8 \\
\hline Influential & 23.8 & 13.8 & 27.0 & 10.7 & 34.4 & 11.5 \\
\hline Very influential & 42.9 & 31.0 & 36.5 & 32.1 & 23.0 & 50.0 \\
\hline
\end{tabular}

NB:Women's decision-making power scores are from women's responses $(n=65)$

Men's decision-making responses were obtained from men's responses $(n=4 I)$ 
Table 3: Percentage of respondents in Malawi who collect tree parts without asking for permission from spouse

\begin{tabular}{|c|c|c|c|}
\hline \multirow[t]{2}{*}{ Collects without permission } & \multicolumn{3}{|c|}{ Part of tree } \\
\hline & Twigs & Branches & Trunks \\
\hline \multicolumn{4}{|l|}{ Husband's response $n=41$} \\
\hline Husband & 100 & 100 & 97.2 \\
\hline Wife & 80 & 70 & 42.5 \\
\hline \multicolumn{4}{|l|}{ Wife's response $n=65$} \\
\hline Husband & 90.3 & 88.7 & 84.1 \\
\hline Wife & 75 & 69.9 & 57.4 \\
\hline
\end{tabular}

Source: Chikoko (2002)

with increasing size of the part of the tree.

Various reasons cited by Chikoko (2002) were given as to why women asked for permission from their husbands. Similar reasons given by both men and women included family protocol, husband's plans or uses for the tree, the woman may cut wrong trees or parts, to instruct the woman on what, where and how much to collect, for the husband to keep track of harvesting activities, or she may get friends to harvest fuelwood from the woodlot. For the few men (about $8 \%$ ) who asked for permission to get the trunk they said they did so either because the wife owned the woodlot or out of respect for the wife.

\subsection{Financial resources}

Women face difficulties in accessing credit to buy farm inputs and other assets to meet basic household needs. Access to financial resources such as credit, is linked to women's access to property, land, literacy rates, lack of information and socio-cultural barriers (ILO, 1998; Quisumbing and Pandofelli, 2010). According to World Bank (2007), 40\% of women in Kenya are smallholder farm managers, yet they receive less than one percent of agricultural credit. IFAD (1985) reported that in Sierra Leone $7 \%$ of loan recipients are women while in Malawi they were about $6 \%$. This has direct implications on the rate of adoption of improved technologies. World Bank (1989) reported that over half of the women in Meru and Murang' a areas of Kenya said lack of cash hindered them from using improved varieties of seeds, fertilizer and other inputs. To overcome this limitation, women in many parts of Africa have devised other innovative ways of getting credit such as joining informal saving clubs popularly known as 'merry-go-rounds' or chamaa in Kenya
(Kiptot, 2007) and tontines in Senegal (Gerin, 2006). Unfortunately these clubs may not provide them with enough capital to start big income generating projects. Furthermore, Kabeer (2005) and Quisumbing and Pandofelli (2010) caution that access to financial credit alone may not be enough if women invest in microenterprises that have low returns.

\subsection{Labour}

Although labour is the only resource that women in many parts of Africa have at their disposal, femaleheaded households are disadvantaged in that they face greater difficulty obtaining male labour needed for particular tasks such as land preparation and tree pruning (Swinkels et al, 2002). In many parts of Africa, men have claim over women's labour, but women do not have similar claim over men's labour; in fact females in male-headed households in certain parts of Africa are obligated to work on male-controlled fields which take precedence over their own (Abbas, 1997).

A similar problem faced by women is difficulty in obtaining sufficient labour during peak labour periods (Carloni, 1987). These vary depending on the farming system, but the times of land preparation, weeding and harvesting are usually the most acute. Not only are poor women often unable to obtain needed male labour; they are also unable to hire labour due to lack of cash. Further exacerbating their crop performance and well-being, peak labour periods often coincide with periods of acute food shortages, when women are weakest and may have to work as labourers on other people's farms to feed their families. Their inability to mobilize labour for managing their farms in an optimal fashion may put them on a downward cycle of poor yields, inadequate resources for managing their farms, and further reductions in yields. 


\subsection{Education, extension visits, field days and training}

Several studies have shown that women have less access to agricultural extension than men. In Malawi for instance $19 \%$ of women had access to extension compared to $81 \%$ of men (Gilbert et al, 2002). In Ethiopia, the figures were $20 \%$ for women compared to $27 \%$ for men (World Bank and IFPRI 2010). In Uganda, women had 1.13 contacts with extension compared to men's 2.03 (Katungi et al, 2008). Figures released by UNEP/GRID-Arendal (2008) show that although $70 \%$ of agricultural work in Benin and Zimbabwe is carried out by women, fewer than $10 \%$ of extension staff is female. In addition, most of the extension services are focused on cash crops (men's crops) rather than food and subsistence crops, which are considered to be women's domain. These statistics are confirmed by a study carried out by CIMMYT (1998) and reported by Morris and Doss (1999) on how gender affects the adoption of innovations in Ghana; they found that on average, women reported fewer contacts with extension agents, and a large proportion of women reported no extension contacts at all (Table 4).

Another study reported by Moore et al (2001) on differential access to technical information on natural resource management (NRM) among men and women in Senegal, showed that contact with extension staff increases farmers' knowledge of improved technologies. Male agents contacted household heads who were men, while their wives benefited more from women extension agents (Table 5). The study by Moore et al (2001) found that men were more knowledgeable than their wives in composting and forestry technologies (Table 6). The results for knowledge on nursery techniques were mixed, with women in the southern zone having more knowledge than men. This disparity is attributed to the fact that women in this region are traditional rice producers.

\subsection{Lack of appropriate technology}

Most women in sub-Saharan Africa use manual labour due to lack of suitable household and farm processing technology. For instance, women in Burkina Faso use three to four days to prepare P. biglobasa fermented seeds while extraction of shea ( $V$. paradoxa) nut butter is a physically strenuous and time consuming exercise (Teklehaimanot, 2004). Technologies to improve crop production are also limited for women farmers. The use of animal traction is known to substantially reduce the demand for women's labour yet many lack access to this valuable piece of technology. Watson et al (undated) found that more male-headed households (80\%) owned a plough compared to about $62 \%$ of female-headed households in Zimbabwe.

\subsection{Customs and taboos}

Cultural beliefs influence agroforestry adoption. They include ritual and ritual prohibitions against planting or using certain trees, where trees may be planted and limitations on who may plant trees. It is difficult to make any generalization about cultural norms and customary rulings because they vary for different people in different areas. These beliefs are however, powerful determinants of people's actions, and often hold more local influence than rules and formal legislation set by national government.

According to Chavangi (1994), tree planting activities in western Kenya are dominated by men and it has been effectively sustained through well manipulated cultural practices (taboos). Just as ownership of land is by custom denied to women, ownership of trees is also denied to women. To ensure that this vital customary requirement is sustained, certain reasons are advanced as to why women are not allowed to plant trees. Most of the reasons may scare women from active participation in tree planting activities thus preserving male dominance. The reasons advanced in western Kenya to inhibit women from planting trees according to Chavangi (1994) include:

- If a woman plants a tree, she could become barren.

- If a woman plants a tree, her husband could die.

- If a woman plants a tree, the action is viewed as direct challenge to the husband's supremacy in the household. It is seen as seeking to claim equality in the home and such an action could result in divorce.

- During the construction of a house, wood from a tree planted by a woman could not be used. It follows therefore that as one of the major uses of trees is for construction purposes, women were prohibited from planting trees so as to rule out the possibility of wood from such trees being used for the construction of a house.

Among the Ibo of southeastern Nigeria, Nwonwu (1996) reports that it is regarded as an abomination if women climb certain types of trees such as the oil 
palm, coconut palm or raffia palm. These taboos and prohibitions were a great hindrance for many women in the past, but with modernization and Christianity taking root in addition to a high rate of male migration to urban centres in search of jobs, women are increasingly going against taboos to plant and take care of trees. Ipara (1993) reports that of the 25\% of women who planted trees in western Kenya, none reported any repercussions either from men or from the gods.

Table 4: Reported number of contacts with extension agents by zone and gender of farmer

\begin{tabular}{|l|ll|ll|ll|l|l|} 
No. of contacts & \multicolumn{2}{|c|}{ Coastal Savannah } & \multicolumn{2}{|c|}{ Forest } & \multicolumn{2}{c|}{ Transition } & \multicolumn{2}{c|}{ Guinea Savannah } \\
\cline { 2 - 7 } & Male & Female & Male & Female & Male & Female & Male & Female \\
0 & 26 & 19 & 81 & 38 & 27 & 15 & 39 & 0 \\
$1-3$ & 14 & 2 & 21 & 17 & 11 & 3 & 24 & 2 \\
$4-7$ & 6 & 1 & 11 & 0 & 2 & 3 & 9 & 0 \\
$>8$ & 14 & 2 & 19 & 2 & 1 & 1 & 10 & 0 \\
\hline Total & 60 & 24 & 132 & 57 & 41 & 22 & 82 & 2 \\
\hline
\end{tabular}

Source: CRI/CIMMYT (1998) as reported by Morris and Doss (1999)

Table 5: Proportion (\%) of male heads of households $(\mathrm{HHs})$ and their wives acquainted with extension agents in Senegal

\begin{tabular}{|l|ll|ll|ll|} 
& \multicolumn{2}{|l|}{ Team Leader } & \multicolumn{2}{|l|}{ Forestry agent } & \multicolumn{2}{|l|}{ Women's agent } \\
& Wife & HHs & Wife & HHs & Wife & HHs \\
\hline & & & \multicolumn{2}{|l|}{ Percentages } & & \\
Northern Zone & 10.2 & 36.5 & 46.1 & 47.1 & 20.0 & 24.4 \\
Fleuve & 11.0 & 52.7 & 44.0 & 63.7 & 20.0 & 24.2 \\
Ferlo & 7.3 & 52.3 & 46.8 & 78.0 & 13.2 & 13.8 \\
Niayes & 9.0 & 49.3 & 38.8 & 50.7 & 62.7 & 58.2 \\
Peanut Basin & 10.5 & 29.5 & 47.1 & 38.7 & 23.7 & 15.3 \\
Southern Zone & 26.3 & 52.1 & 36.9 & 54.3 & 13.2 & 5.9 \\
Southern forest & 26.0 & 53.4 & 35.6 & 52.7 & 12.3 & 5.5 \\
Southeast & 27.4 & 47.4 & 37.6 & 60.0 & 16.7 & 7.4 \\
\hline
\end{tabular}

A team leader is in charge of extension agents with different expertise based at Rural Extension Service Centres (CERP). The forestry agent is responsible for forestry activities while the women agent is responsible for home economics and all other women's productive activities.

Source: Moore et al (200I) 
Table 6: Average level of male heads of households' and their wives' knowledge of natural resources management technologies in Senegal

\begin{tabular}{|l|ll|ll|ll|} 
& \multicolumn{2}{|l|}{ Nursery techniques } & & \multicolumn{2}{l|}{ Composting } & Forestry Practices \\
& Wife & HH & Wife & HH & Wife & HH \\
& & & Mean scores* & & & \\
& & & & & & \\
Northern Zone & 1.02 & 1.10 & 0.18 & 0.78 & 2.60 & 3.18 \\
Fleuve & 1.20 & 1.29 & 0.01 & 0.76 & 2.59 & 3.14 \\
Ferlo & 0.95 & 1.12 & 0.19 & 0.83 & 2.95 & 3.97 \\
Niayes & 1.27 & 1.45 & 0.22 & 1.04 & 3.06 & 3.16 \\
Peanut Basin & 0.97 & 1.03 & 0.20 & 0.75 & 2.52 & 1.19 \\
Southern Zone & 1.55 & 1.19 & 0.46 & 0.52 & 1.38 & 1.92 \\
Southern forest & 1.75 & 0.89 & 0.51 & 0.52 & 1.31 & 1.85 \\
Southeast & 0.87 & 1.12 & 0.31 & 0.53 & 1.19 & \\
\hline
\end{tabular}

* Each technology was measured on a self-reported three-point scale: do not know about it, know about it but do not use; know and use the technology. $\mathrm{N}=694$ paired responses.

Source: Moore et al (200I) 


\subsection{Conceptual framework and research questions}

In the previous section, it has been argued that agroforestry has the potential to offer great benefits to women. However, their participation is hampered by limited access to resources such as land, capital and labour. Additional constraints include limited access to extension services, lack of appropriate technology and taboos that prohibit women from planting or using certain trees (Figure 2). Conceptually, this study takes the view that despite the above limitations, women are increasingly exercising their user rights to land and tree resources, and are participating in agroforestryrelated activities across Africa. Participation is the key concept explored in this study. It is viewed from a broader perspective involving the "who" and the "how" of participation (Cohen and Uphoff 1980). The "who" examines participation of women relative to men. The "how" describes various mechanisms through which participation takes place, which includes the form, extent and effects. The form of participation includes establishment of nurseries, planting seedlings, management (watering, weeding, protecting against grazing and application of manure), collecting fuelwood and fruits, processing and marketing. The extent examines the proportion of women's participation versus men's in agroforestry in addition to their participation in product markets and access to agroforestry information. The effects of participation are the benefits that accrue from agroforestry and these may include products such as fuelwood, fruits, vegetables, timber, and poles. In order to enhance the participation of women, various interventions are proposed. They are grouped into three: a) technological (improved cultivars, development of post harvest storage methods, appropriate agricultural and processing equipment and development of new products), b) policy (access to financial credit, extension, markets, market information) and c) institutional interventions (facilitation by NGOs and government and strengthening of farmer groups/ associations and linking them to market and industry).

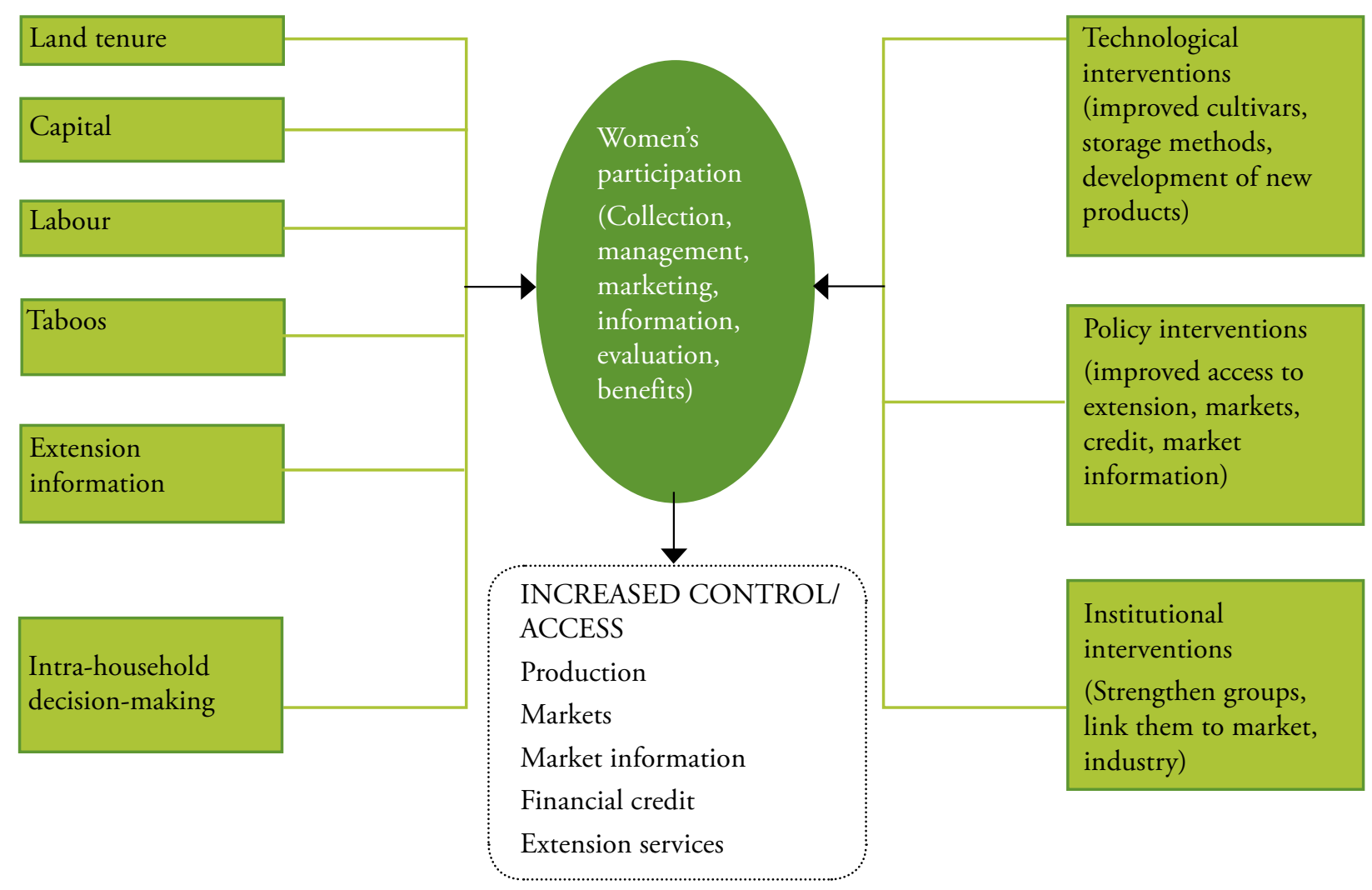

NB. Resources and conditions on the left hand side may promote or hinder participation. Interventions on the right hand side are intended to promote women's participation in agroforestry

Figure 2: Conceptual framework on women's participation in agroforestry 
It is envisaged that these interventions may uplift women from the lower end of the value chain to a position where they have more access to extension services, credit and market information in addition to control over production, marketing and processing thus improving the benefits that accrue to them (Figure 2).

Seven questions based on the conceptual framework (Figure 2) were formulated to evaluate women's participation in agroforestry in relation to men:

1. What is the proportion of women participating in agroforestry?

2. Are women able to manage agroforestry technologies, that is, carry out the needed operations?
3. What are women's preferences in relation to tree attributes?

4. Do women benefit from agroforestry and how?

5. Do women have access to agroforestry information?

6. Are women involved in agroforestry product markets?

7. How do we promote efficient participation of women in agroforestry with greater benefits accruing to them?

Agroforestry practices examined include fodder production and utilization, fruit and vegetable production and processing, soil fertility improvement and planting of woodlots. 


\subsection{Methods}

The paper is based on a review of 104 publications (books, refereed journals, conference proceedings and unpublished reports). Searches were done using Google Scholar to find publications on gender and agroforestry. Library collections from the World Agroforestry Centre and Kenya Forestry Research Institute were also used. There were, however, very few studies published on gender and agroforestry and therefore we had to look for adoption studies in which gender was discussed. Other topics that we used to identify gender issues are articles on gender and credit in addition to microfinance. We also followed leads from publications on gender and forestry, and gender and land tenure to identify references related to gender and agroforestry.
There were however some shortcomings. The coverage of our review was limited to articles published in English, so there was a bias towards Anglophone Africa. Moreover, the practices assessed were more widely promoted in east and southern Africa. Another shortcoming is that many of the studies had very small sample sizes which made it very difficult for us to generalize from them. Third, due to lack of data on gender issues on other agroforestry practices, we were restricted to fodder production and utilization, soil fertility management, fruits and vegetables production/ processing and woodlots. There may be other publications, such as grey literature that may have been left out because we could not access them using electronic engine searches. 


\subsection{Agroforestry Practices}

This section presents background information about agroforestry practices assessed in this paper. In the agroforestry literature, a practice is sometimes used synonymously with a technology. However, this paper is using the word 'practice' since it is broader. A practice refers to a specific land management operation on a farm or other management unit and usually consists of various arrangements of agroforestry components both in space and time (Nair, 1989). The practices discussed are grouped according to the products and services they generate. The first two groups, improving milk production and soil fertility, involve mostly recently introduced practices (over the last 20 years) and focus on east and southern Africa. Indigenous fruit and vegetable production and processing involve mostly traditional practices and include examples from east, southern and western Africa. The last set, woodlots for producing fuel and construction wood, involves examples from east and southern Africa. The practices were selected because information was available on gender issues. Little or no information was available for other agroforestry practices and products, e.g., for medicines, for gums and resins or for exotic fruits. Findings are categorized by practice because most studies dealt with a particular practice. But in reality, the concept of a practice is sometimes not clear, as when a particular agroforestry arrangement has multiple products. For example, leafy biomass may provide fodder and soil fertility and woody biomass provides fuelwood.

\subsection{Use of fodder shrubs to boost milk production}

Most livestock in Africa are found in mixed smallholder farms characterized by their small size, limited production resources and low income level of farmers. The shortage of fodder coupled with low quality feeds is the greatest constraint to improving livestock productivity and reproductive performance, especially during the dry season (Winrock International, 1992). Despite the demonstrated advantage of the use of herbaceous legumes as high quality fodder, their use has not been widely adopted by small-scale farmers. The low adoption has been partly attributed to the scarcity and high cost of the legume seed (Paterson et al, 1998). In contrast, there has been considerable adoption of fodder shrubs in the highlands of East Africa to provide the much-needed protein to dairy cows (Franzel and Wambugu, 2007).

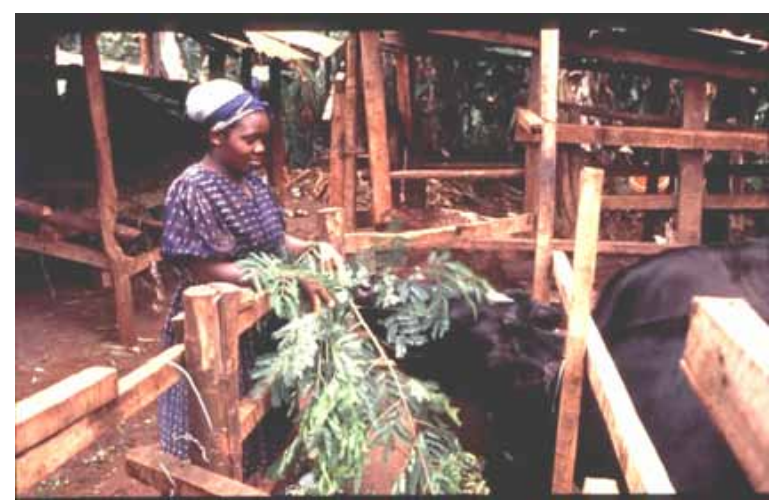

Photo 2: A farmer in Embu, Kenya, feeds her cow with calliandra fodder (A. Njenga)

ICRAF and a range of national research and development partners in Kenya, Uganda, Rwanda, and Tanzania developed fodder shrub practices in the 1990s. The shrubs are easy to grow, capable of withstanding repeated pruning and compete very little with food crops. The plants mature in 9-12 months and are then ready to be cut periodically and fed to cows and goats. The shrubs are grown along boundaries and pathways or in lines to form terraces, thus reducing erosion and providing firewood.

The development and extension of fodder shrubs has involved some 224 partner organizations in Kenya, Uganda, Rwanda, and Tanzania. Nine fodder shrub species are presently available for extension in environments ranging from the hot, humid coastal lowlands to semi-arid tropics and mountain ecosystems up to 3,000 metres. Calliandra calothyrsus is the most commonly grown species. By 2005, over 200,000 farmers in East Africa had planted the shrubs (Franzel and Wambugu, 2007).

\subsection{Soil fertility improvement}

One of the most serious constraints to the sustainability of agriculture in sub-Saharan Africa is declining soil fertility. In the past, African farmers managed soil fertility on their farms by fallowing their land. However, as the population increased, fallowing of land reduced, with many farmers adopting intensified land use practices that required fertilizers to replenish nutrients. Many African states subsidised fertilizer prices to stimulate fertilizer application, but these subsidies were subsequently removed. The removal of such subsidies, due to structural adjustment 
policies (SAPs), has substantially increased costs for many farmers who now cannot afford to use fertilizers (FAO, 2001). This trend has exacerbated the problem of declining soil fertility, leading to reduced crop productivity (Cooper et al, 1996; Sanchez et al, 1997).

To address these challenges, scientists have in the past two decades experimented on low cost agroforestry options for soil fertility replenishment. Three of the most promising options are the use of improved tree fallows, biomass transfer and mixed intercropping (Sanchez et al, 1997; Sanchez, 1999; Niang et al, 1996; Ajayi et al, 2003; Thangata and Alavalapati, 2003). Improved tree fallows are the deliberate planting of fast growing leguminous trees or shrubs in rotation with crops. Biomass transfer on the other hand is a technology where biomass from shrubs or trees grown on or off the farm is cut and incorporated into the soil as green manure when planting crops. Mixed intercropping involves planting nitrogen-fixing trees that can tolerate continuous and heavy pruning, in a regular pattern with crops such as maize. Two rows of maize are sown between tree rows with lopping done twice during each season and the leaves are incorporated in the soil where maize is planted. By providing nutrients to crops, these technologies can potentially help farmers improve their soils and incomes, thereby improving food security.

Since the late 1980s, the World Agroforestry Centre and partners in Malawi, Zambia and western Kenya have developed and disseminated several agroforestry options for soil fertility management. The number of farmers using fertilizer trees in southern Africa reached 180,000 during the 2002/2003 season (Ajayi et al, 2005). In western Kenya, the number of users has been somewhat disappointing due to a number of reasons, e.g. small farm sizes (Kiptot et al, 2007).

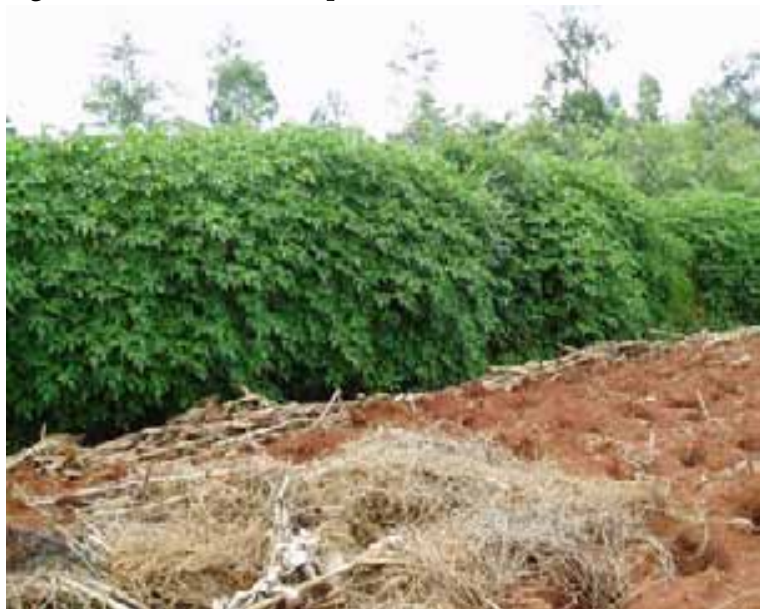

Photo 3: Tithonia diversifolia hedge for biomass transfer in western Kenya (E. Kiptot)

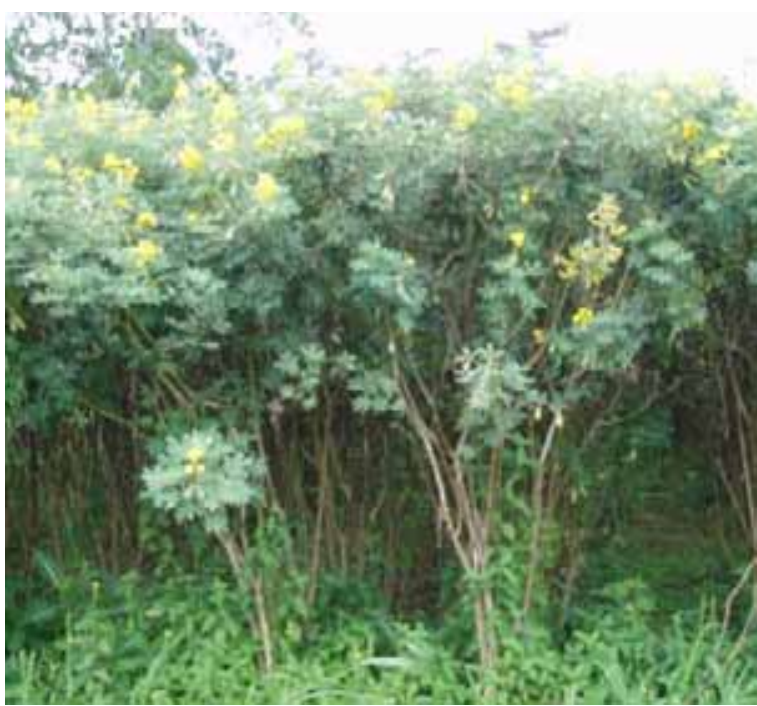

Photo 4: Improved fallow of Crotolaria grahamiana (E.Kiptot)

\subsection{Indigenous fruit and vegetable production and processing}

Food insecurity, poverty and malnutrition are some of the major challenges that face sub-Saharan Africa. In Nigeria for example, $70 \%$ of the population lives below the poverty line (Bird and Dickson 2005), while in Cameroon the figure is $40 \%$, rising to $55 \%$ in the forest region (Schreckenberg et al, 2006). In addition to poverty, Africa is facing a serious problem of not being able to feed its people (FAO, 2006). As a matter of fact, it is estimated that $60-80 \%$ of rural households in Malawi, Zambia and Mozambique run out of food for as long as three to four months per year (Akinnifesi et al, 2004). Those most at risk are women and children. Through the ages, most of these people have relied on wild plants, which come in handy during periods of famine. Wild plants provide fruits, medicine, vegetables, spices, etc. In a survey conducted in Malawi, Zambia and Zimbabwe, $26-50 \%$ of households confirmed that they reduced vulnerability by collecting indigenous fruits from wild plants (Akinnifesi et al, 2006).

Several studies have acknowledged the fact that indigenous fruits are rich in nutrients in addition to having the potential to generate income for many rural households. In Zimbabwe, for example, wild fruit trees represent about $20 \%$ of the total woodland resource use by rural households (Campbell et al, 1997) with women and children being the main beneficiaries. They collect, consume in both fresh and processed form, sell and use the proceeds to buy food and other 
household goods (Ramadhani, 2002; Mithofer, 2004). In west and central Africa region, indigenous fruits are important components of the local diets; Dacryodes edulis, for example, is a staple food for 3-4 months of the year with palm oil being the main cooking fat. As one moves to the Sahel, it is replaced by shea butter (Schreckenberg et al, 2006). The shea tree ( $V$. parodoxa) not only provides edible fruits and nuts to make butter but also fodder for livestock. In eastern Africa, households in dry areas consume indigenous fruits such as $V$. parodoxa, Tamarindus indica, Vitex doniana, Adanisonia digitata (Matig and Chikamai, 2009; Muok et al, 2001).



Photo 5: A woman selling D.edulis in Cameroon (ICRAF Photo Archive)

Despite the importance of indigenous fruit trees and vegetables in the livelihoods of rural people in Africa, they are seldom planted by farmers, because they are perceived as nature's gifts. Massive deforestation is reducing the availability of these valuable resources. In view of this, ICRAF and its national partners have in the past decade been undertaking research aimed at domesticating priority fruit tree species in west, eastern and southern Africa to enhance the potential of these trees for increasing the income and food security of rural people. Tremendous progress has been made with domestication efforts in southern Africa focusing on species such as Sclerocarya birrea, Uapaca Kirkiana, Strychnos cocculoides, Vangueria. infausta, Parinari curatellifolia, Z. Mauritania, Adansonia digita, Syzigium cordum and Vitex spp (Akinnifesi et al, 2006). In west and central Africa, focus has been on species such as V. parodoxa, P. biglobosa, Dacryodes edulis, Irvingia gabonensis and Garcinia kola (Leakey et al, 2004; Degrande et al, 2006; Ayuk et al, 1999a; 1999b; 1999c). In Eastern Africa, priority has been given to V. parodoxa, T. indica, Vitex doniana and A. digitata (Matig and Chikamai, 2009, Muok et al, 2001; Okullo et al 2003).

\subsection{Woodlots}

Many countries in Africa face severe shortages of fuelwood, poles for construction and many other forest products due to, in part, increasing human and livestock populations that have led to massive deforestation and land degradation. In Kenya, for instance, extrapolations indicate that the area under plantation forests is expected to decrease from 164,000 ha to 80,000 ha by the year 2020 (KEFRI, 1999). It is further estimated that if the current utilization and demographic factors remain unchanged, then the demand for wood and non-wood forest products is going to outstrip the supply by very big margins. This deficit is likely to manifest itself mainly in fuelwood scarcity, a burden that will be borne by women. To overcome this problem, many development agencies in sub-Saharan Africa have been promoting planting of woodlots, an agroforestry practice which aims at improving fuelwood supply and poles to rural communities, income generation and alleviating environmental degradation.

A woodlot refers to planting of trees in sole stands on farm to provide wood for fuel and construction poles (Otsyina et al, 1999). For the past two decades, woodlots have been promoted in rural areas of Africa and Asia as a means of improving fuel wood supply and poles in rural communities. A number of countries such as South Africa (Ham, 2000), Tanzania (Shanks, 1990) and Ethiopia (Jagger et al, 2005) initially promoted communal woodlots, but due to labour constraints and lack of autonomy many farmers prefer individual woodlots planted on their own parcels of land. In recent years, many NGOs have been encouraging farmers to plant woodlots through agroforestry so that they can be self sufficient in wood product requirements. Modifications of the woodlot technology include planting trees along farm boundaries or intercropping with other tree crops.

In Kenya, planting of woodlots is widespread in high potential areas of western, central and eastern Kenya. Species commonly planted in western Kenya are Eucalyptus spp. and Markhamia lutea. In the coastal region of Kenya, species mainly planted in woodlots is Casuarina equstifolia. In western Uganda species commonly planted are Senna spectabilis, Markhamia lutea, Eucalyptus spp and Melia azederach, among many others (Buyinza and Ntakimanye, 2008). In Malawi, common species are Senna siamea and Eucalyptus spp (Chikoko, 2002). In Tanzania, woodlots are common in Tabora and Shinyanga regions; common species are the Australian acacias such as $A$. crassicarpa, $A$. jurifera, A. leptocarpa and $A$. auriculiformis. Other species 
include Leucaena pallida and Senna siamea (Nyadzi et al, 2003).

Despite the limitations faced by women in Africa, they are increasingly exercising their user rights to land and tree resources by testing and adopting agroforestry. To fully understand how women across Africa are involved in agroforestry, we formulated seven research questions (see Section 3) which are discussed in relation to various agroforestry practices.

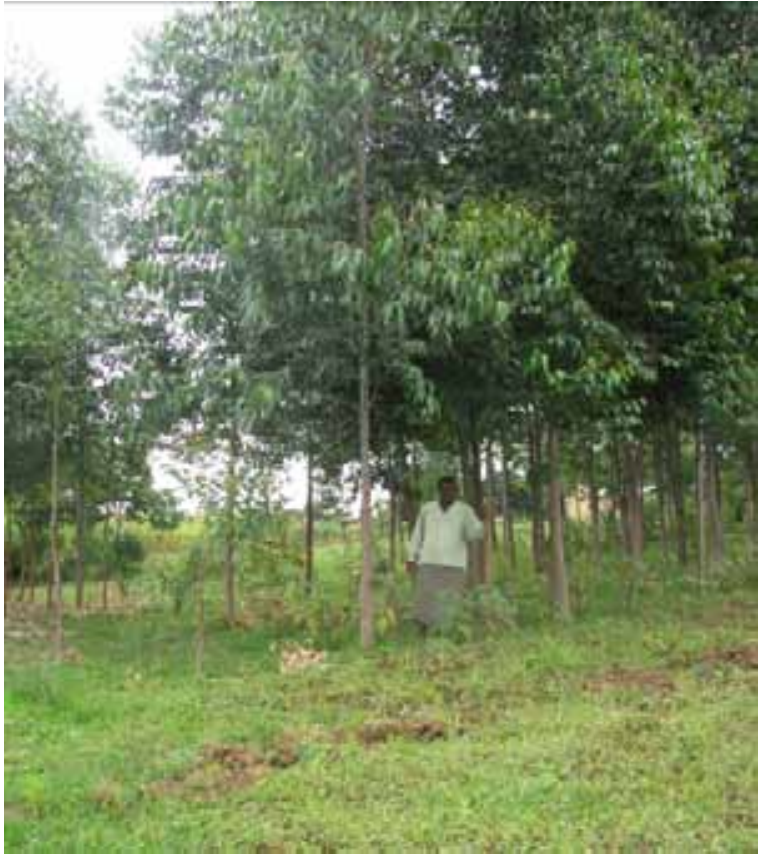

Photo 6: A woodlot of Eucalyptus spp. in Uasin Gishu, Kenya (S. Franzel) 


\subsection{Women's Participation In Agroforestry}

\subsection{What is the proportion of women participating in agroforestry?}

In a study on the achievement and impact of a fodder project in the central highlands of Kenya, Wambugu et al (2001) found that out of 2,600 group members involved in establishing fodder shrub nurseries, $60 \%$ were women (Table 7). Female-headed households accounted for $15 \%$ of all planting households which is roughly the same proportion of female-headed households in central Kenya (Kimenye, 1998). The high participation of women was facilitated by project extension staff, who targeted women's groups or groups with mostly women members.

Whereas the participation of women and femaleheaded households was substantial, female heads of households planted only half as many shrubs as men (Table 8).

The reasons for this result are unclear; it may be because female-headed households wanted fewer seedlings or because they were unable to obtain as many as male-headed households.

A review of 10 studies undertaken in Kenya, Zambia, Uganda and Malawi on factors likely to affect the adoption of improved fallows, biomass transfer and mixed intercropping technologies showed that in eight studies gender did not significantly influence the use of soil fertility technologies for soil fertility management (Table 9).

These findings are consistent with most reviews in the literature on gender differences in agricultural productivity. For example, Quisumbing (1996) review on male-female differences in agricultural productivity found that most studies examining differences in technical efficiency between male and female farm managers found only insignificant differences. That is, female farmers are equally efficient as male farmers if individual characteristics and input levels are controlled. In another review of several studies on gender differences in non land agricultural inputs, Peterman et al (2010) found that most of them did not show any significant difference between men and

Table 7: Types of farmers and groups establishing fodder shrub nurseries in the central highlands of Kenya

\begin{tabular}{|lcclll|}
\hline Gender of farmer & No. & $\%$ & Type of group & No. & $\%$ \\
Female & 1560 & 60 & Mixed groups & 115 & 76 \\
Male & 1040 & 40 & Women's groups & 22 & 15 \\
& & & Men's groups & 13 & 9 \\
Total & $\mathbf{2 6 0 0}$ & $\mathbf{1 0 0}$ & & $\mathbf{1 5 0}$ & $\mathbf{1 0 0}$
\end{tabular}

Source:Wambugu et al (200I)

Table 8: Numbers of fodder shrubs planted by male and female heads of households in Central Kenya in 2004

\begin{tabular}{llll} 
& Male-headed households & Female-headed households & Significance level \\
No. cases & 109 & 19 & \\
No. trees planted & 274 & 135 & .000 \\
No. trees survived & 160 & 43 & .002 \\
\hline
\end{tabular}

Source: Steven Franzel, pers. comm. 
Table 9: Analysis of studies on factors affecting adoption of soil fertility options with gender as a variable

\begin{tabular}{|c|c|c|c|c|c|}
\hline Author & Country & Technology & $\begin{array}{l}\text { Gender } \\
\text { Significant }\end{array}$ & $\begin{array}{l}\text { Gender } \\
\text { Insignificant }\end{array}$ & Comment \\
\hline Phiri et al (2004) & Zambia & Improved fallow & & $\checkmark$ & $\begin{array}{l}\text { Men and women equally } \\
\text { planted improved fallows, but } \\
\text { women had smaller plots }\end{array}$ \\
\hline Keil et al (2005) & Zambia & Improved fallow & & $\checkmark$ & Same as above \\
\hline Kiptot et al (2007) & Kenya & Improved fallow & & $\checkmark$ & $\begin{array}{l}\text { Both men and women equally } \\
\text { practice the use of IF }\end{array}$ \\
\hline Place et al (2004) & Kenya & Improved fallow & & $\checkmark$ & $\begin{array}{l}\text { Women practice the use } \\
\text { of IF and biomass transfer } \\
\text { technologies more than men }\end{array}$ \\
\hline $\begin{array}{l}\text { Thangata and Alavalapati } \\
(2003)\end{array}$ & Malawi & Mixed intercropping & & $\checkmark$ & $\begin{array}{l}\text { Both men and women equally } \\
\text { practice mixed intercropping } \\
\text { of Gliricidia sepium and maize }\end{array}$ \\
\hline $\begin{array}{l}\text { Buyinza and Wambede } \\
\text { (2008) }\end{array}$ & Uganda & Mixed intercropping & $\checkmark$ & & $\begin{array}{l}\text { Adoption was higher for men } \\
\text { than women farmers }\end{array}$ \\
\hline Kiptot (2008) & Kenya & & & $\checkmark$ & $\begin{array}{l}\text { Men and women equally } \\
\text { practiced the use of biomass } \\
\text { transfer }\end{array}$ \\
\hline $\begin{array}{l}\text { Obonyo and Franzel } \\
(2004)\end{array}$ & Kenya & Biomass transfer & $\checkmark$ & & $\begin{array}{l}\text { Adoption was higher in male- } \\
\text { headed households than in } \\
\text { female-headed households }\end{array}$ \\
\hline Franzel (1999) & $\begin{array}{l}\text { Western } \\
\text { Kenya and } \\
\text { Southern } \\
\text { Africa }\end{array}$ & Improved fallows & & $\checkmark$ & $\begin{array}{l}\text { Both men and women equally } \\
\text { practice the use of IF }\end{array}$ \\
\hline Ajayi et al (200I) & Zambia & Improved fallow & & $\checkmark$ & $\begin{array}{l}\text { Both men and women equally } \\
\text { practice the use of IF }\end{array}$ \\
\hline
\end{tabular}

women farmers on the adoption of inputs such as inorganic fertilizer and improved seed.

In western Kenya, Place et al (2004) reported that women used improved fallows and biomass transfer technologies more than men, who more often used fertilizer (Figure 3).

In Zambia, Phiri et al (2004) showed that there were no significant differences between proportions of men and women household heads practising the use of improved fallows nor were there any significant differences between single women and female heads of households who were married even though single women are often disadvantaged when compared to female heads whose husbands work away from home (Table 10). Surprisingly, Peterson (1999) found a higher proportion of single females planting improved fallows than married females; the latter probably needed permission from their husbands who may have prevented them from testing improved fallows.

Phiri et al (2004) found that in four Zambian villages, $32 \%$ of males and $23 \%$ of females planted improved fallows. There was considerable variation within villages with one having more females than males planting improved fallows. According to Phiri et al (2004) this variation could be attributed to the presence of active women's groups. These findings suggest that the use of improved fallows for replenishing soil fertility is gender neutral; women farmers are as actively involved as their male counterparts. However, women in Zambia had smaller plots than men, $332 \mathrm{~m}^{2}$ as compared to 679 $\mathrm{m}^{2}$ for men. Since the same percentage of males and females stated that they had obtained enough planting material, it appears that females wanted smaller plots than males (Franzel et al 2002). This finding may be attributed to the heavy workload that women bear: 
multiple roles and tasks; land and labour constraints or risk aversion (Keil et al, 2005; Franzel et al, 2002).

In contrast to fodder production and soil fertility management, women's participation in indigenous fruit and vegetable enterprises is much greater because indigenous fruits in sub-Saharan Africa are considered a domain for women and children (Campbell, 1987). A probable explanation for this perception is that markets for these products are not well developed, and therefore they are considered subsistence by men. But there are also concerns in the literature that as these products become more of a cash crop; the benefits may shift from women to men (Poulton and Poole, 2001).

Since fruits are considered a women's domain, men in Mali maintain shea trees in the cropland because they are a key source of income for their wives. In the shea

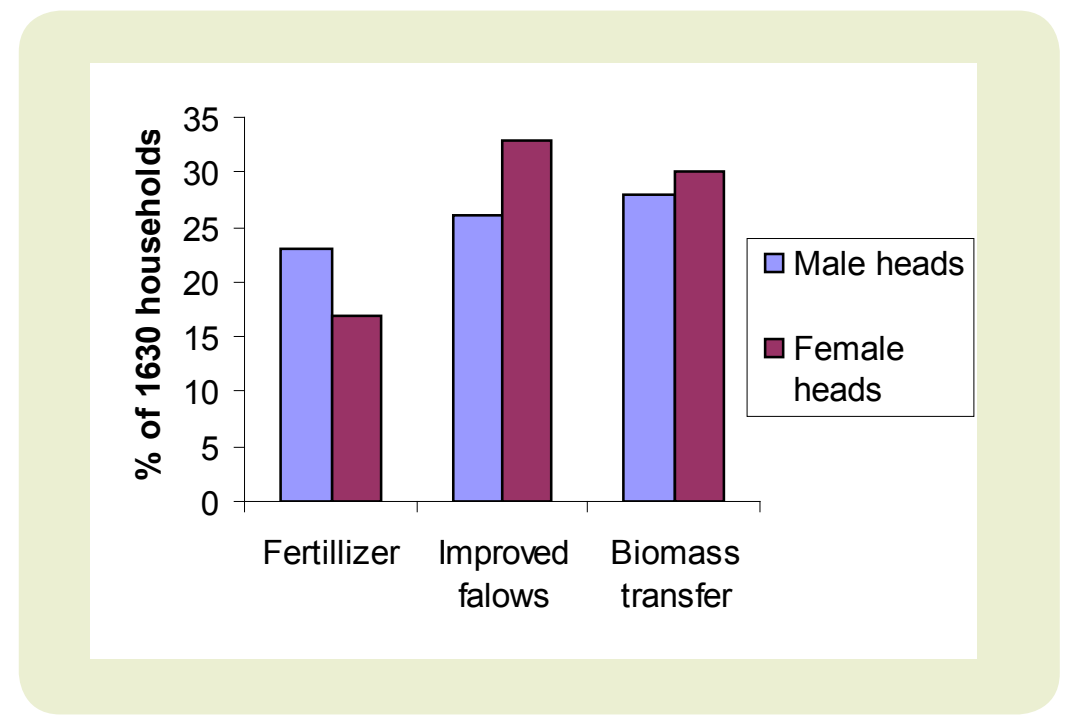

Source: Place et al (2004)

Figure 3: Use of soil fertility management options by gender of household head, western Kenya

Table 10: Association between gender of household head and the planting of improved fallows in eastern Zambia (\% in brackets)

\begin{tabular}{llll|lll|} 
& \multicolumn{2}{c|}{ Males } & \multicolumn{3}{c}{ Females } \\
Village & Planting & Not planting & Total & Planting & Not planting & Total \\
Mshaba & $16(48)$ & $17(52)$ & $33(100)$ & $8(61)$ & $5(39)$ & $13(100)$ \\
Kasauka & $15(65)$ & $8(35)$ & $23(100)$ & $3(30)$ & $7(70)$ & $10(100)$ \\
Chivungwe & $8(22)$ & $28(78)$ & $36(100)$ & $4(18)$ & $18(82)$ & $22(100)$ \\
Fisi & $6(13)$ & $41(87)$ & $47(100)$ & $3(9)$ & $31(91)$ & $34(100)$ \\
Total & $45(32)$ & $94(68)$ & $139(100)$ & $18(23)$ & $61(77)$ & $79(100)$
\end{tabular}


growing region of Benin, Schreckenbreg (2004) found out that $90 \%$ of women were involved in collecting nuts/fruits of the shea tree. Other tree products that are frequently collected by women and children in west and central Africa are: Parkia biglobosa, Dacryodes edulis, Irvingia gabonensis and Ricinodendron heudelotii.

In southern Africa, common species collected by women include, Sclerocarya birrea, Uapaca Kirkiana, Vangueria infausta, Azanza garkeana, Ziziphus Mauritania and Strychnos cocculoides. As shown in Figure 4, the proportion of households collecting such fruits is very high. In eastern Africa are; $V$. parodoxa, Tamarindus indica, Vitex doniana and Adansonia digitata. Other studies that have reported similar findings of women and children being the main collectors are for instance Kalaba et al (2009) in Zambia; Campbell (1987) in Zimbabwe; and Ruiz-Perez et al (1997) in selected areas of eastern and southern Africa. Women normally combine fruit collection with other household chores such as collecting fuelwood and fetching water.

In Benin, household heads normally reserve nuts of the shea tree for their female relatives. When the fruits are in season, women start collecting shea fruits from common parklands where competition from other women is stiffer. Collection is normally done on their way to and from the agricultural fields. In a day, women collect head loads of up to $47 \mathrm{~kg}$. When the shea fruits from the common parklands have been exhausted, the women turn to their husbands' field to collect the shea fruits.

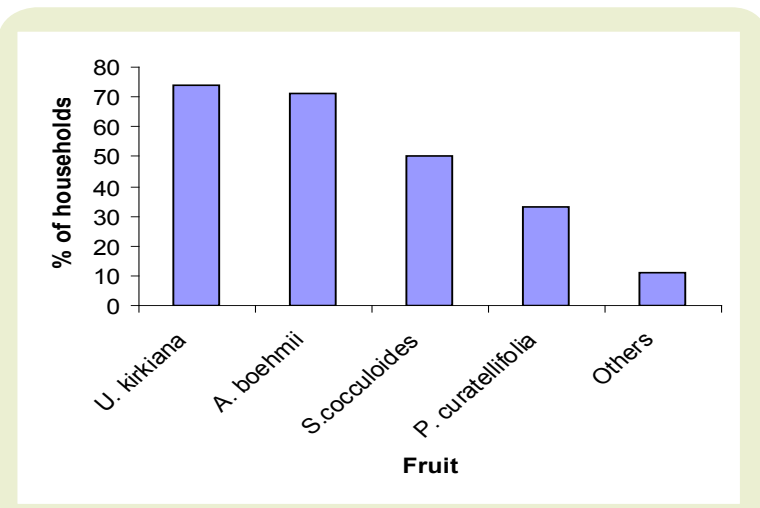

Source: Kalaba et al (2009)

Figure 4: Proportion of households collecting different indigenous fruits in Mwekera area, Zambia
A study of gender and commercialization of Gnetum africanum in Cameroon by Kanmegne et al (2007) found that women and children are also the main collectors of the leaves which are used as a vegetable. They accounted for $80 \%$ of the collectors while men accounted for less than $5 \%$ of collectors (Figure 5).

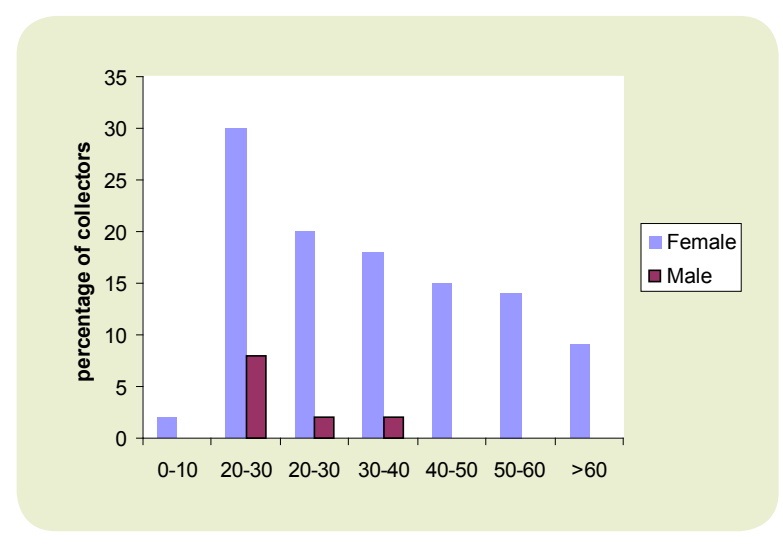

Source: Kanmegne et al (2007)

Figure 5: Age (years) categories of G. africanum collectors in central Cameroon

Men considered $G$. africanum activities and especially collection to be a time consuming and not rewarding activity compared to cocoa, a traditional source of income for men. And the fact that $G$. africanum income comes in at a time when cocoa is harvested renders it unattractive to men.

Apart from collecting, women are also involved in processing to add value to fruit tree products. Shea kernels are processed into local butter. This process is laborious and not a particularly profitable business. As a result, very few women are involved. In some parts of Benin such as Bassila area, women who make butter, also make traditional soap from left over and rancid butter. This soap is sold locally, and it is said to have skin healing properties (Schreckenbreg, 2004). In southern Africa, products that women process from indigenous fruits or nuts include alcoholic and non-alcoholic beverages, confectionaries, additives for other foods, dried whole fruits, oil and butter (Table 11).

In addition to soil fertility management, fodder production, indigenous fruits and vegetable production and processing, women are also involved in establishment and management of woodlots. In a study by Chikoko (2002), on the analysis of household-owned woodlots between female-headed 
and male-headed households in Malawi, she noted that most women $(96 \%)$ in female-headed households individually owned the woodlots. Most (61\%) women in male-headed households stated that the woodlot is co-owned with the husband, $30 \%$ said the husband owns the woodlot, and $8 \%$ said they owned the woodlot independently. When the same question was posed to men in male-headed households, $73 \%$ of them said they owned the woodlot individually while only $27 \%$ of the men said they co-owned with their wives. On the number of trees, female-headed households tended to have half as many trees as maleheaded households, reflecting the fact that their farms were half as large (Table 12). This confirms data in the literature that women who have adopted agroforestry technologies often have smaller areas and fewer trees (Keil et al, 2005; Schreckenberg et al, 2002; Wanyoike, 2001)
In summary, women's participation is particularly high in enterprises that are considered to be their domain, such as indigenous fruit and vegetable products and processing. Projects introducing new agroforestry practices have been successful in gaining the participation of high proportions of women, in part because the enterprises appear attractive to women and because the projects target women. For example, some specifically work with women's self-help groups. However, the degree of involvement of women in using the practices, relative to men, is often low as measured by the number of trees they plant or the area they allocate. The lower involvement reflects women's lack of resources, particularly land and labour, and perhaps also their greater aversion to risk.

Table I I: The range of products being processed by rural women in Southern Africa

$\begin{array}{ll}\text { Country } & \text { Product } \\ \text { Malawi, Zambia } & \text { Baobab juice and wine (A.digitata), Masuku juice, jam (U.kirkiana), Marula wine (S. birrea) } \\ \text { Zimbabwe } & \begin{array}{l}\text { Parinari oil (P. curatellifolia), S.cocculoides jelly, Masuku jam (U.kirkiana), Marula oil and } \\ \text { jelly (S. birrea), Masau leather (Z. Mauritania), Baobab oil and cereal bar (A.digitata) }\end{array} \\ \text { Tanzania } & \begin{array}{l}\text { Baobab juice (A. digitata), Syzygium juice (S. guineense), Strychnos juice (S. cocculoides), } \\ \text { Vitex jam (V. mombassae). }\end{array}\end{array}$

Source: Akinnifesi et al (2006)

Table I 2: Land size, number of trees and woodlot size by household type in Malawi

\begin{tabular}{|llll|}
\hline Household type & Land size (acres) & Woodlot size (acres) & Number of trees \\
\hline Female-headed households & $2.7(51,1.9)$ & $0.84(42,0.7)$ & $840(51,1719)$ \\
Male-headed households & $5.5(60,5.3)$ & $1.56(55,1.6)$ & $1666(63,2278)$ \\
\hline
\end{tabular}

Note: Figures in parenthesis are sample size and standard deviation

Source: Chikoko (2002) 


\subsection{Are women able to manage agroforestry practices?}

Although men and women are both involved in management of trees planted on farms, the literature confirms the fact that women do most of the work, especially at the initial stages of tree establishment. In a study conducted by Epaphra (2001) in Tanzania and Gerhardt and Nemarundwe (2006) in Zimbabwe, it was noted that over $60 \%$ of women in Tanzania (Table 13) are responsible for managing tree species planted on farms while over $80 \%$ in Zimbabwe are responsible for watering young seedlings (Table 14).

This trend is confirmed by another study that was done by the National Agroforestry Research Project in Embu, Kenya to determine early stages of adoption of calliandra fodder in the central highlands of Kenya.
It was found that although $91 \%$ of households using calliandra fodder were male-headed, in $89 \%$ of these households, females were responsible for managing calliandra (Franzel et al, 2002). A similar scenario was observed in Uganda by Nyeko et al (2004) where the proportion of households in which women managed calliandra was $83 \%$ in Lake Victoria Crescent, $97 \%$ in the Southern Drylands and $84 \%$ in the Southern Highlands. Husbands managed their farms jointly with their wives. Another study by Wanyoike (2001) on adoption of calliandra by gender, it was noted that more male-headed households (17\%) than femaleheaded households (11\%) had adopted calliandra (Table 15). Farms managed jointly by men and women had many more trees than those managed solely by men or women, perhaps because the jointly managed farms had access to pooled labour provided by both spouses.

Table I 3: Responsibility for managing planted trees in Marangu and Mamba districts, Tanzania

$\begin{array}{ll}\text { Persons responsible } & \text { \% of households }(\mathrm{n}=\mid \mathrm{I} 0) \\ \text { Female adults } & 61.8 \\ \text { Male adults } & 10.0 \\ \text { Female and male adults } & 10.9 \\ \text { Whole family } & 2.7 \\ \text { Female adults \& hired labour } & 3.6 \\ \text { Female adults \& male children } & 10.9 \\ \text { Total } & 100\end{array}$

Source: Epaphra (200I)

Table I4: Management of planted indigenous trees species by gender in Chivi district Zimbabwe

\begin{tabular}{|lll|}
\hline Inputs & Women (\%) & Men (\%) \\
& $\mathrm{n}=31$ & $\mathrm{n}=14$ \\
Fertilizers (manure, leaves) & 68 & 50 \\
Watering & 81 & 50 \\
Weeding & 19 & 21 \\
Protection against grazing & 39 & 7 \\
\hline
\end{tabular}

NB: Percentages summed across do not necessarily add to 100 because in some cases men and women share responsibility Source: Gerhardt and Nemarundwe (2006). 


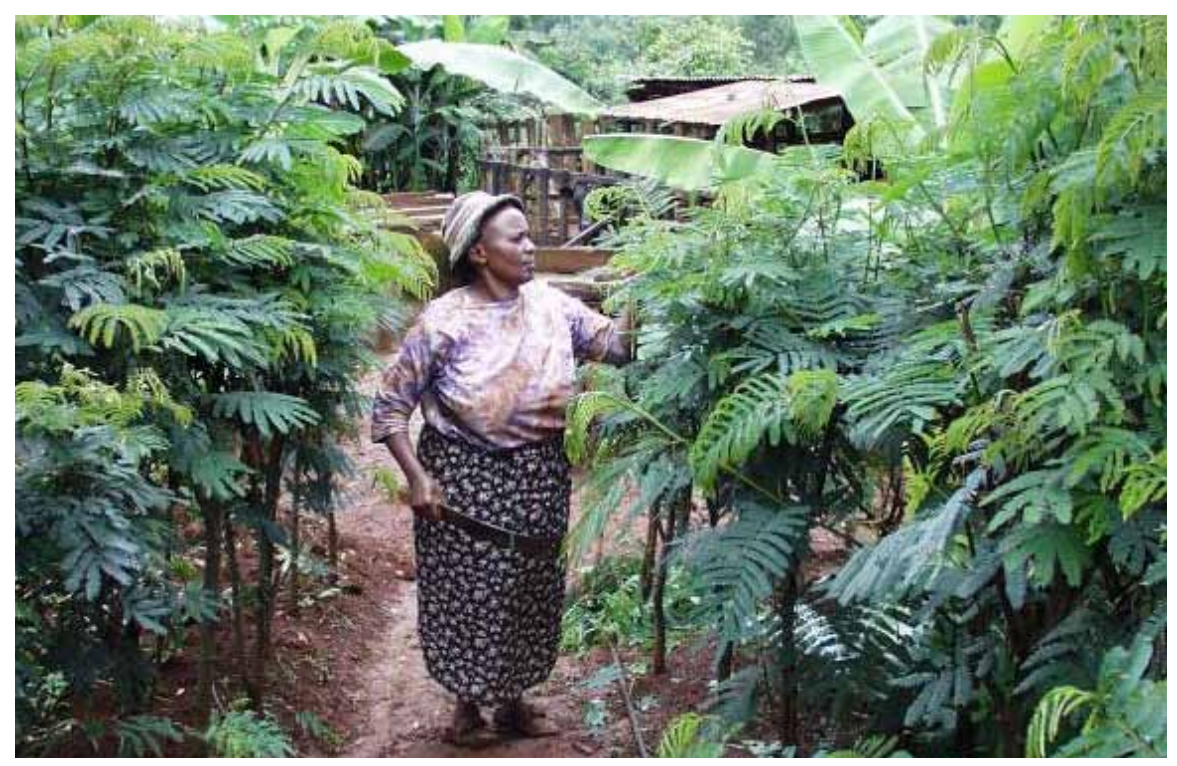

Photo 7: A female farmer in Embu, Kenya cutting calliandra fodder (S. Franzel)

Comparing tree survival rates between men and women is one indicator of the degree to which the genders are differentially able to manage tree technologies. The results of such analyses are mixed. In Kenya, male-headed households had somewhat higher survival rates for fodder shrubs than women ( $45 \%$ as compared to $31 \%$ ) but the differences were highly variable and not significant (Steven Franzel, pers. comm.). Possible reasons for low survival rates could have been because less labour was available for maintaining the seedlings or a lack of knowledge about how to maintain them. In eastern Zambia, survey data on Sesbania sesban supports the hypothesis that women were able to manage improved fallows as well as men. In farmer-designed, farmer-managed trials planted in 1995/96, half of the participants were women and they had somewhat higher survival rates for sesbania than men. For example, $47 \%$ of women but only $29 \%$ of men had survival rates for sesbania of over $75 \%$, six months after planting. For Tephrosia vogelii, men had somewhat higher survival rates. Men and women reported similar problems with similar frequency and did not differ in the number of times they weeded their trees (Franzel et al, 2002).

In summary, women are frequently responsible for managing trees and as with other agricultural enterprises women do most of the work. Data are mixed on whether women are able to manage agroforestry practices as well as men. In cases where they do not perform well, the reasons are likely varied and include lack of knowledge, lack of access to extension service, and scarcity of resources, particularly labour.

Table I5: Calliandra fodder adoption in Embu district, Kenya

\begin{tabular}{|llll|} 
& N & \% of farms with Calliandra & Average No. of calliandra trees \\
All farm households & 300 & 16 & 89 \\
Male-headed households & 272 & 17 & 80 \\
Male managed farms & 59 & 18 & 35 \\
Joint managed farms & 179 & 17 & 120 \\
Female managed farms (de facto) & 34 & 16 & 20 \\
Female-headed households (de jure) & 28 & 11 & 89 \\
\hline
\end{tabular}

Source:Wanyoike (200I) 


\subsection{What are women's preferences/rating of various tree species and motivation for planting trees?}

Men and women often have different objectives for planting trees. Men are typically interested in trees for commercial purposes while women are more inclined to plant trees for subsistence use such as firewood, soil fertility improvement, fodder and fruits. This difference is confirmed by a study undertaken in Malawi by Chikoko (2002) on important tree attributes in tree planting by gender (Table 16). Women in female-headed households considered trees that grow fast as their first choice (34.8\%), followed by trees with good burning qualities $(22 \%)$, and trees that produce a lot of charcoal when cooking (15.2\%). In contrast, men ranked trees that grow straight $(52.5 \%)$ as their first choice; an indication that timber is their number one priority. Straightness was followed by trees that grow fast $(20 \%)$. Another study in western Kenya on the use of tree products by gender, found that both men and women equally use tree products, with more men than women using timber, but when it comes to fuelwood it is vice-versa (KWAP, 1996). In Burundi, women had similar preferences to men but selected Markhamia lutea for planting because they use the leaves to prepare medicine for treating their children's diarrhea. Men rejected the species because it was not good for timber (Franzel et al, 1995).

Many studies report that planting of trees is attractive to men because of the commercial benefits they get from selling poles, timber and fuelwood while women are interested in fuelwood for domestic use (Rocheleau and Edmunds, 1997; Rocheleau, 1991). Fortunately, it is possible to manage some tree enterprises for multiple products, in a way that both men and women can benefit. For example, men and women in central Kenya share responsibility for managing Grevillea robusta plantings with the men benefiting from pole and timber production and the women using branches for fuel. Men earned cash from pole and timber sales and three-quarters of women interviewed said that the presence of grevillea trees on their farm greatly reduced the time they spent off the farm collecting firewood (Tyndall and Franzel, 1998). A study conducted in Malawi found that wood for use at home is important for both men and women (Table 17). What is not clear is whether the fuelwood from the Malawi study is for curing tobacco, a man's crop or for household cooking or both.

Both female and male-headed households in Malawi planted trees for household use as the main reason with very few farmers in both types of households citing sales as a reason. In western Kenya, though, commercial tree growing on farms is a multi-billion shilling business that was occasioned by the ban on tree harvesting from government forests. Statistics from the Kenya Forest Service indicate that 690,000-800,000 ha which account for $20 \%$ of the land holdings in western Kenya are under Eucalyptus spp. (The Daily Nation, $16^{\text {th }}$ May 2008). No data is available to show the proportion for commercial purposes and household use.

In the Tabora region of Tanzania and in some parts of Malawi, farmers are attracted to woodlots because of scarcity of fuelwood for cooking and curing tobacco. Tobacco farming requires substantial amounts of wood

Table 16: Important tree attributes in tree planting by gender of household head in Malawi

\begin{tabular}{|llllll|}
\hline Household Type & \multicolumn{4}{c}{ Tree attributes (\% of respondents) } \\
& Grows fast & Grows straight & Burns well & $\begin{array}{l}\text { Produces } \\
\text { charcoal }\end{array}$ & Other \\
\hline $\begin{array}{l}\text { Female-headed } \\
\text { households }(\mathrm{n}=46)\end{array}$ & 34.8 & 19.6 & 21.7 & 15.2 & 8.7 \\
$\begin{array}{l}\text { Male-headed households } \\
(\mathrm{n}=40)\end{array}$ & 20.0 & 52.5 & 0.00 & 17.5 & 10.0 \\
\hline
\end{tabular}

Note:The rankings were from first to third most important attribute. The table shows frequencies of tree attributes that received first ranking. 
for a variety of purposes, such as curing and poles for barn construction. Tobacco farmers in Tanzania used to get all of their firewood from the miombo woodlands, but this is no longer the case as deforestation takes its toll. Farmers are therefore opting for alternative sources of fuelwood such as having an on-farm supply, hence the interest in woodlots.

Whereas women often have different planting objectives and evaluation criteria than men, we found remarkably little variation in the way they score different species on different criteria. In a study in Zambia by Kuntashula and Mafongoya (2005), men and women rated 11 species across five criteria, that is, making 55 different ratings (Table 18). But in only two of the ratings was there a significant difference between men and women. Similarly in Kenya, men and women rated six different benefits from improved fallow practices and men and women differed in their ratings on only one of the benefits, the impact on soils (Pisanelli et al, 2008). Women scored the benefits to soil higher than men did, perhaps because they spend more time in the field and were more aware of the benefits to soils.

In summary, women have a stronger interest in trees for domestic use (e.g., firewood and medicines) while men prefer trees for earning cash (e.g. timber) There do not appear to be many differences in the way they judge the performance of trees on particular criteria.

Table 17: Primary reasons for establishing woodlots in Malawi by gender of household head

\begin{tabular}{|c|c|c|c|}
\hline \multirow[t]{2}{*}{ Household type } & \multicolumn{3}{|c|}{ Reason for woodlot establishment (\% of respondents) } \\
\hline & Household fuelwood & Household poles & Products for sale \\
\hline $\begin{array}{l}\text { Female-headed households } \\
(n=44)\end{array}$ & 73.8 & 19.0 & 7.1 \\
\hline $\begin{array}{l}\text { Male-headed households } \\
(n=43)\end{array}$ & 53.5 & 37.2 & 9.3 \\
\hline
\end{tabular}

Source: Chikoko (2002)

Table I8: Rating trees for major benefits differentiated by gender a in eastern Zambia

\begin{tabular}{|c|c|c|c|c|c|c|c|c|c|c|}
\hline \multirow[t]{2}{*}{ Species } & \multicolumn{2}{|c|}{ Soil fertility } & \multicolumn{2}{|c|}{ Fuelwood } & \multicolumn{2}{|c|}{ Poles } & \multicolumn{2}{|c|}{$\begin{array}{l}\text { Light construction } \\
\text { materials }\end{array}$} & \multicolumn{2}{|c|}{ Fodder } \\
\hline & Men & Women & Men & Women & Men & Women & Men & Women & Men & Women \\
\hline A. angustissima & 3.1 & 3.4 & 2.3 & 2.6 & 1.5 & 1.9 & 2.7 & 2.7 & 3.1 & 3.3 \\
\hline L. pallida & 2.6 & 2.6 & 2.8 & 3.1 & 2.7 & 2.6 & 3.4 & 3.3 & 2.4 & 2.8 \\
\hline L. esculenta (Machakos) & $2.3^{b}$ & $2.7^{b}$ & 2.1 & 2.2 & 1.4 & 1.5 & 1.8 & 2.0 & 2.4 & 2.7 \\
\hline L.diversifolia (35/88) & 2.3 & 2.2 & 2.3 & 2.4 & 2.0 & 2.0 & 3.0 & 2.8 & 2.6 & 2.9 \\
\hline L. diversifolia (53/88) & 2.3 & 2.5 & 2.5 & 2.6 & 2.0 & 2.1 & 3.0 & 2.8 & 2.6 & 2.9 \\
\hline C. calothyrsus (ex Embu) & 2.8 & 3.0 & 2.8 & 2.8 & 1.8 & 1.9 & 2.9 & 2.8 & 2.9 & 3.0 \\
\hline S. siamea & 1.7 & 1.6 & 3.0 & 3.0 & 2.2 & 2.6 & 1.9 & 2.1 & 1.4 & 1.6 \\
\hline L. esculanta $(52 / 87)$ & 2.8 & 2.7 & 3.0 & 3.0 & 2.4 & 2.6 & 3.5 & 3.3 & 2.6 & 2.9 \\
\hline S. spectabilis & 2.0 & 2.0 & 2.2 & 2.3 & 1.3 & 1.6 & 1.5 & 1.6 & 1.4 & 1.4 \\
\hline L. collinsii $(45 / 85)$ & 3.2 & 3.2 & 3.0 & 3.1 & 2.5 & 2.7 & 3.3 & 3.4 & $2.8^{b}$ & $3.2^{\mathrm{b}}$ \\
\hline G. sepium & 3.8 & 4.0 & 2.7 & 2.7 & 1.9 & 1.9 & 2.9 & 2.8 & 1.7 & 1.7 \\
\hline
\end{tabular}

a A total of 55 males and 57 females were involved in the study

b Mean score difference significant at $5 \%$ level

Source: Kuntashula and Mafongoya (2005) 


\subsection{How do women benefit from agroforestry?}

Women's rights to tree products are usually limited to products that are considered to have little or no commercial value. These products are mainly indigenous fruits and vegetables, fodder, and mulch. KWAP (1996) reported that while only men had the right to harvest all trees, over $50 \%$ of women had the right to use Sesbania sesban. This is because sesbania only provides green manure and fuelwood, products that are not considered to be important to men (Table 19). More men than women use timber products (Table 20), a confirmation that timber is a man's domain. This also explains why womens' rights to harvest timber trees such as Markhamia lutea and Casuarina equstifolia are sharply curtailed in western Kenya (Table 19).

\begin{tabular}{|c|c|}
\hline Tree species & $\%$ of women \\
\hline Persea Americana & 53 \\
\hline Mangifera indica & 49 \\
\hline Citrus sinensis & 48 \\
\hline Callindra calothyrsus & 48 \\
\hline Sesbania sesban & 52 \\
\hline Acacia Mearnsii & 45 \\
\hline Leuceana lecocephala & 49 \\
\hline Grevillea robusta & 49 \\
\hline Markhamia lutea & 15 \\
\hline Casuarina equstifolia & 13 \\
\hline
\end{tabular}

Source: KWAP (1996)
Although calliandra as a fodder has been shown to be profitable for farmers, no studies in the literature have been found that show the direct benefit in economic terms that accrue to women farmers who grow calliandra. An economic study undertaken in several sites in Kenya and Uganda shows that beginning second year after planting 500 calliandra shrubs, a farmer's net income increases by about US\$ 101 to US\$ 122 a year by substituting dairy meal with calliandra. On the other hand, if a farmer uses calliandra fodder shrubs as a supplement for dairy meal, their income increases by about US\$ 62 to US\$ 115 a year. This is roughly $5-10 \%$ of the total income from the farm. The study did not, however, look at how much women receive from the sale of milk or what percentage of women have access to the income from the sale of milk. Farmers greatly appreciate the cash they save by feeding calliandra as high-protein supplement to their livestock instead of having to purchase dairy meal which accounts for $46 \%$ of the cost of the cattle enterprise in the central Kenya farming system (Muriithi and Franzel, 2001). The funds generated are used to pay school fees and for general household improvements such as building a good house and feeding stalls. In addition to boosting milk production, other benefits from fodder shrubs include improved animal health, fuelwood which goes directly to women, improved nutrition of the family, seedling sales, high quality manure, bee forage and stakes for vegetable production in addition to environmental benefits such as control of soil erosion (Table 21). Access to home grown fodder and availability of firewood from the prunings frees up women's labour for other productive enterprises. It is thus expected that a technology that would reduce costs and offer multiple benefits, would also improve the welfare of women who are responsible for feeding

Table 20: Use of tree products by gender in Western Kenya

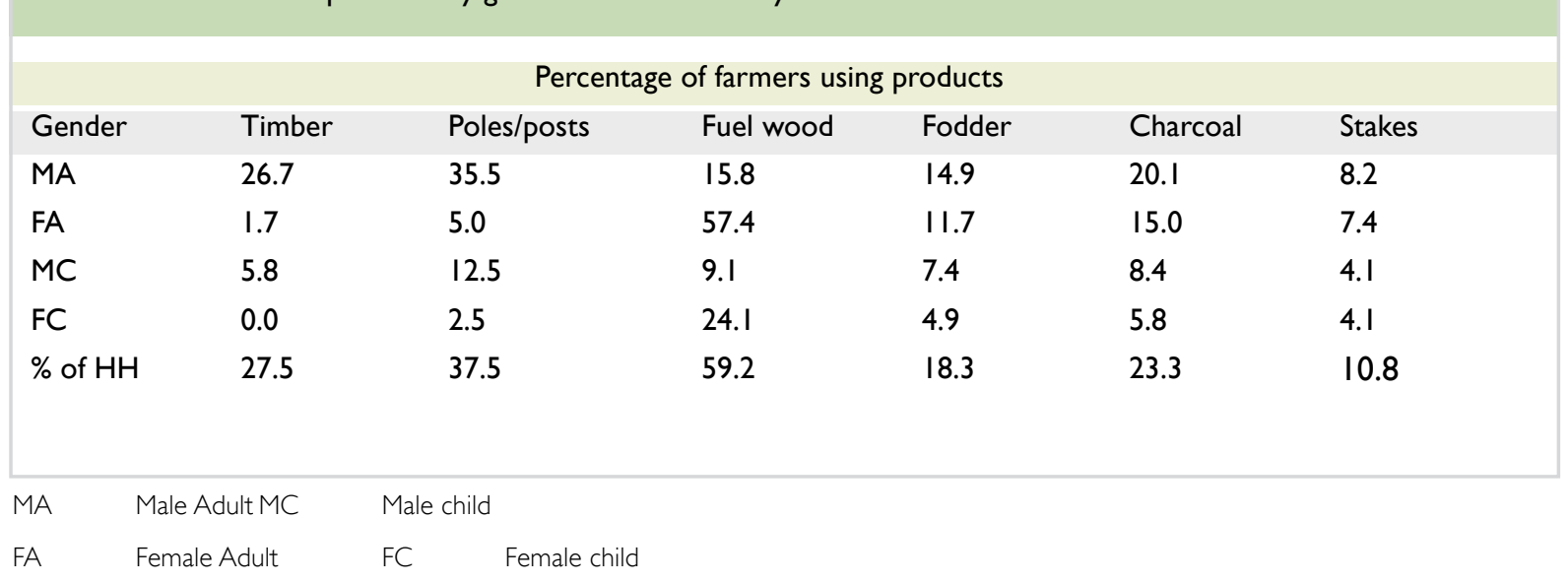


their family's livestock. A detailed study is needed to quantify the actual benefits in monetary terms that women get by using calliandra on farms.

Low cost agroforestry practices for replenishing soil fertility are attractive to women farmers because they involve low inputs but high returns. Apart from the obvious benefit of improving soil fertility, reflected in the high maize yields, they also provide fuelwood and reduce the incidence of weeds such as Striga hermontheca. Although a review of literature does not give the direct benefits that accrue to women farmers in financial terms, the results of focus group interviews with Zambian women suggest that whatever benefits that accrue from the use of improved fallows do benefit women (Paterson, 1999). An economic analysis undertaken by Franzel et
Various studies in Kenya, Uganda and Zambia have shown that improved fallows do indeed generate considerable amounts of fuelwood with the amount varying depending on the species. For instance, 5-42 $\mathrm{t} /$ ha was generated within a duration of $1-3$ years in western Kenya (Swinkels et al, 1997); 24-27 t/ha after two years in south-western Uganda (Siriri and Rausen, 2003); 10 t/ha after two years in eastern Zambia (Sanchez, 1995) and 13.7-21.7 t/ha after 2.7 years in coastal Kenya (Jama and Getahum, 1991).

In another study undertaken by Jama et al (2008) to determine fuelwood production potential from short rotation improved fallows in western Kenya, the results were remarkable. If a farmer planted 0.01 to 0.08 ha (typical size of land planted to improved fallows in

Table 2 I: Benefits of fodder shrubs according to farmers in Embu, Kenya and Kabale Uganda

\begin{tabular}{|lll|}
\hline Type of benefit & $\begin{array}{l}\text { Embu area, Kenya } \\
(\mathrm{N}=56)\end{array}$ & $\begin{array}{l}\text { Kabale area Uganda } \\
(\mathrm{N}=93)\end{array}$ \\
\hline Firewood & $50 \quad(\%$ of farmers $)$ & 72 \\
Soil fertility improvement & 48 & 72 \\
Improvement in animal health & 38 & 5 \\
Soil erosion control & 18 & 20 \\
Improved creaminess of milk & 18 & 6 \\
Fencing & 18 & 76 \\
Revenue from sale of seedlings & 13 & 9 \\
Stakes & 9 & 70 \\
\hline
\end{tabular}

Source: Franzel and Wambugu (2007)

al (2002) shows that agroforestry-based soil fertility management options are much more profitable than current farmers' practices despite forfeiting two seasons of cropping. This is reflected in labour saved, fuelwood production in year 2 , increases in maize yield in years $3-5$, and reduced land preparation and reduced weeding costs in the first post fallow maize crop. These benefits are further confirmed by results from trials conducted in Chipata, Zambia over the last 15 years which show that maize yields after two years of sesbania fallow averaged 5.6 tonnes/ha compared to 2.0 tonnes/ha in unfertilized continuous cropping. Furthermore, 2-year fallows of sesbania produced 15 tonnes of fuelwood per hectare (Franzel et al, 2002; Place et al, 2002).

Apart from increases in crop yields, provision of fuelwood from improved fallows is another direct benefit to women farmers as it reduces their burden of having to travel long distances in search of it. the region), fuelwood harvested would last a typical household between 11.8 to 124.8 days depending on the species and fallow duration (Table 22). This would increase to 268.7 and 1173.7 days if farmers increased the area planted to 0.25 ha (Table 23).

Mugo (1999) estimates that women who collect fuelwood for cooking away from the farm spend on average 130 hours per year, as compared to only 36 hours spent by those who harvest firewood from their own farms. The implication is that the time saved by having an on-farm wood supply can be diverted to other productive chores such as weeding, planting food crops, processing, food preparation and income generating activities. Women farmers who are practising improved fallows are therefore benefiting tremendously from the fuelwood collected which is considered a secondary product. Fuelwood in western 
Kenya, one of the most densely populated areas in Africa, is so scarce that the majority of households use crop residues and cow dung for cooking, resources which would normally have been ploughed back to the farm to increase crop productivity (Mugo, 1999). In a study of the contribution of the shea tree $(V$. paradoxa) to local livelihoods in Benin, Schreckenbreg (2004) found that the tree provides some income to women in Benin. The income from shea, including sale of kernels, sale of butter and own consumption makes up $2.8 \%$ of the total household income. The income may seem small, but it is significant to women in Benin because they are able to control it, is a source of lumpsum income, obtained with no investment other than labour. The income is normally used to cover daily expenditure on sauce ingredients, soap, kerosene and grain milling. A study by Boffa et al, (1996) that interviewed 51 male and 14 female heads of households shows that income from marketing of shea nuts in Burkina Faso was the exclusive right of women in $66 \%$ of the sample, while $27 \%$ shared the control with their family members with a paltry

\begin{tabular}{|c|c|c|c|c|}
\hline \multirow[t]{3}{*}{ Species } & \multirow{3}{*}{$\begin{array}{l}6 \\
\text { t/ha }\end{array}$} & \multicolumn{2}{|c|}{ Fallow duration (months) } & \multirow[t]{3}{*}{ Average } \\
\hline & & 12 & 18 & \\
\hline & & & & \\
\hline C. grahamiana & $5.8(3.5 ; 8 ; 31.5)$ & $4.9(2.3 ; 11 ; 27.5)$ & $13.4(0.7 ; 4 ; 124.8)$ & 8.0 \\
\hline C.paulina & $6.2(1.2 ; 4 ; 46.7)$ & $10.8(2.2 ; 5 ; 13.7)$ & | $4.8(7.8 ; 4 ; 17.2)$ & 10.6 \\
\hline T.vogelii & $5.6(3.8 ; 5 ; 11.8)$ & $6.0(3.0 ; 8 ; 35.4)$ & $10.2(7.6 ; 6 ; 54.4)$ & 7.3 \\
\hline T.candida & $8.9(1.8 ; 6 ; 21.9)$ & $8.4(3.4 ; 5 ; 31.1)$ & $20.2(9.4 ; 5 ; 47.0)$ & 12.5 \\
\hline
\end{tabular}

(Figures in parenthesis are standard deviation, sample size and actual duration in days that the fuelwood would last)

Source: Jama et al, (2008)

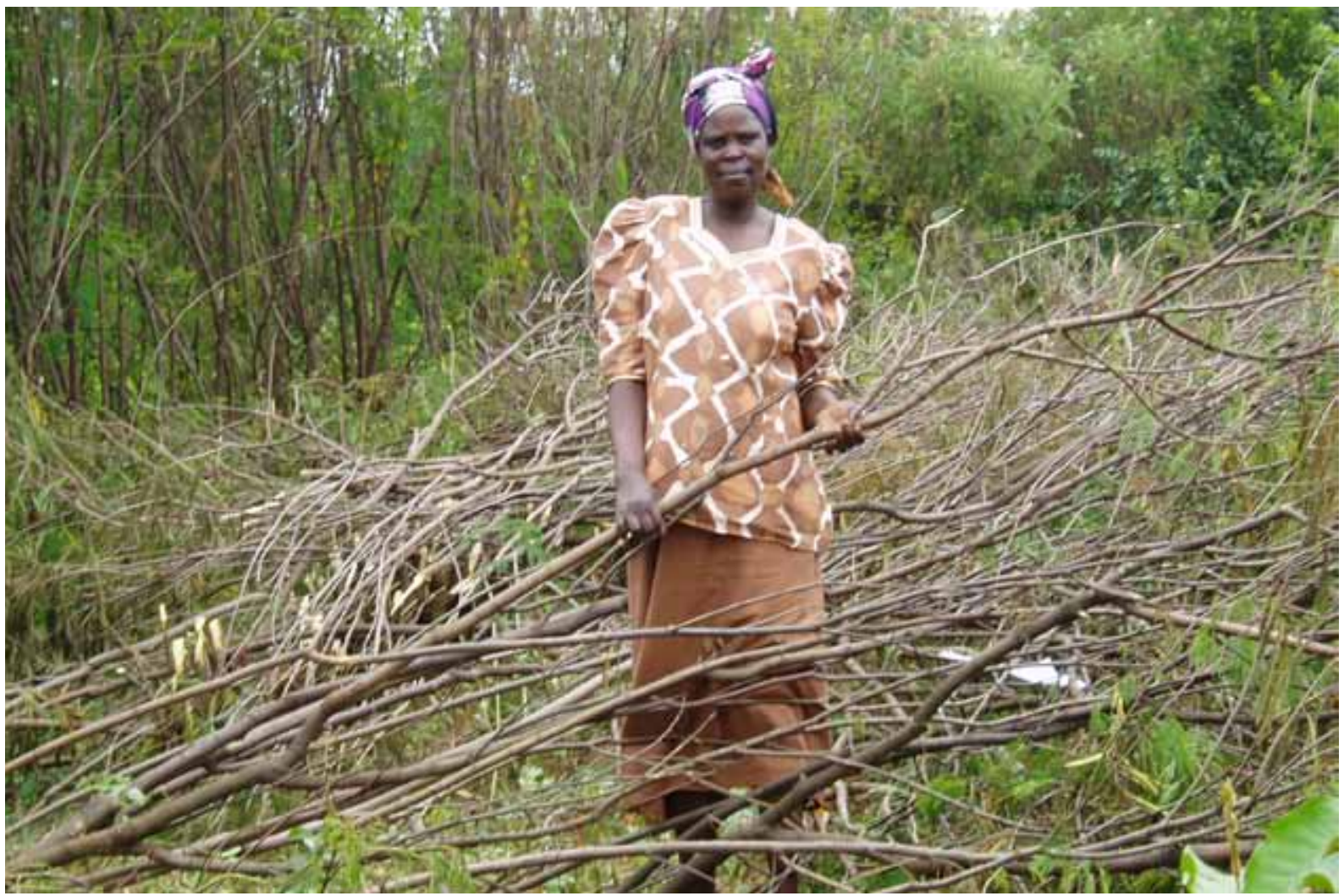

Photo 8: A farmer in western Kenya harvesting fuelwood from an improved fallow plot (E. Kiptot) 
Table 23: Predicted length of period that firewood harvested from a 0.25 ha plot would last a typical household in western Kenya

$\begin{array}{lll}\text { Fallow species } & \text { Fallow period } & \text { Predicted duration } \\ \text { C. grahamiana } & 6 & 340.6(0.9) \\ & 12 & 299.3(0.8) \\ \text { C. paulina } & 18 & 780.0(2.1) \\ & 6 & 389.1(1.1) \\ & 12 & 682.8(1.9) \\ \text { T. candida } & 18 & 859.7(2.4) \\ & 6 & 548.8(1.5) \\ & 12 & 777.7(2.1) \\ \text { T. vogelli } & 18 & 1173.1(3.2) \\ & 6 & 268.5(0.7) \\ & 12 & 564.1(1.5) \\ & 18 & 697.191 .9)\end{array}$

Values in brackets in the last column represent the number of years from 6, 12 and 18 months old fallows would last a typical western Kenya household.

Source: Jama et al (2008)

$7 \%$ being controlled by the head of the household. According to Schreckenbreg (2004), income from kernel sales in Benin varied from US\$ 7-36 per annum which for many women was sufficient to cover a substantial part of their annual expenditures. A study by Crélerot (1995) recorded US\$15-35 per annum in south-western Burkina Faso which represents 20-60\% of women's income in rural areas.

Income from the shea tree depends on the amount of kernels collected and the time they are sold. Prices are low at harvest time and poor women normally sell their kernels as soon as they are dry. Those who have other sources of income hold on to their kernel stocks until the prices rise. The increase in price is substantial. For instance, Schreckenberg (2004) reported that during the 1992/93 season, the price of kernels tripled from CFA 17 per kg at harvest time to CFA 52 per kg just before harvest. Apart from the shea tree, other species that contribute significantly to the total household income in west Africa include Parkia biglobosa, Dacryodes edulis, Ricinodendron heudelotti and Irvingia gabonensis. P. biglobosa fruit known as neré in French is highly commercialized in Burkina Faso with women solely responsible for the sale of fermented seeds. The revenue earned according to Teklehaimanot (2004) is about US\$ 39 per household accounting for $28.8 \%$ of the total income per annum, while in Cote d' Ivoire, neré accounted for $4 \%$ of the total household revenue compared with $2 \%$ from the shea tree.
In Cameroon, farm level production of Dacryodes edulis ranges from US\$ 80-160 per collector with about $41 \%$ sold and the rest used for household consumption (Table 24), although Fondoun and Tiki Manga (2000) cite US\$ 555.23 as the average annual production per household (Table 25). The level of production for Ricinodendron heudelotti is estimated at US\$ 97 per annum while Irvingia gabonensis fruits and kernels are estimated at US\$ 56 and US\$ 101 per annum, respectively. A combination of these makes a substantial contribution to women's income.

Income from G.africanum is quite substantial with an average of US\$2,629 per household per annum



Photo 9: The shea tree in West Africa (ICRAF photo archive) 
(Table 25). The fact that $G$. africanum is collected throughout the year gives women a constant supply of cash. This income is quite significant to women as they do not have access to cocoa which belongs to men. In addition to income from the sale of fruits, nuts, butter, a substantial proportion of indigenous fruit products is also consumed by households (Table 24). For example, $59 \%$ of D. edulis is consumed by the household (Ayuk et al, 1999c). Shea butter, on the other hand, is a major ingredient in most kitchens in semi-arid west Africa while Irvingia gabonensis kernels are used as an essential sauce ingredient in southern Cameroon. The fermented seeds of Parkia biglobosa are ground into a pungent nutritious spice normally added to soups and stews throughout west Africa. The pulp is used to make drinks, green pods eaten as vegetable during the dry season and also used for medicinal purposes (Teklehaimanot, 2004).

In Tabora, Tanzania, indigenous fruits are consumed in large quantities with $44 \%$ of farmers getting it from natural forests while $36 \%$ buy from the market (Oduol et al, 2006). Women participating in a collaborative project managed by the Tumbi Agricultural Research and Training Institute (ARI-Tumbi), ICRAF, the Tanzanian Women Leaders in Agriculture and Environment (TAWLAE) and the Small Industries Development Organization are generating income through processing and selling of jam, wine and juice. They are earning between US\$ 12 to US\$ 30 per week through sale of juice. Selling of wine gives them an average of US\$ 13 per week (Oduol et al, 2006). The extra money women earn is used to improve the welfare of the family by paying school fees (29\%), buying clothes $(21 \%)$, purchase of food $(17 \%)$, domestic use $(18 \%)$, poultry $(2 \%)$ and others $(5 \%)$ (Oduol et al, 2006).

In addition to benefiting from the sale of indigenous fruits and vegetables, having an on-farm supply of wood products is beneficial to women in many ways. In Tabora region of Tanzania, farmers appreciated the fact that they get wood for construction, fuelwood for domestic use and tobacco curing, while others noted that the leguminous trees improve soil fertility (Oduol et al, 2006). Oduol et al (2006) reported that farmers with woodlots save between 15-180 minutes of the whole day they used to spend to get the same quantity of wood. Another study undertaken by Chikoko (2002) in Malawi on the perceived benefits of woodlots by gender showed both women and men received multiple products from woodlots with no significant difference between male-headed and female-headed households (Table 26). Fodder, medicine, fuelwood and food are the responsibility of women while poles and timber are perceived to be men's responsibility.

Another way of assessing benefits from woodlots is by looking at total income per household in a year from the sale of woodlot products (Table 27). The difference

Table 24: Mean annual production (kg/collector) and annual value of production (CFA/collector) of Ricinodendron heudelotti, Dacryodes edulis and Irvingia gabonensis nuts and fruits in Lekié, Cameroon

\begin{tabular}{|c|c|c|c|c|}
\hline \multirow[t]{3}{*}{ Variable } & \multicolumn{4}{|c|}{ Species } \\
\hline & \multirow[b]{2}{*}{ Nuts } & \multicolumn{2}{|c|}{ Irvingia gabonensis } & \multirow{2}{*}{$\begin{array}{l}\text { Dacryodes edulis } \\
\text { Fruit }\end{array}$} \\
\hline & & Fruit & Seeds & \\
\hline Total production & 48 & 112 & 32 & 619 \\
\hline Sales & $20(43 \%)$ & $23(21 \%)$ & I5 (46\%) & $25 I(4 I \%)$ \\
\hline Consumption & $22(45 \%)$ & $54(48 \%)$ & 17 (54\%) & 367 (59\%) \\
\hline Other (gifts ) & $6(12 \%)$ & $35(31 \%)$ & $0(0 \%)$ & $0(0 \%)$ \\
\hline \multicolumn{5}{|c|}{ Value of production (beginning } \\
\hline of season) & 20160 & 14560 & 22560 & 80470 \\
\hline (middle of season) & 11280 & 4480 & 9600 & 40235 \\
\hline (end of season) & 17520 & 8960 & 18720 & 77375 \\
\hline
\end{tabular}

US $\$=500$ FCFA (1996)

Figures in parenthesis are percentages of total production

Source: Ayuk et al, 1999a; Ayuk et al, 1999b; Ayuk et al, 1999c 
in monetary benefits between households along gender lines is clear; male-headed households earn over three times as much income from the sale of woodlot products as female-headed households. This difference according to Chikoko (2002) may be attributed in part to the number of trees in a woodlot. Womenheaded households on average have half as many trees (Table 12) but only $30 \%$ as much income as men and therefore may not have enough to even meet household needs. Another explanation could be that men in male-headed households are attracted to woodlots because of the commercial aspect and would therefore sell the products regardless of the household fuelwood situation. This aspect requires further investigation.

In summary, women receive substantial benefits, both cash and in kind, from agroforestry products and services that are considered to be subsistence by men. These include indigenous fruits and vegetables, fodder, soil fertility improvement and firewood. Income from sale of indigenous fruits and their products in west and southern Africa is significant to women because they are able to control it. In addition, having an on-farm supply of fuelwood and fodder frees up women's labour for other productive activities.

Table 25: Use and annual revenue of $G$. africanum in the humid lowlands of Cameroon

\begin{tabular}{llll} 
Regions & $\begin{array}{l}\text { Average quantity harvested } \\
\text { and sold per month }\end{array}$ & $\begin{array}{l}\text { Average unit price } \\
(\mathrm{US} \$)\end{array}$ & $\begin{array}{l}\text { Average annual revenue/ } \\
\text { household }\end{array}$ \\
Centre & $44,000 \mathrm{~g}$ & 0.0046 & $1,900.8$ \\
East & $44,000 \mathrm{~g}$ & 0.03 & 950.4 \\
South & $\mathrm{II}, 000 \mathrm{~g}$ & 0.0055 & 726 \\
Littral & $66,000 \mathrm{~g}$ & 0.0045 & $3,564.0$ \\
South-west & $55,000 \mathrm{~g}$ & 0.0091 & 6,006 \\
Mean & & & $2,629.44$ \\
\hline
\end{tabular}

Note: I seed=6.90 g; I packet of fresh leaves = I $10 \mathrm{~g}$

Source: Fondoun and Tiki-Manga (2000)

Table 26: Perceived benefits from woodlots in Malawi by gender of household head



Farmers rated the benefits on a five point scale; with five very beneficial and I not beneficial. Figures in parenthesis are sample size and standard deviation

*as reported by women; **as reported by men

Source: Chikoko (2002) 
Table 27: Sum total of income from sale of woodlot products in Malawi

Household type Malawian Kwacha (MK)

Female-headed households $(n=25) \quad 408.60$

Male-headed households $(n=28) \quad 1480.18$

MK $79.00=1$ US $\$$

Wood products sold were firewood, poles, whole trees and timber.

Source: Chikoko (2002)

\subsection{Do women have access to agroforestry information?}

Empirical evidence from the 1990s and recent literature have documented gender disparities in ability to access agricultural information (Saito and Wildermann, 1990; Quisumbing, 1996; Katungi et al, 2008, Meinzin-Dick et al, 2010; Peterman et al, 2010). Access to agroforestry information is no exception; fewer women than men are reached. For instance, a study to determine the effectiveness of various dissemination methods in reaching men and women farmers to advise them about managing calliandra fodder shrubs on farms in central Kenya, Wanyoike (2001) noted that fewer women than men had received at least one extension visit (Table 28). When he categorized farms by the gender of the manager, it was found that about $10 \%$ of jointly managed farms and male managed farms had received at least one visit compared to only $5 \%$ of female managed farms. This bias against women has been attributed to several factors. First, socio-cultural barriers inhibit extension agents, $80-95 \%$ of whom are men (UNEP/GRIDArendal, 2008) from communicating with female farmers. Second, there is a general perception that since men are the decision makers, any extension message should be passed to them (Saito and Widerman, 1990;

Table 28: Extension farm visits on calliandra in different gender categories of households in Embu district, Kenya

\begin{tabular}{|c|c|c|c|c|c|c|}
\hline \multicolumn{7}{|c|}{ Frequency of visits } \\
\hline & $\begin{array}{l}\text { Proportion of } \\
\mathrm{HH} \text { visited }\end{array}$ & Never (count) & Once (count) & Twice (count) & $\begin{array}{l}\text { Three or } \\
\text { more (count }\end{array}$ & Total HHs \\
\hline All farm households & 9 & 273 & 20 & 2 & 5 & 300 \\
\hline $\mathrm{MHH}$ & 10 & 246 & 19 & 2 & 0 & 272 \\
\hline MMF (De facto) & 6 & 53 & 4 & 1 & 1 & 59 \\
\hline JMF & 10 & 33 & 2 & 0 & 0 & 34 \\
\hline \multicolumn{7}{|l|}{$\mathrm{FHH}$} \\
\hline FMF (De jure) & 4 & 27 & 1 & 0 & 0 & 28 \\
\hline $\begin{array}{l}\text { All FMF (De facto+de } \\
\text { jure) }\end{array}$ & 5 & 59 & 3 & 0 & 0 & 62 \\
\hline
\end{tabular}

Legend: $M M F=$ Male managed farms, FMF=Female managed

farms, JMF=Jointly managed farms

Source:Wanyoike (200I) 
Meinzen-Dick et al, 2010). This latter assumption has been shown by Abbas (1997) and Gladwin et al (2001) to be flawed. This is because households are complex institutions with different roles and responsibilities and members may have separate spheres of decisionmaking with reference to production, income and expenditures. Third, there is still a perception in some places, surprising though it may seem, that women are not farmers (Meinzin-Dick et al, 2010).

For the few women who are able to access extension information, Saito and Wildermann (1990) report that since some of them lack basic education, their ability to use technical information is compromised. Basic education places farmers in a better position to perceive potential benefits of adopting innovations. Women's literacy level as a proportion of men's levels are increasing, reaching $63 \%$ in west and central Africa over the period 2000-2004 and 85\% in east and southern Africa (UNESCO, 2007). However, women's literacy levels are still low: Benin (48\%), Cameroon (36\%), Tanzania (33\%) and Zimbabwe (15\%) (UNESCO, 2002). This has implications on the adoption of agroforestry innovations. But the lack of education does not necessarily prevent farmers from adopting new practices. In Embu district of Kenya, Wanyoike (2001) noted that women who were using calliandra fodder shrubs had a lower level of education than men; an average of seven years of schooling for men and two years for women. Wanyoike (2001) also

\begin{tabular}{|c|c|c|}
\hline \multirow[b]{3}{*}{ Activity } & \multicolumn{2}{|c|}{$\%$ of respondents } \\
\hline & Male & Female \\
\hline & 1995 & 1995 \\
\hline Meetings ('barazas') & 83 & 33 \\
\hline Field days & 77 & 38 \\
\hline Education tours & 59 & 22 \\
\hline Agroforestry rallies & 49 & 23 \\
\hline Training on agroforestry & 38 & 13 \\
\hline Video shows & 52 & 30 \\
\hline Agricultural shows & 62 & 33 \\
\hline
\end{tabular}

Source: KWAP (1996) found considerable differences in male and female attendance in extension events. For example, a higher proportion of farmers in male-headed households $(20 \%)$ than in female-headed households (8\%) had attended field days. This is further confirmed by KWAP (1996) in a survey on gender participation in mass awareness activities in Uasin Gishu district, Kenya, where men participated in about twice as many mass awareness activities as women (Table 29). According to Wanyoike (2001) men who had not attended cited lack of awareness of the time and venue of the field days as the main reason while women cited lack of time as they are normally involved in household chores all day long.

In summary, men receive many more extension visits than women and participate in more field days and other extension activities off the farm. The reasons for women's low involvement is the bias of extension workers towards men, socio-cultural barriers limiting communication between male extension workers and women, and women's lack of time for participating in extension activities off the farm.

\subsection{Agroforestry product markets: are women involved?}

Although many studies have reported that women are often involved in marketing of agroforestry products that are considered a domain for women and children such as indigenous fruits, spices, herbs and local vegetables, their involvement is mostly confined to the small retail trade. In a study of production and marketing of D. edulis (Safou) in Cameroon, Awono et al (2002) noted that women dominate the collection of the fruit and are also responsible for taking it to the market where they dominate the retail trade (95\%). Men concentrate on wholesale trade (71\%) (Figure 6). This gender difference is confirmed by Schreckenberg (2004) who found that women in Benin dominated the retail trade of the shea kernels and shea butter. In Cameroon, Kanmegne et al (2007) found out that in the trading of $G$. africanum, $93 \%$ of retailers were women. The few men involved dominated the wholesale trade, as it requires significant capital which men can obtain after selling cocoa. In addition, wholesale trade involves less market time but often a lot of travel which many women cannot undertake due to household responsibilities.

But even where women are involved in production and collection of agroforestry products, their involvement 
in marketing may be limited by the mode of transport used to transport agroforestry products. For example, in Tanga, Tanzania, where farmers collect calliandra leaves for processing into leaf meal, 11 of 17 collectors were women whereas 10 of 11 traders were men.

Bicycles were usually required for trading but were not considered culturally acceptable for women (Franzel et al, 2007).

A further analysis of marketing of $D$. edulis revealed that women traders received lower marketing margins per sack than men: US\$ 6 for women against US\$ 7 for men (Awono et al, 2002). This may be because men sell more sacks per transaction than women. Most women traders do not obtain enough capital to increase their stocks of $D$. edulis. Furthermore, examining the relationship between marketing margins and level of
(Figure 7). Some of the products, such as shea butter, marula and baobab have very long value chains involving wholesaler, traders, exporters, importers and manufactures who rake off much of the profit leaving poor rural women collectors with very little income.

Women who are involved in marketing agroforestry products are often at the lower end of the marketing chain and are usually the least informed about market prices and consumers' preferences. Having little access to market information increases their vulnerability to brokers and middlemen who take advantage of their ignorance by offering very low prices, as they have no means of bargaining for better prices. Moreover, if women lack information about the product characteristics that consumers prefer, they will be unable to earn premium prices for their products.



Source: Awono et al (2002)

Figure 6: Involvement of men and women in marketing D.edulis (Safou) in Southern Cameroon

education showed that the highly educated traders are more successful. Given that women's literacy level is lower than men, they are relatively disadvantaged. Traders who are highly educated have access to better market information such as marketing channels and prices and are therefore in a better position to make informed decisions on where to purchase and sell stocks without making any losses.

Since women involved in marketing of agroforestry products are confined to retailing (the early stages of the value chain) they fail to benefit equitably from the growing national and international markets
New market information systems are coming up throughout Africa to address the above problems. For instance, in Burkina Faso, Mali and Niger, a scheme run by NGO Afrique Verte has launched modern ICT-based trading exchanges for cereals using cell phones, so that producers can compare supply and demand in different areas (CTA, 2009). Use of cell phones requires farmers to use short message services (sms) by sending their requests and automatically they receive updates on market prices. Another useful tool is local radio. Local radio is a powerful medium for passing information and is increasingly used to 


\section{Shea butter value chain ( Burkina Faso )}

Marketing chain of Shea Butter in Burkina Faso

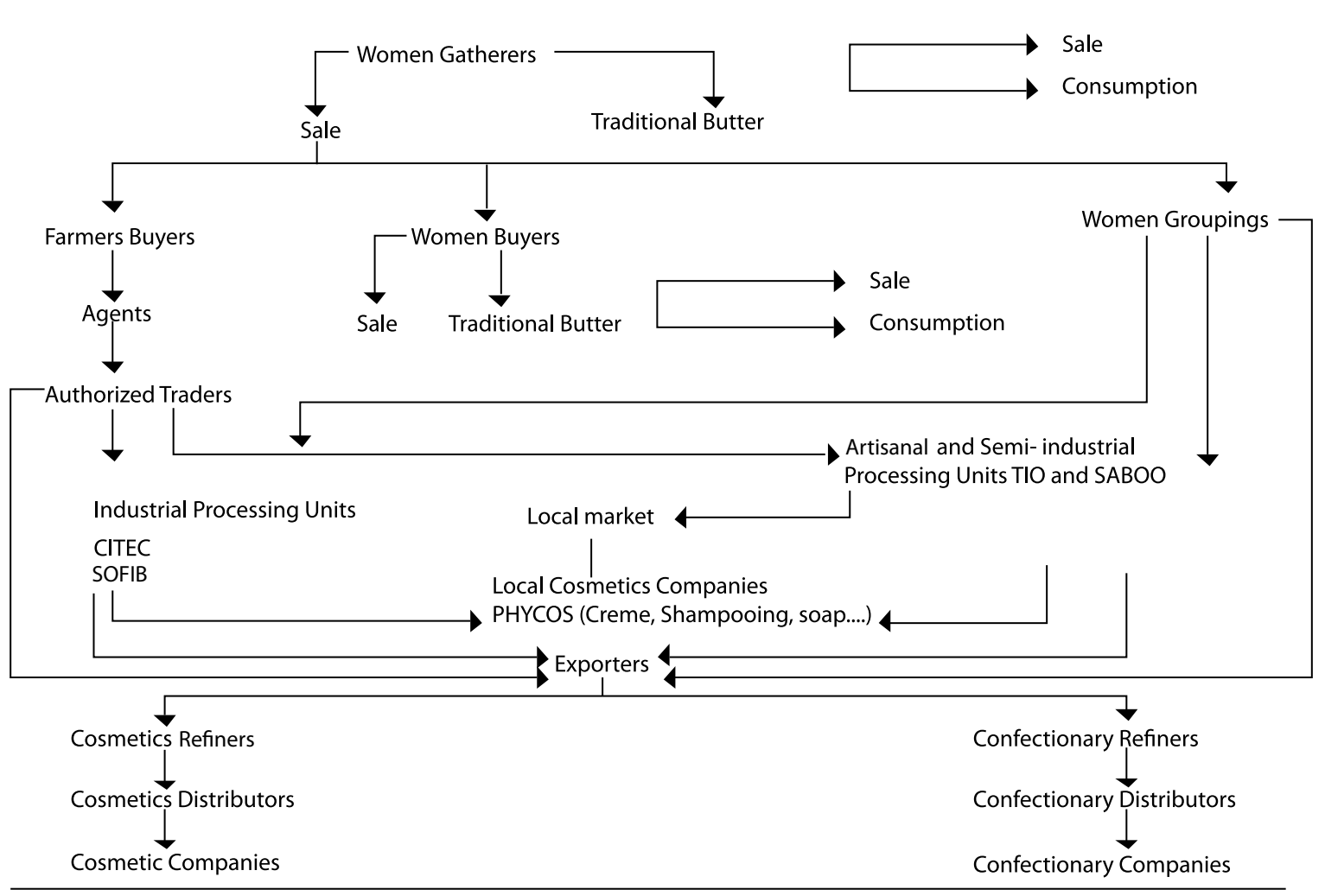

Source. Carr et al. (2000)

Figure 7: Marketing chain of shea butter showing the level at which women are involved

provide market information in many parts of Africa. Examples of countries that are using ICT (radio, phones or e-mail) to reach farmers are Kenya through the National Farmers Information Service and Kenya Agricultural Commodity Exchange, the National Producers' Association in Cote d'Ivoire, Malawi Agricultural Commodities Exchange in Malawi and Family Alliance for Development and Cooperation in Karagwe district, Tanzania (CTA, 2009; Gakuru et al, 2009).

But just as extension systems are generally biased towards men, market information systems also appear to primarily serve men. For example, the Malawi Agricultural Commodity Exchange provides price information and trade facilitation services via sms but only $20 \%$ of the users are women (Manda, 2009). Similarly, women make up only $21 \%$ of the beneficiaries in the Market Information Systems for
Traders' Organizations in West Africa (MISTOWA) project (Debrah, 2009). The reasons for the gender imbalance are not clear; it may be because fewer women than men are involved in trade, because fewer women than men are aware of the service or because fewer women have cell phones.

In summary, where women are involved in marketing agroforestry products, they are usually confined to the small retail trade while men dominate the wholesale trade. Women traders receive lower marketing margins than men. This discrepancy is attributed to the fact that men usually have more stock than women, because they have access to more capital. Just as extension systems are generally biased towards men, market information systems also appear to primarily serve men. That women's literacy level is lower than men's presents another important disadvantage in marketing. 


\subsection{How can we promote efficient participation of women in agroforestry with greater benefits accruing to them?}

This review provides ample evidence that agroforestry has the potential to offer substantial benefits to women across Africa. While women's needs vary across locations, one point is clear; they are attracted to agroforestry because of minimal inputs needed for most agroforestry practices, particularly with regard to cash, and the substantial benefits, in terms of food, fuelwood and other products and services that they get. Despite the fact that agroforestry is advantageous to women, this review has shown that they face several limitations, which hinder them from benefitting from agroforestry enterprises. This section proposes various technological, policy and institutional recommendations to promote efficient participation of women in agroforestry with greater benefits accruing to them. It focuses on recommendations which affect agroforestry in particular and which are based on research reported in this paper. Beyond the constraints specific to women and agroforestry, there are important structural problems in the agricultural sector, e.g., low returns, lack of investment, and weak tenure rights, that affect both men and women. This section does not address these problems or make recommendations which are more applicable to agriculture in general. For example, the need for better roads or market infrastructure are not discussed.

Recommendations will of course need to be locationspecific and based on the households' needs and circumstances. Household members will need to be involved in the planning, implementation, and evaluation of the various interventions. Participatory methods for doing this are well documented (Ashby, 1990; Gonsalves et al, 2005).

\subsection{Technological interventions}

Domestication of important agroforestry species Many tree products that benefit women are collected from wild populations in forests, woodlands/ rangelands, parklands or on farms. For centuries this collection has not had a negative impact on the environment. However, growing population and trade has increased the demand for these products and deforestation has reduced their supply. For instance, shea butter is not only used in kitchens in West Africa, but is also used in the pharmacology, chocolate and cosmetic industries in Europe and USA (Teklehaimanot, 2004). This increasing demand has led to degradation of the parkland resources in general and $P$. biglobosa and $V$. parodoxa in particular. Evidence of degradation has been shown in terms of reduced densities and population structure (Gijbers et al, 1994). Apart from fruits/kernels, the demand for $G$. africanum leaves is also very high both locally and internationally. A recent survey on the marketing of $G$. africanum revealed that 3600 tonnes is shipped annually to Nigeria from Cameroon and exported to European countries and the USA (Asaha et al, 2000). To meet the demand, women walk long distances to remote parts of Cameroon in search of it. During harvesting, the trees that $G$. africanum vines grow on are often felled, destroying the resource. In some cases harvesters uproot the whole vine. The high demand coupled with unsustainable harvesting methods is leading to scarcity of $G$. africanum and other valuable agroforestry tree products.

Farmers have little or no knowledge of propagation and management of most indigenous species; hence, the "participatory domestication" initiatives led by ICRAF and national partners are critical for sustaining farmers and women's incomes from these species as well as for preserving the genetic diversity (Tchoundjeu et al, 2008). Farmers in west Africa are already domesticating tree species such as $V$. parodoxa (shea tree), D. edulis, I. gabonensis and P. biglobosa (Degrande et al, 2006; Lovett and Haq, 2000; Schreckenberg et al, 2002; Leakey et al, 2004). Farmers are knowledgeable about the use and conservation of these high value indigenous species as they have been domesticating them for years. They have been doing it by selectively retaining important trees when clearing land for agricultural production and retaining particular trees for their large fruit size as well as other characteristics such as taste and yield. However, farmers can only achieve maximum benefits if there is appropriate technical support. Promoting participatory domestication will enable the integration of local knowledge with scientific knowledge to move these valuable species 
into appropriate farming systems. The end product of such an initiative would be appropriate propagation methods with low labour and capital requirements and cultivars that meet a range of market requirements such as fruit with specific size, taste, and maturity periods so that farmers, especially women, can have a year round flow of cash from agroforestry products.

In addition to cultivars that meet market requirements, women are constrained when it comes to harvesting because most trees are very tall and they therefore have to rely on men to harvest, but often at a fee. Those women without assistance end up relying on fallen fruit whose quality in most cases is compromised. Cultivars are needed that are of reasonable height so that anyone, even children, can harvest without having to climb a tree. An additional hindrance is the taboo that prohibits women from climbing certain trees in West Africa. Smaller trees have the additional benefit of taking up less land, a resource which is often limiting for women farmers.

\section{Development of post-harvest storage methods} Many agroforestry products, particularly fruits and vegetables, have a very short shelf life. For instance, D. edulis fruits last only five days, which makes it very difficult for women to market them for a longer period. They therefore end up disposing of their products at a throw-away price to avoid incurring huge losses. Appropriate techniques for improving the post-harvest quality of on-tree and off-tree ripened fruits are needed such as regulation of harvest time to maximize post harvest fruit colour and sweetness; improving the artificial ripening under different post harvest incubation regimes and extended shelf-life with and without refrigeration. In addition, wholesale traders normally store their produce in large heaps on the open ground with no protection from rain, sunshine and wind. The bulk storage affects the quality of the fruit because those at the bottom of the heaps are squashed while those at the top are baked by the sun thereby leading to huge loses (Karaan et al, 2005). Development of low-cost storage boxes would go a long way in helping reduce losses incurred.

\section{Development of appropriate agricultural and processing techniques}

The problem of limited shelf life can also be addressed through processing which ensures supplies for periods of shortage and improves product quality. Where there is market demand for such products, marketing of processed products can also increase women's incomes. Most women still use ancient processing techniques that were passed down to them through generations.
For example, Teklehaimanot (2004) reported that $80 \%$ of shea butter in Mali and Burkina Faso is made traditionally. Traditional extraction techniques for shea butter are time consuming and physically strenuous; they also require huge amounts of fuelwood and water and have a low extraction efficiency, creating a significant drain on these scarce resources. Becker and Staatz (2003) estimated that for the extraction of butter from each kilogramme of dried nuts, $2.6 \mathrm{~kg}$ of firewood is needed as well as 3.6 litres of water. The preparation of fermented seeds of néré ( $P$. biglobosa) in Burkina Faso, compressing leaf meal in Tanzania, and the extraction of $R$. heudelotii nuts in Cameroon are other examples where women's traditional processing methods are laborious. Simple low cost techniques for processing in these cases could help women reduce labour requirements and wastage while improving productivity and maintaining nutritive quality. Tools and practices to help women reduce the time taken and drudgery will tremendously free women's time which can otherwise be used in other productive activities such as attending extension sessions. Potential processing techniques need to be screened for their profitability and sustainability.

Development of efficient agricultural and processing techniques also needs to be accompanied by capacity building. Women need to develop their business and marketing skills in addition to processing techniques. Key skills required include; how to assess demand, develop business plans, negotiating skills and record keeping. A key issue is whether training should involve individuals or groups. This depends on the particular situation. Experience from the ARI-ICRAF-TAWLAESIDO fruit project in Tabora, Tanzania showed that training groups is more cost efficient. Furthermore, even when group enterprises fail, capable individuals carry on with the activities using the skills acquired (ARI-Tumbi, 2006). The project has not only imparted processing, marketing and business skills, but also empowered women financially and the incomes of families have been raised by an average of Tsh 30,000 a month (US\$28.5). Since the assessment on which these findings were based was done at the end of the project, it is important that follow up assessments be conducted to document if the impacts were sustained.

\section{Development of new products}

Once women can effectively compete in producing raw and processed materials for local markets, they can seek opportunities in developing new products. For women to compete favourably and also have an edge, they need to move away from the traditional products into a diversity of high value new products such as oil, soap, juices, body lotions, wine, and leaf 
meal. Such new products need to be carefully assessed however, taking into account projections of risk, profitability, competition, and economies of scale. This diversification can often be done using the same raw materials. For instance, women engaged in calliandra fodder production in the high potential areas of eastern Africa, can also process calliandra leaf meal for sale in agrovet shops and to other dairy and poultry farmers as a fodder supplement as is already being done in Tanga, Tanzania with Leuceana leucocephala. Producers, who are usually women, collect leuceana from the wild, dry and crush the leaf into leaf meal which is then packed into gunia bags and sold to owners of stall-fed dairy and poultry enterprises (Franzel et al, 2007). Women in southern and west Africa are already producing various products from indigenous fruits but the range needs to be increased so that they have an edge in marketing. In East Africa, product development from indigenous fruits is still in its infancy and therefore efforts need to be stepped up to empower women to venture into new products which will enable them diversify their incomes.

\subsection{Policy interventions}

An enabling policy environment is critical in making sure that agroforestry benefits women. At the national level, governments in developing countries need to acknowledge that women are the backbone of agriculture, yet they face many challenges, that limit their production. Gender sensitive policies need to be put in place. This section highlights major policy recommendations, many of which are also relevant to other sectors which if put in place, will go a long way in enabling women benefit fully from agroforestry. The recommendations are grouped into three key areas; extension services, access to market information and microfinance.

\section{Access to extension services}

The weakness of many extension systems, particularly public ones, has been widely acknowledged (Davis, 2008). The traditional linear model, with the extension agent as a trainer is being replaced by pluralistic models, with the agent primarily acting as a facilitator, networker and linker (World Bank, 2006). To ensure that extension services benefit women, deliberate gender sensitive interventions need to be put in place including;

- Training more women extension officers, particularly to serve communities that have strong traditions that prohibit male extension officers from interacting with women farmers.
- Targeting women's groups for assistance. This review has shown the effectiveness of targeting such groups as a means of disseminating information and technology to women.

- $\quad$ Finding out from women which periods of the season and days of the week they are free to meet and holding meetings, field days and seminars at these times.

- Holding separate meetings for men and women.

- Organizing video show sessions for women who are not able to participate in tours.

- Ensuring that at least half of those who participate in any activity are women.

- Ensuring that extension activities address different interest groups. This review has shown that women are more interested in products such as fruits, fuelwood and vegetables while men are more inclined towards timber and poles. That women and men have different planting objectives and evaluation criteria means that they require different extension approaches.

We emphasized the need for helping women farmers develop new products but there is still a lot of potential in helping them exploit existing products such as indigenous fruits, vegetables, and other non-wood forest products. Information on such enterprises remains scarce. This paucity of information can be blamed in part on the split between agriculture and forestry curricula where traditional foresters are more concerned with trees for timber whereas agriculturalists are more inclined towards traditional agricultural crops and conventional exotic fruit species such as oranges and mangoes. Since non-wood agroforestry products play a significant role in improving the livelihoods of poor farmers, who are mainly women, it is imperative that training institutions and policy makers integrate these species and their products in the mainstream extension packages as part of a basket of options for improving livelihoods.

\section{Access to market information}

As noted above, the rise of market information systems based on ICTs offers great potential for improving smallholder access and returns. However, to our knowledge, none of the systems have programmes specifically targeting market information to women. Perhaps some type of public-private partnership is required in which a donor or government project subsidizes the targeting of market information services 
to women and services covering neglected crops marketed by women, such as the tree fruits, oils, and vegetables discussed in this review. Such a programme might involve subsidizing the provision of handsets to women or specialized training on how to use the service. Knowledge is power and with access to market information, women farmers can greatly reduce losses due to wastage due to lack of buyers as they will be able to make informed decisions about when to produce, what to produce, for whom to produce and when and where to sell their produce. They will also have strengthened bargaining power and save precious time and money as they will only leave their homes when they are sure they have a buyer for their produce.

\section{Improving women's access to finance from micro- credit institutions}

According to World Bank (2007), women in developing countries receive less than $10 \%$ of available credit. This is due to lack of land title deeds, which are normally used as collateral in rural areas. For women to access financial credit, governments need to intervene to encourage the development of rural micro-credit institutions whose regulations are suitable for women. Intervention can be in the form of accepting other forms of collateral such as machinery, furniture and any other tangible assets that women may own. The capacity of existing social organizations such as women groups need to be strengthened so that they may access credit individually but use the group as collateral. A good example of such an innovative approach in Kenya is known as Fanikisha and is being implemented by Equity Bank which partnered with UNDP, UNIDO, ILO and Ministry of Finance in 2008. The aim is to increase women's access to credit. The programme targets women who lack assets that can be used as collateral (UNDP, 2010). By accessing credit, women would be in a better position to adopt the use of improved practices and technologies and operate bigger businesses thus increasing their contribution to household income which may consequently improve their decision-making power in households. A study by Ishani (2009) showed that when women contributed to household income, the balance of power shifted, as they had more voice in (joint) decision-making.

Finally, instead of providing free equipment to women's groups, as many NGOs and projects do, institutions would be better off helping the groups to link up with financial institutions and, if necessary, subsidizing the credit that groups receive to purchase the equipment themselves. This approach helps ensure that a proper business plan for using the equipment is prepared, and that the NGOs and projects will be able to serve more groups since they are only paying a portion of the costs of the equipment (Faulkner et al, 2009).

\subsection{Institutional interventions}

Women producers in sub-Saharan Africa are trapped at the production end of the value chain. This disadvantaged position limits their control over and returns from the productive process. For women to come out of this trap, governments, NGOs and the private sector need to intervene by assisting women to form and strengthen farmers' groups or associations and linking them up with markets. By engaging in collective action women would be able to gain a more powerful position in the value chain. Such a powerful position would help women to:

- Achieve stronger bargaining power

- $\quad$ Sell in bulk

- Purchase inputs in bulk

- Ensure a sustainable supply of products

- $\quad$ Reduce transaction costs

- Attract more and larger buyers

- Access outside resources, such as extension and development assistance

- Access fair-trade and other certified markets, and above all

- Contribute to the policy formulation process.

Strengthening women's groups at the community level is critical, as is helping such groups to federate across larger areas. There are several examples in the literature where women have come together and through the facilitation of various institutions, are currently reaping the benefits of agroforestry. A good example in southern Africa is Phyto Trade Africa that has been helping Southern Africa's natural products industry to achieve rapid growth while ensuring its long-term sustainability and social equity through product development, market development and supply chain development. For instance in 2006, 30,000 producers in seven southern Africa countries (93\% women) sold their raw materials to Phyto Trade Africa (Phyto Trade, 2007). In Burkina Faso, 400,000 rural Burkinabe women have been working with the UN Development Fund for Women (UNIFEM) and the Centre Canadien d' étude et de Coopération Internationale (CECI), a Canadian NGO which has been facilitating them to process and market shea nuts. UNIFEM linked these groups to a French cosmetics company known as LOCcitane that purchases shea butter directly from the Union des Groupments Kiswendsida (UGK), a network of more than 100 women groups. This ensures that a greater share of the revenue goes 
to producers who are women instead of middlemen. In addition the company provides training in quality control and pays for the shea butter in advance

(Harsch, 2001).
These are just but a few examples of how institutional interventions can promote women from the lower end of the production chain to a position where they have control over the production, processing and marketing of their products. 


\subsection{Conclusion}

This review has shown that agroforestry offers substantial benefits to rural women in Africa, primarily because it requires fewer resources, particularly land and capital, than alternative enterprises. But nevertheless, women's participation is low in enterprises that are considered men's domain and high in enterprises that are considered to have little or no commercial value such as collection and processing of indigenous fruits and vegetables. Fodder production, soil fertility management and woodlot production are other agroforestry practices that women are involved in; however, their degree of involvement relative to men is low when measured by the area they allocate to these activities and the number of trees they plant. In relation to marketing of agroforestry products, women are confined to the lower end of the value chain (retailing) which limits their control over and returns from the productive process. For women to come out of this trap, various policy, technological and institutional interventions are needed.

Several promising approaches to improving women's benefits from agroforestry are documented in this paper. For example, while the enterprises in women's domain are often low-value, there are cases where collective action and marketing interventions have helped raise values and incomes, as with indigenous fruit processing and marketing in Tanzania. Further, while extension services are biased towards men, the targeting of women through women's groups has helped raise the proportion of women beneficiaries to about half, as in the case of fodder shrubs in Kenya.

This review was guided by seven research questions which were tackled accordingly based on data available. However, most subjects could not be addressed adequately due to lack of data. There are few studies on gender and agroforestry and small samples sizes often restrict the possibility of generalizing from them.
Filling these gaps will enable the scientific community, policy makers and development practitioners to understand fully how women across Africa are involved in agroforestry and thereby facilitate the development and implementation of projects that take into account gender issues. Key research areas for further investigation include:

- Measuring the actual income women receive from agroforestry, relative to non-agroforestry enterprises and also relative to what men earn.

- Assessing the effectiveness and impact of alternative dissemination methods on women's participation and benefits.

- Determining how different categories of women (e.g., female-headed households and women in male-headed households) benefit from agroforestry.

- Identifying success stories across Africa and assessing the factors that have contributed to their success and how to replicate them.

- Documenting cultural beliefs and taboos regarding tree planting and how they influence adoption of agroforestry by women across the African continent.

- Determining how to help women to increase their participation in marketing and the amounts they earn from marketing.

- Determining how gender roles influence the women's adoption of agroforestry.

- Assessing how to help women increase their participation in traditional male tree crops such as coffee, cocoa and oil palm. 


\subsection{References}

Abbas, J.D. 1997. Gender asymmetries in intra-household resource allocation in sub-Saharan Africa: Some policy implications for land and labour productivity. In: Haddad, L., Hoddinott, J and Alderman H. (eds). Intrahousehold resource allocation in developing countries: Models, methods and policy. Baltimore, MD: Johns Hopkins University Press for the International Food Policy Research Institute.

Ajayi, O.C., Ayuk, E.T., Massi, C., Phiri, D. and Kwesiga, F.K. 2001. Typology and characteristics of farmers planting improved fallows in Eastern Zambia. Working Paper No. 2. ICRAF Agroforestry Project, Chipata, Zambia.

Ajayi, O.C., Franzel, S., Kuntashula, E. and Kwesiga, F. 2003. Adoption of improved fallow soil fertility management practices in Zambia: synthesis and emerging issues. Agroforestry Systems 59 (3): 317-326.

Ajayi, O.C., Place, F., Kwesiga, F., Mafongoya, P. and Franzel, S. 2005. Impact of fertilizer tree fallows in eastern Zambia. World Agroforestry Centre. Nairobi, Kenya.

Akinnifesi, F.K., Kwesiga, F., Mhango, J., Chilanga, T., Mkonda, A., Kadu, C.A.C., Kadzere, I., Mithofer, D., Saka, J.D.K., Sileshi, G., Ramadhani, T. and Dhliwayo P. 2006. Towards the development of miombo fruit trees as commercial tree crops in southern Africa. Forests, Trees and Livelihoods. 16: 103-121.

Akinnifesi, F.K., Kwesiga, F.R., Mhango, J., Mkonda, A., Chilanga, T. and Swai, R. 2004. Domesticating priority miombo indigenous fruit trees as a promising livelihood option for smallholder farmers in southern Africa. Acta Horticulture 632: 15-30.

Amadalo, B., Niang, A., Gathumbi, S. and Jama, B. 1998. Using short duration improved fallows in western Kenya for soil fertility and crop improvement. A research report. Regional Agroforestry Research Centre, Maseno, Kenya.

ARI-Tumbi. 2006. Introduction of indigenous fruit processing technology to rural communities in Tabora, Uyui and Sikonge districts. End of project report. Agricultural Research and Training Institute-Tumbi, Tabora, Tanzania.

Asaha, S., Tonye, M.M., Ndam, N. and Blackmore, P. 2000. State of knowledge study on Gnetum africanum Welw. and Gnetum buchholzianum Engl. A report commissioned by the Central African Regional Programme for Environment. Limbe Botanic Garden Library (11-15).

Ashby, J.A., 1990. Evaluating technology with farmers: A handbook. CIAT Publication no. 187.International Centre for Tropical Agriculture, Cali, Columbia.

Awono, A., Ndoye, O., Schreckenberg, K., Tabuna, H., Isseri, F. and Temple, L. 2002. Production and Marketing of Safou (Dacryodes edulis) in Cameroon and Internationally: Market Development Issues. Forests, Trees and Livelihoods 12: 125-147.

Ayuk, E.T., Duguma, B., Franzel, S., Kengue, J., Mollet, M., Tiki-Manga, T. and Zekeng, P. 1999a. Uses, management and economic potential of Dacryodes edulis (Burseraceae) in the humid lowlands of Cameroon. Economic Botany 53 (3): 292-301. 
Ayuk, E.T., Duguma, B., Franzel, S., Kengue, J., Mollet, M., Tiki-Manga, T. and Zekeng, P. 1999b. Uses, management and economic potential of Irvingia gabonensis in the humid lowlands of Cameroon. Forest Ecology and Management 113: 1-9.

Ayuk, E.T., Duguma, B., Franzel, S., Kengue, J., Mollet, M., Tiki-Manga, T. and Zekeng, P. 1999c. Uses, management and economic potential of Garcinia Kola and Ricinodendron Heudelotii in the humid lowlands of Cameroon. Journal of Tropical Forest Science 11 (4): 746-761.

Becker, M. and Statz, J. 2003. Marketing of parklands products. In: Teklehaimanot, Z. (ed) Improved management of Agroforestry Parkland Systems in sub-Saharan Africa. EU/INCO Final Project Report. University of Wales, Bangor UK.

Bird, N. and Dickson, C. 2005. Poverty Reduction Strategy Papers: making the case for forestry. ODI Forestry Briefing No. 7. ODI, London.

Boffa, J.M., Yaméogo, G., Nikiéma, P. and Knudson, D.M. 1996. Shea nut (Vitellaria paradoxa) production and collection in agroforestry parklands of Burkina Faso. In Leakey, RRB., Temu, A. and Melnyk, M (eds.) Domestication and commercialization of non-timber forest products in agroforestry systems: Proceedings of an international conference held in Nairobi, Kenya 19-23 February.

Böhringer, A. 2001. Facilitating the wider use of agroforestry for development in southern Africa. Development in Practice 11(4): 434-448.

Boserup, E. 1970. Women's role in economic development. Earthscan, London.

Bradly, P. 1991. Woodfuel, women and woodlots. Vol 1. Macmillan, London.

Buyinza, M. and Wambede, N. 2008. Extension for agroforestry technology adoption: mixed intercroppig of Crotolaria (Crotolaria grahamiana) and Maize (Zea Mays L. ) in Kabale District, Uganda. Environmental Research Journal 2 (30): 131-137.

Campbell, B., Luckert, M., Scoones, I. 1997. Local level valuation of Savannah resources: A case study from Zimbabwe. Economic Botany 51: 57-77.

Campbell, B.M.1987. The use of wild fruits in Zimbabwe. Economic Botany 41 (3): 375-385.

Carloni, A. S. 1987. Women in development: AID’s experience, 1973-1985. Volume 1. Synthesis paper. AID. Programme Evaluation Report No. 18. United States Agency for International Development. Washington DC.

Carr, M., Chen M. and Tate. 2000. Globalization and home-based workers. Feminist Economics 6. No. 3.

Chavangi, N. 1994. Cultural aspects of fuelwood procurement in Kakamega District. KWDP Working Paper No. 4. KWDP/The Beijer Institute, Nairobi, Kenya.

Chikoko, M.G. 2002. A comparative analysis of household owned woodlots and fuelwood sufficiency between female and male-headed households: A pilot study in rural Malawi, Africa. A PhD dissertation. Oregon State University, USA.

Cohen, J.M. and Uphoff, N.T. 1980. Participation's place in rural development: Seeking clarity through specificity. World Development 8(3): 213-235.

Cooper, P.M.J., Leakey R.R.B., Rao, M.R. and Reynolds, L. 1996. Agroforestry and the mitigation of land degradation in the humid and sub-humid tropics of Africa. Experimental Agriculture 32: 235-290. 
Crélot, F.M. 1995. Importance of Shea nuts for women's activities and young children's nutrition in Burkina Faso: the case of the Lobi. PhD Thesis, University of Wisconsin, USA.

CTA, 2009. Smart Marketing: Sell more, for better price with ICTs. Spore No. 140: 8-9. April 2009. Technical Centre for Agricultural and Rural Cooperation.

David, S. 1998. Intra-household processes and the adoption of hedgerow intercropping. Agriculture and Human Values 15: 31-42.

Davis, K. (2008) Extension in sub-Saharan Africa: Overview and assessment of past and current models and future prospects. Journal of International Agricultural Extension and Education. 15:3:2008 pp 15-28.

Debrah, K. 2009. Role of ICT-based MIS in enhancing smallholder producers' incomes: the case of the Market Information Systems for Traders' Organizations in West Africa (MISTOWA) project. A paper for presentation at the AGRA Conference: Towards Priority Actions for Market Development for African Farmers. ILRI, Nairobi, 13-15 May 2009

Degrande, A., Shreckenberg K., Mbosso C., Anegbeh, P.O., Okafor, J. and Kanmegne, J. 2006. Farmers' fruit tree growing strategies in the humid forest zone of Cameroon and Nigeria. Agroforestry Systems 67: 159-175.

Doss, C.R. 2001. Designing agricultural technology for African women farmers: lessons from 25 years of experience. World Development 29 (12): 2075-2092.

Epaphra, E. 2001. Assessment of the role of women in agroforestry systems: a case study of Marangu and Mamba in Kilimanjaro region, Tanzania. World Agroforestry Centre. Nairobi, Kenya.

FAO. 2001. The economics of soil productivity in sub-Saharan Africa: Rome, FAO.

FAO. 2006. The state of food insecurity in the world. Eradicating world hunger: taking stock 10 years after the World Food Summit, Rome, FAO.

Faulkner, L., Harrington, J., Levy, D., and The, K. 2009. Commercial opportunities for fruits in Malawi. Working Paper no. 86. World Agroforestry Centre, Nairobi.

Fondoun, J.M. and Tiki-Manga, T. 2000. Farmers' indigenous practices for conserving Garcinia kola and Gnetum africanum in southern Cameroon. Agroforestry Systems 48: 289-302.

Fortmann, L. 1985. The tree tenure factor in agroforestry with particular reference to Africa. Agroforestry Systems 2: 229-251.

Francis, P.A. and Atta-Krah, A.N. 1989. Sociological and ecological factors in technology adoption: Fodder trees in southeast Nigeria. Experimental Agriculture 25: 1-10.

Franzel S., Hitimana, L. and Akyeampong, E. 1995. Farmer participation in on-station tree species selection for agroforestry: A case study from Burundi. Experimental Agriculture 31: 27-38.

Franzel, S. and Wambugu, C. 2007. The uptake of fodder shrubs among smallholders in East Africa: key elements that facilitate widespread adoption. In: Hare, M.D. and Wongpinchet, K. (eds). 2007. Forages: a pathway to prosperity for smallholder farmers. Proceedings of an International Symposium, Faculty of Agriculture, Ubon Ratchathani University, Thailand, 203-222. 
Franzel, S., Arimi, H.K. and F.M. Murithi. 2002. Calliandra calothyrsus: assessing the early stages of adoption of a fodder shrub in the highlands of Central Kenya. In: Franzel, S. and Scherr, S. (2002). Trees on the farm:assessing the adoption potential of agroforestry practices in Africa. CAB International, Wallingford, UK.

Franzel, S., Phiri, D. and Kwesiga, F. 2002. Assessing the adoption potential of improved fallows in eastern Zambia. In: Franzel, S. and Scherr, S. (eds). 2002. Trees on the farm: assessing the adoption potential of agroforestry practices in Africa. CABI International, Wallingford UK.

Franzel, S., Wambugu, C., Nanok, T., Kavana, P., Njau, T., Aithal, A., Muriuki, J. and Kitalyi, A. 2007 Production and marketing of leaf meal from fodder shrubs in Tanga, Tanzania: A pro-poor enterprise for improving livestock productivity. ICRAF Working Paper No. 50. World Agroforestry Centre, Nairobi Kenya.

Franzel, S.1999. Socio-economic factors affecting the adoption potential of improved tree fallows. Agroforestry Systems 47: 305-321.

Gakuru, M., Winters, K. and Stepman, F. 2009. Inventory of innovative farmer advisory services using ICTs. FARA, Accra Ghana.

Gerhardt, K. and Nemarundwe, N. 2006. Participatory planting and management of indigenous trees: Lessons from Chivi District, Zimbabwe. Agriculture and Human Values 23: 231-243.

Gijsberg H.J.M., Kesseler J.J. and Knevel MK. 1994. Dynamics and natural regeneration of woody species in farmed parklands in the Sahel region (Province of Passore, Burkina Faso). Forest Ecology and Management 64: $1-12$.

Gilbert, R.A., Sakala, W.D. and Benson, T.D. 2002. Gender analysis of a nationwide cropping system trial survey in Malawi. African Studies Quarterly 6, No. 1. http://web.africa.ufl.edu/asq/v6/v61a9.htm. Accessed 28th May 2010.

Gladwin, C.H., Thomson, M.A., Peterson , J.S. and Anderson, A.S. 2001. Addressing food security in Africa via multiple livelihood strategies of women farmers. Food Policy 26: 177-207.

Gonsalves, J., Becker, T., Braun, A., Campilan, D., de Chavez, H., Fajber, E., Kapiriri, M., Rivaca-Caminade, J., and Vernooy, R. (eds) 2005. Participatory research and development for sustainable agriculture and natural resource management: a sourcebook. International Potato Centre, Manila, Philippines.

Gray, L. and Kevane, M. 2008. Diminished access, diverted exclusion: women and land tenure in Sub-Saharan Africa. University of California/Santa Clara University.

Guerin, I. 2006. Women and money: lessons from Senegal. Development and Change 37 (3): 549-570.

Haddad, L., Hoddinott, J. and Alderman, H. (eds). 1997. Intrahousehold resource allocation in developing countries: Models, methods and policy. Baltimore, MD: Johns Hopkins University Press.

Hakansson, T. 1986. Landless Gusii women: a result of customary land law and modern marriage patterns. Working Papers in African Studies, African Studies Programme: Department of Cultural Anthropology, University of Uppsala, Sweden.

Ham, C. 2000. The importance of woodlots to local communities, small-scale entrepreneurs and indigenous forest conservation. A case study CSIR-Enviromental/IIED/London and Pretoria. 
Harsch, E. 2001. Making trade work for poor women. Africa Recovery 15 (4): 1-16.

IFAD. 1985. Rural women in agricultural investment projects, 1977-1984. A report of findings based on an assessment study of IFAD's experience relating to women. IFAD, Rome.

IFAD. 2003. Mainstreaming a gender perspective in IFAD's operations: plan of action 2003-2006. International Fund for Agricultural Development, Rome.

IFPRI. 2007. Proceedings of the consultation on strengthening women's control of assets for better development outcomes. IFPRI, Washington DC.

ILO. 1998. Women in the informal sector and their access to micro-credit. Paper prepared for the InterParliamentary Union (IPU) Annual Conference, Windhoek, Namibia (2-11 April). ILO Employment Sector: Social Finance Unit.

Ipara, H.I. 1993. Women and agroforestry in eastern Africa: Socio-economic factors affecting participation of women in rural Kenya. African Caribbean Institute, Hanover.

Ishani, Z. 2009. Key gender issues in urban livestock keeping and food security in Kisumu, Kenya. In: Hovorka, A., de Zeeuw, H. and Njenga, M. (eds.), Women feeding cities: mainstreaming gender in urban agriculture and food security. Practical Action Publishing Ltd. UK.

Jagger, P., Pender, J. and Gebremedhin, B. 2005. Trading off environmental sustainability for empowerment and income: woodlot devolution in northern Ethiopia. World Development 33 (9): 1491-1510.

Jama, B.A. and Getahun, A. 1991. Fuelwod production from Leuceana leucocephala established in fodder crops at Mtwapa, Coast Province Kenya. Agroforestry Systems 16: 119-128.

Jama, B.A., Mutegi, J.K. and Njui A.N. 2008. Potential of improved fallows to increase household and regional fuelwood supply: evidence from western Kenya. Agroforestry Systems 73 (2): 155-166.

Kabeer, N. 2005. Is microfinance a 'magic bullet' for women's empowerment? Analysis of findings from South Asia. Economic and Political Weekly 29, 2005.

Kabutha, C. and Humbly, M. 1996. Gender concerns in agroforestry. In: People and institutional participation in agroforestry for sustainable development. (ed) Mugah J.O. 1996. Proceedings of the First Kenya Agroforestry Conference. Kenya Forestry Research Institute. Nairobi, Kenya.

Kalaba, F., Chirwa, P. and Prozesky, H. 2009. The contribution of indigenous fruit trees in sustaining rural livelihoods and conservation of natural resources. Journal of Horticulture and Forestry 1 (1): 1-6.

Kanmegne, J., Belinga, M.O., Degrande, A., Tchoundjeu, Z. and Manga, T. 2007. Gender analysis in the commercialization of Gnetum africanum/buchholzianum in Lékié division in Cameroon. Journal of Food, Agriculture \& Environment (1): 243-247.

Karaan M., Ham, C., Akinnifesi, F., Moombe, K., Jordan, D., Franzel, S. and Aithal, A. 2005. Baseline marketing surveys and supply chain studies for indigenous fruit markets in Tanzania, Zimbabwe and Zambia. World Agroforestry Centre/CPWild Research Alliance.

Karanja, G.M., Nyaata, O.Z., Mureithi, J.G. and Wandera, F.P. 1996. Fodder production under smallholder agroforestry systems. In: Muga, J.O. (ed). Proceedings of the first Kenya agroforestry conference on people and institutional participation in agroforestry for sustainable development. Kenya Forestry Research Institute, Muguga Kenya. 
Katungi, E., Klasen, S. and Smale, M. 2008. Gender, social capital and information exchange in rural Uganda. Journal of International Development 20: 35-52.

KEFRI. 1999. KEFRI Strategic Plan 1999-2004. Kenya Forestry Research Institute. Muguga, Kenya.

Keil A., Zeller M. and Franzel S. 2005. Improved tree fallows in smallholder maize production in Zambia: do initial testees adopt the technology? Agroforestry Systems 64: 225-236.

Kelly, B., Bouvet, J.M and Picard, N. 2004. Size class distribution and spatial pattern of Vitellaria paradoxa in relation to farmers' practices in Mali. Agroforestry Systems 60: 3-11.

Kimenye, L. 1998. Assessment of technology dissemination and utilization by women and men farmers. A case study of Embu and Mbeere Districts. In: Curry, J., Kooijman, M. and Recke, H, (eds), Institutionalizing gender in agricultural research institutes 5-7 October 1998. Nairobi pp. 201-204.

Kiptot, E. 2008. Dynamics of the use of Tithonia diversifolia for soil fertility management in pilot villages of western Kenya. Experimental Agriculture 44: 473-484.

Kiptot, E., Franzel, S., Hebinck, P and Richards, P. 2006. Seed and knowledge sharing: farmer to farmer dissemination of agroforestry technologies in western Kenya. Agroforestry Systems 68 (3): 167-179.

Kiptot, E., Hebinck, P., Franzel, S. and Richards, P. 2007. Adopters, testers or pseudo-adopters: dynamics of the of improved tree fallows by farmers in western Kenya. Agricultural Systems 94 (2): 509-519.

Kuntashula, E. and Mafongoya, P.L. 2005. Farmer participatory evaluation of agroforestry trees in eastern Zambia. Agricultural Systems 84: 39-53.

KWAP. 1996. A survey on gender participation in agroforestry activities in Uasin Gishu District. Kenya Wood Fuel and Agroforestry Project. Unpublished Project Report.

Kwesiga, F. and Coe, R. 1994. The effect of short rotation Sesbania sesban planted fallows on maize yield. Forest Ecology and Management 64: 199-208.

Kwesiga, F., Akinnifesi, F.K., Mafongoya, P.L., McDermott, M.H. and Agumya, A. 2003. Agroforestry research and development in southern Africa during the 1990s: review and challenges ahead. Agroforestry Systems 59: 173-186.

Kwesiga, F., Franzel, S., Place, F., Phiri, D. and Simwanza, C.P. 1999. Sesbania sesban improved fallows in eastern Zambia: their inception, development and farmers' enthusiasm. Agroforestry Systems 47: 49-66.

Leakey, R.R.B., Schreckenberg, K. and Tchoundjeu, Z. 2003. The participatory domestication of West African indigenous fruits. International Forestry Review 5(4): 338-347.

Leakey, R.R.B., Tchoundjeu, Z., Smith, R.I., Munro, R.C., Fondoun, JM., Kengue, J., Anegbeh, P.O., Atangana, A.R., Waruhiu, A.N., Asaah, E., Usoro, C. and Ukafor, V. 2004. Evidence that subsistence farmers have domesticated indigenous fruits (Dacryodes edulis and Irvingia gabonensis) in Cameroon and Nigeria. Agroforestry Systems 60: 101-111.

Lovett, P.N. and Haq, N. Evidence for anthropic selection of Sheanut tree (Vitellaria paradoxa) Agroforestry Systems 48: 273-288.

Maarse, L.M.1995. A gender differentiated study on the impact of intensive dairy farming in Kiambu, Meru, Migori, Nandi and Vihiga districts of Kenya. National Dairy Development Project, Nairobi, Kenya. 
Manda, E. 2009. Market information systems role in agricultural marketing: the case of the Malawi Agricultural Commodity Exchange. A paper for presentation at the AGRA Conference: Towards Priority Actions for Market Development for African Farmers. ILRI, Nairobi, 13-15 May 2009.

Matig, O.E. and Chikamai, B. 2009. Use and conservation of indigenous fruit tree diversity for improved livelihoods in eastern Africa. Research Report. AFREA, Bioversity and AFORNET.

Meinzen-Dick, R., Quisumbing, A., Behrman J., Biermayr-Jenzano, P., Wilde, V., Noordeloos M., Ragasa C and Beintema N. 2010. Engendering agricultural research. IFPRI Discussion Paper 00973. Environment and Production Technology Division, IFPRI.

Mithofer, D. 2004. Economics of indigenous fruit tree crops in Zimbabwe. PhD thesis. Department of Economics and Business Administration. University of Hanover, Germany.

Moore, K., Hamilton, S., Sarr, P and Thiongane, S. 2001. Access to technical information and gendered NRM practices: men and women in rural Senegal. Agriculture and Human Values 18: 95-105.

Morris, M. and Doss, C. 1999. How does gender affect the adoption of agricultural innovations? The case of improved maize technology in Ghana. Paper presented at the Annual Meeting of the American Agricultural Economics Association (AAEA), Nashville, Tennessee, August 8-11 1999.

Moser, C. 1989. Gender planning in the Third World: meeting practical and strategic gender needs. World Development 17(11): 1799-1829.

Mugo, F.W. 1999. The effects of fuelwood demand and supply characteristics, land factors, and gender roles on tree planting and fuelwood availability in highly populated areas of Kenya. PhD thesis, Cornell University, New York, USA.

Muok, B.O., Kamene, J., Kemmochi, K. and Ali, A. 1998. Socio-economic and resource survey of Kitui District. Project report. Social Forestry Extension Model Development Project. Kenya Forestry Research Institute, Kitui, Kenya.

Muok, B.O., Owuor, B., Dawson I. and Were J. 2001. The potential of indigenous fruit trees: results of a survey in Kitui District, Kenya. Agroforestry Today 12(1): 13-16.

Murithi, F. and Franzel, S. 2001. An evaluation of the economic role of cattle in the mixed smallholder farms in Embu district, Kenya. In: Wamuongo, J.W., Sitawa, J.K., Mugah, J.O. and Ayemba, J.A. (eds). From Research to agroforestry: into the next millennium. Proceedings of the National Agroforestry Research Project (NARP) Symposium held in Embu, from 8-11 December 1998.

Nair, P.K. 1989. Agroforestry systems, practices and technologies. In: Nair P.K (ed.), Agroforestry Systems in the Tropics. Kluwer Academic Publishers in cooperation with ICRAF. Dordrecht, Netherlands and Nairobi, Kenya.

Niang, A., Amadalo, B., Gathumbi S. and Obonyo C.O.1996. Maize yield response to green manure application from selected shrubs and tree species in western Kenya: a preliminary assessment. In Mugah J.O. (ed.), Proceedings of the First Kenya Agroforestry Conference on People and Institutional Participation in Agroforestry for Sustainable Development, pp 350-358. Kenya Forestry Research Institute (KEFRI), Muguga Kenya.

Niang, A., De Wolf, J., Nyasimi, M., Hanse, T., Rommelse, R. and Mwendwa, K. 1998. Soil fertility replenishment and recapitalization in western Kenya. Pilot Project Report No. 9. Regional Agroforestry Research Centre, Maseno, Kenya. 
Niang, A., Steyger, E., and Gahamanyi, A. 1992. Fodder potential of grass and shrub combination on contour bunds in Rwerere. In: Hoekstra, D. and Beniest, J. (compilers) East and Central African (AFRENA) workshop, 22-26 June 1992. Kigali Rwanda: Summary Proceedings. AFRENA Report No. 58. ICRAF, Nairobi Kenya.

Noordin, Q., Niang, A., Jama, B. and Nyasimi, M. 2001. Scaling up the adoption and impact of agroforestry technologies: experiences from western Kenya. Development in Practice 11: 509-523.

Nwonwu, F.O.C. 1996. The gender role and the future of agroforestry in Africa. In: People and Institutional Participation in Agroforestry for Sustainable Development. (ed) Mugah J. O.1996. Proceedings of the First Kenya Agroforestry Conference. Kenya Forestry Research Institute. Nairobi, Kenya.

Nyadzi, G.I., Otsyina, R.M., Banzi, F.M., Bakengesa, S.S., Gama, B.M., Mbwambo L. and Asenga, D. 2003. Rotational woodlot technology in north-western Tanzania. Tree and Crop Performance. Agroforestry Systems 59: 253-263.

Nyeko, P., Stewart, J., Franzel, S. and Barkland, P. 2004. Farmers' experiences in the management and utilization of Calliandra calorthyrsus, a fodder shrub in Uganda. Agricultural Research and Extension Network (AgREN) No. 140.

Oboler, R.S. 1985. Women, power and economic change: The Nandi of Kenya. Stanford, CA: Stanford University Press.

Obonyo, E. and Franzel, S. 2004. Biomass transfer technology experiences in western Kenya. In Proceedings of the $2^{\text {nd }}$ Kenya Forestry Scientific Conference on Recent Advances in Forestry Research and Technology Development. Kenya Forestry Research Institute (KEFRI), Muguga, Kenya. Pp 350-358.

Oduol, P., Nyadzi, G., Swai, R., Schueller, M., Gama, B., Matata, S., Mwageni, W. and Mbaruk, D. 2006. Adoption and impact of agroforestry technologies on rural livelihoods in southern Africa. Paper presented at the Second National Agroforestry and Environment Workshop Mbeya, Tanzania 14 ${ }^{\text {th }}$ March 2006. ICRAF.

Okigbo, B.N. 1980. Plants and food in Igbo culture and civilization. Ahiajioku Lecture Series. Ministry of Information, Culture, Youth and Sports. Government Press. Nigeria.

Okullo, J.B.L., Obua, J., Kaboggoza, J.S.R. and Aluma, R.W. 2003. Traditional agroforestry systems, tree uses and management in northern Uganda. Uganda Journal of Agricultural Sciences 8: 5-10.

Otsyina, R., Ramadhani, T. and Asenga, D. 1999. Rotational woodlots: an approach to mitigate deforestation and natural resource degradation in Tanzania. Faculty of Forestry and Nature Conservation Record 72: 122-130.

Paterson, R.T., Karanja, G.M., Roothart, R., Nyaata, Z. and Kariuki, I.W. 1998. A review of tree fodder production and utilization within smallholder agroforestry systems in Kenya. Agroforestry Systems 41: 181-199.

Peterman, A., Behrman J. and Quisumbing A. 2010. A review of empirical evidence on gender differences in non-land agricultural inputs, technology and services in developing countries. IFPRI Discussion Paper 00975.

Peterson, J.S. 1999. Kubweletza Nthaka: Ethnographic decision trees and improved fallows in the Eastern Province of Zambia. Gender and Soil Fertility Collaborative Research Support Programme and the International Centre for Research in Agroforestry. University of Florida, Gainsville, Florida, USA.

Phiri, D., Franzel, S., Mafongoya, P., Jere, I., Katanga, R. and Phiri, S. 2004. Who is using the new technology? The association of wealth status and gender with the planting of improved tree fallows in Eastern Province, Zambia. Agricultural Systems 79: 131-144. 
PhytoTrade Africa. 2007. A report of the impacts and achievements during 2006 of the Southern African Trade Association. Harare. Zimbabwe.

Pisanelli, A., Poole, J. and Franzel, S. 2008. The adoption of improved tree fallows in western Kenya: farmer practices, knowledge, and perception. Forest, Trees, and Livelihoods 18:233-252.

Place F., Franzel S., Noordin Q., Jama B (2004). Improved fallows in Kenya: history, farmer practice and impacts. EPTD discussion paper no. 115. Environment and Production Technology Division; International Food Policy Research Institute, 2033 K Street, N.W Washington, D.C 2006 USA.

Place, F. 1994. The role of land and tree tenure on the adoption of agroforestry technologies: a summary and synthesis. ICRAF Report. Nairobi Kenya.

Place, F., Franzel, S., de Wolf, J., Rommellse, R., Kwesiga, F., Niang, A. and Jama, B. 2002. Agroforestry for soil fertility replenishment: evidence on adoption processes in Kenya and Zambia. In: Barret, C.B., Place, F. and Aboud, A.A. (eds.), Natural resource management in African agriculture: understanding and improving current practices. CAB International, Wallingford, UK. Pp 155-168.

Poulton, C. and Poole, N. 2001. Poverty and fruit tree research: Issues and options paper. DFID Forestry Research Programme.

Quisumbing, A. 1996. Male-female differences in agricultural productivity: methodological issues and empirical evidence. World Development 24 (10): 1579-1595.

Quisumbing, A. and Pandolfelli, L. 2010. Promising approaches to address the needs of poor female farmers: resources, constraints and interventions. World Development 38(4): 581-592.

Quisumbing, A., Payongayong, E., Aidoo, J.B. and Otsuka, K. 2001. Women's land rights in the transition to individualized ownership: Implications for tree resource management in Western Ghana. University of Chicago.

Ramathani, T. 2002. Marketing of indigenous fruits in Zimbabwe. Socio-economic Studies on Rural Development 129: Wissenschaftsverlag Vauk. Kiel, Germany.

Rocheleau, D. 1991. Gender, ecology and the science of survival: stories and lessons from Kenya. Agriculture and Human Values 8: 156-165.

Rocheleau, D. and Edmunds, D. 1997. Women, Men and Trees: Gender, Power and Property in Forest and Agrarian Landscapes. World Development 25 (8): 1351-1371.

Ruiz-perez, M., Broekhoven, A.J., Aluma , J.R.W., Iddi, S., Lowroe, J.D., Mutemwa, S.M., Odera, J.A. 1997. Research on non-timber forest products in selected areas in southern and east Africa: themes, research issues, priorities and constraints. CIFOR Working Paper Bongor, Indonesia No.15.

Saito, K.A. and Wildermann, C.J. 1990. Agricultural extension for women farmers in Africa. World Bank Discussion Paper No. 103. World Bank: Washington DC.

Saka, J.DK., Swai, R., Mkonda, A., Schomburg, A., Kwesiga, F. and Akinnifesi, FK. 2004. Processing and utilization of indigenous fruits of the miombo in southern Africa. In: Rao, M.R and Kwesiga, F.R (eds.), Agroforestry Impacts on Livelihoods in Southern Africa: Putting Research into Practice. Pp 343-352. Proceedings of Regional Agroforestry Conference on Agroforestry Impacts on Livelihoods in Southern Africa. World Agroforestry Centre, Nairobi, Kenya. 
Sanchez, P.A. 1995. Science in agroforestry. Agroforestry Systems 30: 5-55.

Sanchez, P.A. 1999. Improved fallows come of age in the tropics. Agroforestry Systems 47: 3-12.

Sanchez, P.A., Shepherd, K.D., Soule, M.J., Place, F.M., Buresh, R.J., Izac, A.M., Mokwunye, A.U., Kwesiga, F.R., Nderitu, C.G. and Woomer, P.L. 1997. Soil fertility replenishment in Africa: an investment in natural resource capital. In: Buresh R.J., Sanchez , P.A., Calhoun F.G. (eds.), Replenishing Soil Fertility in Africa, pp 1-46. SSSA. Special Publication Number 51. Soil Science Society of America, Madison, WI, USA.

Scherr, S. 1995. Economic factors in farmer adoption of agroforestry: patterns observed in western Kenya. World Development 23 (5): 787-804.

Schreckenberg, K. 2004. The contribution of Shea butter (Vitellaria Paradoxa C.F Gaetner) to local livelihoods in Benin. In: Sunderland, T. and Ousseynou, N. 2004 (eds.) Forest Products, Livelihoods and Conservation. Case Studies of Non-Timber Forest Product Systems. CIFOR

Schreckenberg, K., Awono, A., Degrande, A., Mbosso, C., Ndoye, O. and Tchoundjeu, Z. 2006. Domesticating indigenous fruit trees as a contribution to poverty reduction. Forests, Trees and Livelihoods. 16: 35-51.

Schreckenberg, K., Degrande, A., Mbosso, C., Boli Baboulé, Z., Boyd, C., Enyong, L., Kanmegne, J. and Ngong, C. 2002. The social and economic importance of Dacryodes edulis (G. Don) H.J. Lam in Southern Cameroon. Forests, Trees and Livelihoods 12 (1/2): 15-40.

Shanks, E. 1990. Communal woodlots in Tanzania: farmers' response and an evolving extension strategy. London: ODI Social Forestry Network Paper No. 11C.

Sigot, A. 1995. Discourse in gender and natural resource management. In: Towards Common Ground. Gender and Natural Resource Management in Africa. Eds Sigot, A, Thrupp L.A and Green, J (1995). African Centre for Technology Studies and World Resources Institute. Nairobi Kenya and Washington DC.

Sinja, J., Karigia, J., Waithaka, M., Miano, D., Baltenwick, I., Franzel, S., Nyikal, R. and Romney, D. 2004 . Adoption of fodder legumes technology through farmer to farmer extension approach. Uganda Journal of Agricultural Sciences 9: 222-226.

Siriri, D. and Rausen, T. 2003. The agronomic and economic potential of tree fallows on scoured benches in the humid highlands of south-western Uganda. Agriculture, Ecosystem Environment 95: 359-369.

Skapa, B. 1988. When the brain is sleepy, you also sleep. Women and agriculture in Zimbabwe. A report to the World Bank, Washington DC.

Swinkels, R., Shepherd, K., Franzel, S., Ndufa, J.K., Ohlsson, E., and Sjogren, H. 2002. Assessing the adoption potential of hedgerow intercropping for improving soil fertility, western Kenya. In: Franzel, S. and Scherr, S. (eds). 2002. Trees on the farm: assessing the adoption potential of agroforestry practices in Africa. CABI International, Wallingford UK. 69-110.

Swinkels, R.A., Franzel, S., Shepherd, K, Ohlsson, E., Ndufa, J,K. 1997. The economics of short rotation improved fallows: evidence from areas of high population density in western Kenya. Agricultural Systems 55: 99-121.

Tchoundjeu, Z., Atangana, A., Asaah, E., Tsobeng, A., Facheux, C., Foudjem, D., Mbosso, C., Degrande, A., Sado, T., Kanmene, J., Mbile, P., Tabuna, H., Anegbah, P. and Useni, M. 2008. Domestication, utilization and marketing of indigenous fruit trees in West and Central Africa. In: Akinnifesi, F., Leakey, R., Ajayi, O., Sileshi, G., Tchoundjeu, Z., Matakala, P. and Kwesiga, F. (eds). 2008. Indigenous fruit trees in the tropics: domestication, utilization and commercialization. CAB International. 
Teklehaimanot, Z. 2004. Exploiting the potential of indigenous agroforestry trees: Parkia biglobosa and Vitellaria parodoxa in sub-Saharan Africa. Agroforestry Systems 61: 207-220.

Thangata, P.H. and Alavalapati, J.R.R. 2003. Agroforestry adoption in southern Malawi: the case of mixed intercropping of Gliricidia sepium and maize. Agricultural Systems 78: 57-71.

The Daily Nation. 2008. Commercial tree farming in Kenya. Web link: http://allafrica.com/stories.200805160252. html. Accessed July 2009.

Tyndall, B. and Franzel, S. 1998. Socio-economics of grevillea in the coffee land use system of central Kenya. In: Wamuongo, J.W., Sitawa, J.K., Mugah, J.O. and Ayemba, J.A (eds,). From research to dissemination: agroforestry into the next millenium: Proceedings of the National Agroforestry Research Project Symposium.

Udry, C. 1996. Gender, agricultural production and the theory of the household. Journal of Political Economy 104: (5): 1010-1046.

UNDP. 2010. Micro finance banking: providing lending services to women in Kenya. Available at:_http://www. undp.org/partners/business/resources/cs_lending.pdf. Accessed June 102010.

UNEP/GRID-Arendal. 2008. The percentage of agricultural work carried out by women compared with the percentage of female extension staff in selected African countries. UNEP/GRID-Arendal Maps and Graphics Library. 2008. Available at: http://maps.grida.no/go/graphic/the-percentage-of-agricultural-work-carried-out-by-womencompared-with-the-percentage-of-female-exte. Accessed March 11, 2010.

UNESCO 2007. UNESCO Institute for Statistics. http://www.unicef.org/sowc07/docs/sowc07_figure_2_5.pdf. Accessed October 152010.

UNESCO, 2002. UNESCO Institute for Statistics (http://www.uis.unesco.org/en/stats/statistics/ed/g_lit_afrique. jpg). Accessed October 152010.

Villarreal, M. 2002. Food insecurity, HIV/AIDS and cultural traditions among the Luo of Kenya. Rome: Population and Development Service. FAO.

Wambugu, C., Franzel, S., Tuwei, P., and Karanja, G. (2001). Scaling up the use of fodder trees in central Kenya. Development in Practice 11: 487-494.

Wangila, J., Rommelse, R. and de Wolf, J. 1999. Characterization of households in the pilot project area of Western Kenya. Research Report 12. ICRAF, Nairobi, Kenya.

Wanyoike, F. 2001. Dissemination and adoption of improved fodder trees: The case of Calliandra calothyrsus in Embu District, Kenya. MSc Thesis. University of Nairobi, Kenya.

Watson, C.L., Murray, E.C. and Just, L. (undated). Gender and the value of trees in Mutoko Communal Area, Zimbabwe. Staff Paper 96-19. Department of Rural Economy, University of Alberta, Canada.

Winrock International. 1992. Assessment of animal agriculture in sub-Saharan Africa. Little Rock, Arkansas: Winrock International Institute for Agriculture Development, Arkansas USA.

World Agroforestry Centre (2007). Trees and Cows: An Odd Combination, but a Winning Formula for African Dairy Farmers. Bulletin. World Agroforestry Centre, Nairobi, Kenya.

World Bank. 1989. Kenya: The role of women in economic development, World Bank Country Study, Washington DC, USA. 
World Bank. 1990. Agricultural growth perspective and strategy options. Vol. 3, World Bank, Washington DC USA.

World Bank. 2006. Enhancing Agricultural Innovation: How to go beyond the strengthening of research systems. Washington, DC: World Bank.

World Bank. 2007. Gender and economic growth in Kenya: Unleashing the power of women. World Bank, Washington DC. 


\section{Occasional Paper Series}

1. Agroforestry responses to HIVIAIDS in East and Southern Africa: proceedings of the HIV/AIDS workshop held in Nairobi 2003.

2. Indigenous techniques for assessing and monitoring range resources in East Africa.

3. Caractérisation de la biodiversité ligneuse dans les zones en marge du desert: manuel de procedures.

4. Philippine landcare after nine years: a study on the impacts of agroforestry on communities, farming households, and the local environment in Mindanao.

5. Impact of natural resource management technologies: fertilizer tree fallows in Zambia.

6. Les haies vives au Sahel: état des connaissances et recommandations pour la recherche et le développement .

7. Improved Land Management in the Lake Victoria basin: final Report on the TransVic project.

8. Intégration du genre dans la mise en oeuvre d'un: programme agroforestier au Sahel: guide pratique des chercheurs.

9. Swiddens in transition: shifted perceptions on shifting cultivators in Indonesia.

10. Evidence for impact of green fertilizers on maize production in sub-Saharan Africa: a metaanalysis.

11. Can organic and resource-conserving agriculture improve livelihoods? A meta-analysis and conceptual framework for site-specific evaluation.

12. The impact of fodder trees on milk production and income among smallholder dairy farmers in East Africa and the role of research. 


\section{Our Vision}

A rural transformation in the developing world as smallholder households strategically increase their use of trees in agricultural landscapes to improve their food security, nutrition, income, health, shelter, energy resources and environmental sustainability.

\section{Our Mission}

To generate science-based knowledge about the diverse roles that trees play in agricultural landscapes, and use its research to advance policies and practices that benefit the poor and the environment. 


\section{About the Occasional Paper series}

The Occasional Paper is produced by the World Agroforestry Centre to disseminate research results, reviews and synthesis on key agroforestry topics. The manuscripts published in this servies are peer reviewed.

Copies can be obtained from the Communications Unit or from the Centre's website on www.worldagroforestry.org

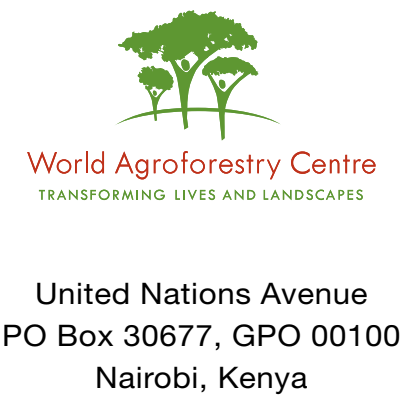

Tel: +254207224000 , via USA +1 6508336645

Fax: +25420 7224001, via USA +1 6508336646

Email: worldagroforestry@cgiar.org 